Silvana Souza Pessoa

\title{
REFLEXÕES SOBRE GRUPOS E UM ESTUDO DE CASO UTILIZANDO O DISPOSITIVO DO CARTEL.
}

Dissertação apresentada a Faculdade de Educação da Universidade de São Paulo como parte dos requisitos para a obtenção do grau de mestre em Educação. Área de Concentração: Psicologia e Educação.

Orientador: Prof. Dr. Rinaldo Voltolini

São Paulo

2008 
Silvana Souza Pessoa

\section{REFLEXÕES SOBRE GRUPOS E UM ESTUDO DE CASO UTILIZANDO O DISPOSITIVO DO CARTEL.}

Dissertação apresentada a Faculdadede Educação da Universidade de São Paulo como parte dos requisitos para a obtenção do grau demestre em Educação. Área de Concentração: Psicologia e Educação.

Orientador: Prof. Dr. Rinaldo Voltolini

Aprovada em:

Banca Examinadora:

Prof. Dr.

Instituição:

Assinatura:

Prof. Dr.

Instituição:

Assinatura:

Prof. Dr.

Instituição: Assinatura: 
SUMÁRIO

\begin{tabular}{|c|c|}
\hline 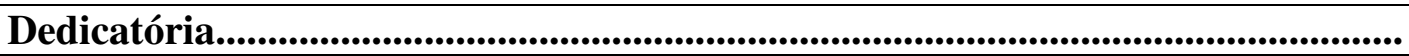 & 3 \\
\hline Agradecimentos................................................................................................................ & 4 \\
\hline 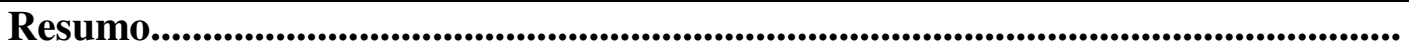 & 5 \\
\hline 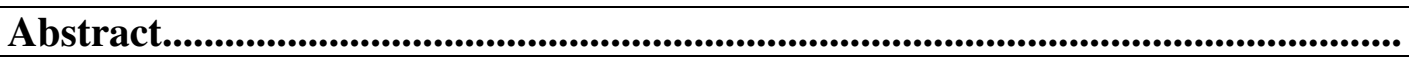 & 6 \\
\hline Introdução & 8 \\
\hline Capítulo 1. Introdução ao tema dos grupos: um olhar psicanalítico..................... & 12 \\
\hline 1.1. Breve histórico sobre o estudo dos grupos................................................ & 14 \\
\hline 1.2. Grupo: um lugar de fomentação de imagens.................................................. & 20 \\
\hline 1.3. Grupo: uma rede de significantes........................................................... & 25 \\
\hline 1.4. Grupo: uma estrutura topológica - um dispositivo.......................................... & 32 \\
\hline Capítulo 2. Algumas propostas de funcionamento em grupo.................................. & 42 \\
\hline 2.1. Grupo operativo - uma invenção para operar mudanças.......................... & 45 \\
\hline 2.2. Grupos de trabalho - abertura para novas possibilidades....................... & 54 \\
\hline 2.3. Cartel - uma proposta para transmissão...................................................... & 68 \\
\hline Capítulo 3. Uma experiência com cartel e adolescentes no campo educacional. & 76 \\
\hline 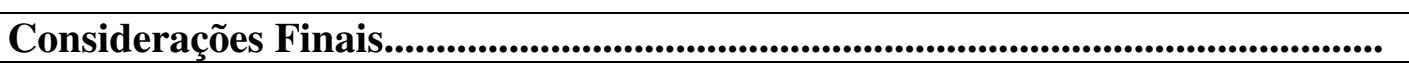 & 100 \\
\hline 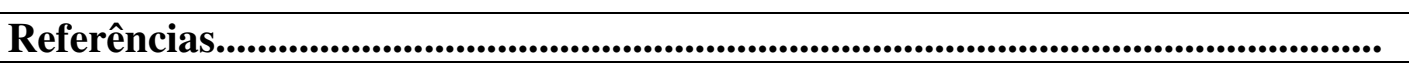 & 122 \\
\hline 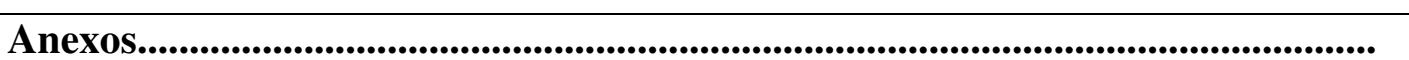 & 123 \\
\hline
\end{tabular}


À vida e seus milhões de desafios e impasses que tive que enfrentar com amizade, criatividade e com a qual tenho aprendido a responder cada vez mais com muito estudo, paciência e generosidade. 


\section{AGRADECIMENTOS}

Aos meus pais, já falecidos, que com sacrifício e dedicação, souberam me dar as ferramentas necessárias para construir muito do que faço no mundo.

Ao meu marido e colega, Climério Brito, parceiro leal que me acompanha desde a faculdade nesse percurso de construção de uma vida familiar e profissional. Ao nosso filho Guilherme, que hoje me inspira e apóia nos meus projetos, especialmente esse do mestrado.

A todos da minha família e amigos, pela paciência e pelo respeito que tiveram com meu distanciamento e ausências muitas vezes necessários, especialmente a Miriam Tavares, sogra-amiga, que me apoiou com escuta e idéias nas fases mais difíceis e a Sandra Sarué, forte incentivadora e fornecedora de boas indicações para efetivar a publicação desse trabalho.

Aos meus professores e educadores, que sempre insistiram para que eu dissesse "para que vim ao mundo". Recentemente, ao meu orientador Rinaldo Voltolini e aos colegas da banca Christian Dunker e Ângela Vorcaro, que me fizeram refletir, produzir e enxergar coisas que passaram despercebidas.

A Angélia Teixeira e Jairo Gerbase que me deram coragem para pensar, falar e desconstruir muita coisa que foi construída e que não valia - ou não vale - a pena e aos colegas dos Fóruns do Campo Lacaniano pelas referências e insight.

Aos meus colegas de grupo de estudo do Lepsi, que me fizeram ver os limites da Psicanálise e colocá-la na sua posição de parceria e não superioridade em relação aos demais saberes produzidos por outros campos.

Aos meus colegas coordenadores e professores da Acbeu, aos alunos que já tive enquanto professora de Inglês durante a graduação em Psicologia e aos meus alunos de licenciatura da Faculdade de Educação da Ufba, enquanto professora substituta da disciplina Psicologia Aplicada à Educação.

A todos aqueles com quem já fiz um trabalho de cartel, em especial, a Beatriz Oliveira (mais-um), Dominique Fingerman, Silvia Barile e Reinaldo Grilo que toparam fazer comigo um cartel sobre os cartéis, fundamental para escrita dessa dissertação.

Por fim, a toda equipe de alunos e educadores do Centro Juvenil, especialmente a Pe. Mauro, diretor geral, que franqueou o seu espaço sem interferir na parte prática do projeto e a Therezinha, diretora pedagógica, agradeço todo apoio, solidariedade. 
PESSOA, S.S. Reflexões sobre grupos e um estudo de caso utilizando o dispositivo do cartel. Dissertação de Mestrado, Faculdade de Educação, USP, São Paulo, 2008, número total de pp. 118.

\section{RESUMO}

O presente trabalho pretende estudar o cartel, órgão de base da Escola lacaniana, fora de uma instituição psicanalítica, comparando seu funcionamento às demais formações de grupos existentes, e se destina aos educadores e aos psicanalistas. O tema grupo é investigado nas obras de Freud, Anzieu e outros estudiosos da psicanálise. A primeira parte é dedicada ao estudo do conceito de grupo e das diversas formações coletivas espontâneas existentes, a partir da visão psicanalítica. A segunda parte analisa as propostas de grupos formados para a execução de um trabalho, desenvolvidas por Pichon, Bion e Lacan. $\mathrm{O}$ funcionamento, o papel da autoridade e os objetivos desses grupos - grupos operativos, grupos de suposição básica, de trabalho e o cartel - são investigados nos textos dos próprios autores. A terceira parte é dedicada à reflexão sobre a realização de um trabalho com cartéis, em um centro educacional na cidade de São Paulo, Brasil, com a participação de jovens entre 11 a 14 anos. Nela são realizadas algumas reflexões sobre o funcionamento desse dispositivo e a comparação com as outras formas de grupo estudadas. Finalmente, procede-se à reflexão da conseqüência deste estudo para a educação e a psicanálise, concluindo-se que esse estudo é relevante para educadores e psicanalistas que trabalham nos grupos para transmitirem as especificidades dos seus campos.

Descritores: educação, psicanálise, transmissão, grupos e cartel. 
PESSOA, S.S. Reflections on groups and a case study using the cartel device. Master's Thesis. School of Education, University of São Paulo, 2008, total pages: 118.

\begin{abstract}
The purpose of this thesis is to study the cartel, the basic working unit of the Lacanian School, outside a psychoanalytical institution, and compare its mechanisms to those of the other existing group formations. This study is aimed primarily at educators and psychoanalysts. The group theme is investigated in the works of Freud, Anzieu and other psychoanalysis experts. The first section is dedicated to the study of the concept of group and of the several spontaneous collective formations from the psychoanalytical viewpoint. The second section analyzes the proposals developed by Pichon, Bion and Lacan involving groups formed for the production of a piece of work. The operation, the role of authority and the goals of such groups - operational groups, basic supposition groups, work groups and the cartel - are reviewed through the texts written by the authors themselves. The third section is dedicated to a reflection on the case study using the cartel, which was carried out in an educational center in São Paulo, Brazil, with the cooperation of teenagers aging 11 to 14. There are also some thoughts on the operation of such device and a comparison with the other group forms studied. Finally, a reflection follows on the consequence of the present study for education and psychoanalysis to conclude that such study is relevant for educators and psychoanalysts who use groups to impart the specific skills and knowledge of their own fields.
\end{abstract}

Main words: education, psychoanalysis, conveyance, groups and cartel. 


\section{INTRODUÇÃO}

Estudiosos da Psicanálise são freqüentemente convocados a responder inquietações com pedidos de orientações técnicas, modelos de intervenção, para lidar com o imprevisível, o desconhecido, com aquilo que foge à regra no campo da educação. "O aluno não aprende aquilo que lhe ensino". O desconhecido da Pedagogia que faz o pedagogo entrar em crise, pois abala as suas crenças, toca a sua impotência e o faz demandar respostas aos especialistas do comportamento ou da mente e aos psicanalistas. O que fazer quando o aluno não aprende ou não produz a contento? A quem responsabilizar?

A Psicanálise, como um campo de saber em estreita interface com a Educação, tem sido utilizada como referência teórica e prática com o intento de resolver algumas dessas questões. As respostas têm variado ao longo do tempo: de apresentações do sistema teórico, passando por intervenções profiláticas, até ofertas de métodos de ajustamento do aluno a escola. Apenas mais recentemente temos visto com maior freqüência estudos com investigações das variáveis presentes no campo educacional em interface com o psicanalítico, onde a presente pesquisa se situa.

Na década de 1920, no período pós-guerra, época em que a Psicanálise foi introduzida no Brasil, como um dos efeitos do movimento modernista, a mesma foi tomada não como um instrumento terapêutico, mas como um sistema teórico passível de ser aplicado em diversas áreas do saber, particularmente à Educação. Os textos dedicados ao tema destinavam-se na sua quase totalidade a uma apresentação teórica de conceitos psicanalíticos objetivando familiarizar o educador com o jargão específico da área, particularmente aquelas formulações teóricas dedicadas às crianças, que começavam a surgir no continente europeu, de forma a favorecer a aprendizagem e proporcionar-lhes condições mais favoráveis para um desenvolvimento saudável, por intermédio de uma educação menos coercitiva e que levasse em conta as suas características. (ABRÃO, 2006, p.236).

Um segundo período, após a introdução da Psicanálise no Brasil, foi caracterizado pela utilização desta como instrumento profilático. Isso estava em conformidade com os ideais eugênicos vigentes na Psiquiatria brasileira da época. Não se tratava unicamente de atribuir aos pais e aos professores a função precípua de agentes profiláticos de futuras manifestações da doença mental, por intermédio de uma educação infantil guiada por princípios psicanalíticos. Mas, o objetivo principal destes trabalhos era “o de promover a prevenção da 
doença mental, através da compreensão e da assistência às manifestações sintomáticas da criança em idade escolar". (ibid. p. 238).

A análise desses dois momentos evidencia que a Psicanálise foi tomada no meio educacional brasileiro, no início até a metade do século passado, como instrumento prático destinado a promover o ajustamento do aluno na escola e não como um recurso para a compreensão da subjetividade da criança, muito menos a subjetividade do professor. Nessa forma de abordagem, excluía-se a categoria infantil, enquanto uma categoria atemporal, inconsciente, que influencia a conduta humana na criança ou no adulto, e a substituía por uma concepção mais pragmática, desenvolvimentista, relacionada à criança como indivíduo.

Atualmente as pesquisas, em contrapartida, provavelmente ajustando o vetor de análise, passaram a oferecer formas de intervenção no meio educacional e a considerar mais o aspecto relacional do professor e aluno; da mesma forma passaram a contemplar a noção de infantil, e a sustentar uma prática que busque a formação integral do professor que detenha o conhecimento teórico de Psicanálise e experiências pessoais que permitam aproximá-lo de suas vivências inconscientes, de suas experiências infantis recalcadas. (ibid. p.239).

Verificamos que grande parte das pesquisas neste campo concentra-se na relação dual, na relação do professor com o aluno ou no estudo individual de alunos para buscar compreensão ou modelos de intervenção, para lidar com o imprevisível, o desconhecido, com aquilo que foge a regra no campo da educação. Algumas apontam para uma resistência em lidar com o tema, concluindo que existe a necessidade de mudança paradigmática da relação professor como o aluno para a relação do professor como parte integrante do grupo-classe (SILVA, 2000).

Por outro lado, também no lado psicanalítico, precisamos pensar a transmissão como uma estrutura, como um laço particular e não apenas como uma relação dual (VOLTOLINI, 2007) e colocar em campo alguns pontos específicos da sociabilidade exigida na transmissão da Psicanálise. (DUNKER, 2004). Desde os tempos de Freud, os psicanalistas se organizam em grupos, instituições, sociedades e mesmo quando não participam dessas promovem encontros, colóquios, organizam grupos de estudos para transmitir a Psicanálise. Deste modo, é legitimo afirmar que um estudo das forças presentes nos grupos interessa aos dois campos, o educacional e o psicanalítico.

O que move o presente estudo é tentar verificar os pontos de aproximação existentes nesses dois campos quanto aos meios coletivos utilizados para transmissão: seminários, grupos de pesquisa, grupos de estudo e o cartel. Desse movimento surgiram algumas questões 
secundárias: O que pode ensinar o cartel, um pequeno grupo inventado por Lacan para transmissão da Psicanálise, aos educadores? O que o diferencia dos grupos existentes na educação: das formações grupais espontâneas: as "panelinhas", os bandos, etc. e dos grupos de estudo, grupos operativos, grupos de trabalho e de suposição básica? O cartel só pode se inscrever em uma instituição psicanalítica? O cartel poderia acontecer com pessoas mais jovens?

Partiremos para esse estudo, em um campo desconhecido, com a clara convicção de que não queremos oferecer mais uma forma de intervenção no meio educacional ou institucionalizar um procedimento. Esperamos apenas que esse estudo possa trazer algumas reflexões sobre os grupos, de forma geral, e sobre o cartel, de forma específica, para poder avançar um pouco mais o saber sobre esse desconhecido da pedagogia e da Psicanálise, a relação do professor com o grupo-classe, ou do analista nos grupos-transmissão.

Para dar conta deste intento, realizaremos esse estudo em três tempos: começaremos analisando o conceito de grupo priorizando uma leitura psicanalítica do tema; em seguida, abordaremos três propostas de grupos desenvolvidos por Pichon, Bion e Lacan; e finalizaremos a investigação com um estudo de caso, um trabalho com cartéis proposto para estudantes de 11 a 14 anos de um Centro Educacional na zona oeste da cidade de São Paulo.

$\mathrm{Na}$ primeira parte, apresentaremos o tema tomando como ponto de partida o conceito, as resistências e as principais questões levantadas por Freud e outros autores para o estudo dos grupos. Também apresentaremos as diferentes formas de abordá-lo e as metáforas a ele atribuídas. Veremos que muitas pesquisas encontradas nesse campo estão saturadas de grupalidade, ou seja, tratam o grupo tal como um aparelho psíquico individual, que pensa, sente e desenvolve. Muitas se referem aos indivíduos e não ao sujeito do inconsciente entendido como efeito de linguagem.

Isso nos obrigará a fazer um recorte de alguns pontos da teoria lacaniana que entende a persona como uma máscara e introduz no seu lugar o conceito de sujeito, que só pode ser do inconsciente, diferenciando-o do individuo. Nesse ponto do estudo, introduziremos a noção de constituição de sujeito tomando como referência os conceitos de real, simbólico e imaginário. Trabalharemos as identificações com essa abordagem e utilizaremos os referencias da topologia e da física para fundamentar que os grupos, tal como os sujeitos, não pensam, sofrem, agem, mas estão sujeitos aos efeitos de linguagem e da cultura.

Na segunda parte, trabalharemos os grupos operativos, desenvolvidos por Pichon; nos grupos de trabalho e suposições básicas apresentadas por Bion; e a criação de Lacan os cartéis. Extrairemos de cada autor estudado os seus principais pressupostos e referenciais 
teóricos relacionados ao nosso tema, advertidos que apesar de terem a mesma origem, a psicanálise freudiana, nem sempre tiveram o mesmo olhar para os mesmos fenômenos.

Nossa opção de trabalharmos com três autores com práticas distintas de grupo nos obrigará a realizar alguns descentramentos. Nem todos têm o mesmo olhar sobre os mesmos fenômenos. Para reduzir as possíveis distorções advindas, evitaremos referências secundárias e recorreremos às fontes diretas, os escritos dos próprios autores.

Trabalharemos nas brechas e na composição discursiva que utilizavam. Dialogaremos utilizando os referenciais psicanalíticos, que serão apresentados no primeiro capítulo, destacando os pontos que mais nos chamam atenção e que podem contribuir para reflexões nos dois campos: educacional e psicanalítico.

Na última parte, faremos um estudo de caso utilizando o cartel com jovens de 11 a 14 anos que freqüentam um Centro Juvenil na zona oeste da cidade de São Paulo, no turno oposto ao que freqüentam a escola. Neste capítulo, descreveremos o trabalho realizado e, minimamente, alguns pontos importantes relativos à adolescência. Priorizaremos nesse capítulo fazer as reflexões possíveis sobre a colocação desse dispositivo em campo.

Desejamos, com esse estudo, contribuir para a prática daqueles que trabalham com grupos, especialmente para os educadores que têm que lidar com grupos: professores, coordenadores ou orientadores educacionais que trabalham com formação de outras pessoas

Também tentaremos oferecer coordenadas mínimas sobre outros funcionamentos de grupos para colegas psicanalistas que, além de conduzirem análises, são responsáveis pela transmissão, já que ministram seminários, participam de grupos e cartéis.

No último capítulo, buscaremos registrar algumas conseqüências que esse estudo nos apresentou. 
INTRODUÇÃO AO TEMA DOS GRUPOS: UM OLHAR PSICANALÍTICO 


\section{CAPÍTULO 1. Introdução ao tema dos grupos: um olhar psicanalítico.}

\subsection{Breve histórico sobre o estudo dos grupos.}

O tema que nos propomos a estudar é bastante vasto e não se esgota em complexidades e interfaces com o social, o que nos obrigará a circunscrever apenas alguns pontos da questão. O recorte que propomos é parcial, não tem a intenção de considerar o todo dos grupos, mas apenas alguns efeitos de grupo e a relação dos seus membros com a liderança, o ideal do Eu, em linguagem freudiana, ou, com a autoridade do grupo revestida de conteúdos imaginários e narcísicos. Utilizaremos um ou outro termo ao longo deste trabalho e tentaremos evitar uma visão de "grupalidade", ou seja, entender os grupos como um "ser" que reproduz as estruturas psíquicas dos indivíduos.

Encontramos neste percurso poucos trabalhos acadêmicos que tratavam da psicanálise e os grupos na educação como forma de transmissão, particularmente nenhum que tomasse o cartel como objeto de estudo em comparação com outros grupos de orientação psicanalítica. Constatamos, com alguns colegas (ABRÃO, 2006; SANTOS, 2003; SILVA C. 2000), que grande parte das pesquisas neste campo concentra-se na relação dual, na relação do professor com o aluno ou no estudo individual de alunos para buscar compreensão ou modelos de intervenção, para lidar com o imprevisível, o desconhecido, com aquilo que foge à regra no campo da educação. A grande maioria oferece pouca reflexão sobre a interação do professor com grupo de alunos, sua posição e suas intervenções como parte de um grupo.

Nessa parte verificaremos alguns possíveis motivos dessa resistência e faremos um recenseamento dos tipos de agrupamentos existentes, quanto à sua organização e ao tipo de liderança, partindo da análise feita por Silva (2000) nas obras de Freud, Anzieu, Bion e Pichon. Esses três autores contemporâneos, apesar de freudianos na origem, fundamentam suas teses na psicanálise kleiniana, na psicologia do Eu, orientação distinta da leitura que Lacan faz da psicanálise freudiana, autor que introduzimos neste estudo para apresentarmos o cartel, uma outra proposta de funcionamento grupal. Isso nos obrigou a lançar mão de outro inventário sobre grupos, desta vez feito por Costa (1989), por estar em maior conformidade com a teoria lacaniana, que pretendemos utilizar como principal operador de leitura nesse trabalho.

Primeiramente alguns estudiosos de grupo (NERI 1999; ANZIEU 1993) supõem que a origem da dificuldade esteja relacionada à etimologia da palavra, que data do século XVII, mas a sua utilização, tal como a utilizamos hoje, é bem recente. Grupo vem do idioma italiano 
groppo ou gruppo, e era utilizada como termo técnico das Belas Artes para referir-se a "vários indivíduos, pintados ou esculpidos, que compõem um tema". Seu uso literário se deu com Molière, que o fez passar para a linguagem corrente como "um conjunto de elementos, uma categoria de seres e objetos" (ANZIEU, ibid. p.43). Foi apenas no século XVIII que a palavra grupo assumiu o significado de reunião de pessoas e só no século XIX foi utilizada como termo técnico na matemática. Duas linhas de pensamento presentes, em maior ou menos medida da formulação de todas as teorias de grupo estudadas. (SILVA C. opus.cit. p.8).

A noção de grupo, enquanto reunião de pessoas, está presente em duas linhas de forças: a noção de vínculo e a noção de círculo, duas marcas de interdependência entre os participantes. A noção de vínculo conota o grau de coesão existente entre os elementos do grupo, especialmente na relação com os líderes, lutando por um ideal comum, por exemplo; a noção de círculo, é tomada como reunião de pessoas, representando igualdade de posições, tal como os Cavaleiros da Távola Redonda se sentavam sem distinção de lugares, para que todos estivessem em igualdade perante o Rei e Cristo. Mas sabemos que, se a noção de desigualdade está mais evidenciada em formações escolares ou de seminários, quando os alunos sentam em fileira, a igualdade entre os membros não está presente em todos os grupos, mesmo quando as pessoas sentam-se em círculo.

Quanto à outra linha de pensamento, a noção de matemática, a mesma entende os grupos como conjuntos, ou seja, em ambos há a possibilidade de existência de diferentes tipos de elementos (pessoas); diferentes números de entidades (vários grupos grandes ou pequenos); existência de regras e a possibilidade de serem explícitas ou não (grupos de professores, de torcedores de um determinado time de futebol, de músicos, de psicanalistas); maneira como as regras podem ser combinadas de forma associativa, cumulativa ou não (todos devem se atualizar com outros grupos, pagar taxas, critérios de inclusão de novos membros, etc.) e por fim, que todo elemento de um conjunto deve conter o seu inverso (um grupo de professores tem, necessariamente, um outro grupo que lhe complementa, o de alunos; para cada grupo de chefes, há o grupo dos subordinados, etc.).

Nós acrescentaremos - e fundamentaremos mais adiante - a essas duas linhas de pensamento, outras metáforas fortemente relacionadas a idéias de grupalidade e carregadas de forte conteúdo moral: a do grupo como um "organismo vivo" ou como uma "máquina", por um lado, e outras mais próximas da geometria, topologia ou física. Podemos citar alguns modelos, tais como a figura da estrela, composta de triângulos isósceles, retirados da geometria, a noção de dispositivo, conceito da física, trabalhado por Foucault, e a de nó 
borromeano, retirado da topologia, para entendermos o funcionamento dos grupos e dos cartéis, que sofrem efeitos do simbólico, imaginário e real.

Antes de estudarmos essas duas linhas de pensamento, o grupo como um organismo vivo e um grupo organizado discursivamente, é preciso dizer algo mais sobre a resistência ao estudo de grupos. Todos os estudos referentes a este tema, na vertente psicanalítica, partem da obra Psicologia das massas e análise do eu e passam pelos seus textos sociológicos Totem e Tabu; O futuro de uma ilusão; O mal-estar na cultura e Moisés e o monoteísmo, mas nenhum destes textos freudianos aborda o grupo diretamente.

Todos têm por objeto a cultura; a civilização; o social; a sociedade; as massas; a coletividade; as instituições, etc., mas não o grupo. Só em um breve momento, em Psicologia das massas e análise do eu, Freud acena para o que poderia ser um esboço de caracterização de um pequeno grupo. (COSTA, opus cit. p.57).

Esse pequeno grupo a que Freud se referia, sabemos que é a família e seus substitutos imediatos e que esse modelo, com devidas restrições, servem para a compreensão do que caracteriza a experiência humana, mas não necessariamente as pessoas nos grupos, menos ainda, pensamos, os grupos no campo da educação. Ainda são poucos são os estudos neste campo (ABRÃO, 2006; SILVA, 2000; NERI, 1999; COSTA 1989).

Alguns estudiosos do grupo, na vertente psicoterápica, apontam outras hipóteses para a resistência ao trabalho em grupo, que podemos tentar transpor para o campo estudado e submeter à apreciação: o grupo como ameaça à liberdade individual:

\footnotetext{
Se há uma resistência à noção de grupo, essa resistência deve se articular a fenômenos psicológicos precisos. (...) a única forma de grupo admitida é o grupo de "amigos". O grupo de trabalho ou o grupo institucionalmente imposto são percebidos como um ataque e uma ameaça a liberdade individual. (...). (ANZIEU. opus cit. p.43).
}

Esse autor argumenta que todo grupo onde não se conhecem as pessoas que fazem parte dele e, onde não se é conhecido, onde os papéis sociais ficam às sombras, grupos como nos grupos de diagnóstico ou de expedições - poderíamos acrescentar, primeiro dia de aula, participação em conferências, seminários, grupos de formação de professores; a situação de grupo desperta angústia, desperta uma imagem de fragmentação indefinida da pessoa e, antes de tudo, do corpo, "como um espelho de múltiplas facetas lhe refletindo a imagem de si próprio deformada e repetida ao infinito". (ibid. p.44).

Quem sou eu? Eis o questionamento que a situação de grupo exerce sobre cada membro. E essa questão é para o homem a mais difícil de colocar e assumir. Convém formar a hipótese de que essa imagem do corpo ameaçada explica a resistência a viver em grupo, a trabalhar em grupo e mesmo ao conceito de grupo. (ibid.). 
Investigações conduzidas por psicossociólogos e apresentadas na "Avaliação dos resultados da formação" no. 3, da AFAP, em 1961, (ibid. p.49) põem em evidência que, para a maioria das pessoas, a noção de grupo é inexistente, o grupo é efêmero, dominado pelo acaso. Representa-se geralmente o grupo como uma alienação da personalidade, da liberdade, da dignidade. (ibid, p. 29). O avanço dos métodos de grupo é tomado como uma ameaça para o equilíbrio do indivíduo e para a ordem da sociedade. É inevitável que o grupo, lugar privilegiado do desejo, mobilize mecanismos de defesa do Eu entre chefes de empresas, dirigentes de escolas, professores, psicólogos e até entre psicanalistas, conclui Anzieu (ibid. p.49). Seria esse a razão da pouca quantidade de trabalhos de grupos, com o professor como integrante do grupo-classe? Um mecanismo de defesa? Uma ameaça a sua autoridade? Como a teoria psicanalítica poderia ajudar na compreensão desses fenômenos?

Inicialmente, é importante ressaltarmos um pouco da história. A psicanálise foi tomada não como um instrumento terapêutico, mas como um sistema teórico passível de ser aplicado em diversas áreas do saber, particularmente à educação na década de 1920, no período pós-guerra, época em que a psicanálise foi introduzida no Brasil, como um dos efeitos do movimento modernista. A grande maioria dos trabalhos dedicados ao tema, destinava-se na sua quase totalidade a uma apresentação teórica de conceitos psicanalíticos objetivando familiarizar o educador com o jargão específico da área, particularmente aquelas formulações teóricas dedicadas às crianças, que começavam a surgir no continente europeu, de forma a favorecer a aprendizagem e proporcionar-lhes condições mais favoráveis para um desenvolvimento saudável, por intermédio de uma educação menos coercitiva e que levasse em conta as suas características. (ABRÃO, opus cit. p.236). Favorecer a aprendizagem e proporcionar-lhes condições mais favoráveis para um desenvolvimento saudável ou forma de conhecer para dominar?

Quanto à história da psicanálise em grupos, constatamos que as idéias mais importantes da psicanálise sobre grupo foram elaboradas em um período muito curto, de aproximadamente apenas 50 anos, (NERI, 1999, p.29) desde a publicação de Totem e Tabu por Freud (1912-13), passando pela Psicologia das Massas e Análise do Eu até Experiências com Grupos (1961) de Bion. Vários autores que estudam grupos e psicanálise afirmam que Freud nunca deixou de ter interesse neles. Muitos admitem tudo que Freud diz como sendo uma teoria válida para o cultural e o social (MOSCOVICI, 1985; ENRIQUEZ, 1983), mas a concordância de vários não quer dizer que elas sejam indiscutíveis (COSTA, 1998). Concordamos com a ressalva feita por Costa, já que entendemos a cultura como conjunto de eventos humanos institucionalizados, que não pode ser dedutível das leis do inconsciente, 
nem redutível às mesmas leis; mas compreendemos que o fragmento abaixo, tenha aberto precedentes para esses mal-entendidos e para as idéias de grupalidade.

\begin{abstract}
É verdade que a psicologia individual relaciona-se com o homem tomado individualmente (...) contudo, apenas raramente e sob certas condições excepcionais, a psicologia individual se acha em posição de desprezar as relações desse indivíduo com os outros. Algo mais está invariavelmente envolvido na vida mental do indivíduo, como um modelo, um objeto, um auxiliar, um oponente, de maneira que, desde o começo, a psicologia individual, nesse sentido ampliado mas inteiramente justificável das palavras é, ao mesmo tempo, também psicologia social. (FREUD, 1921/1974, p.91).
\end{abstract}

Para Costa, Freud não tem uma teoria consistente sobre o grupo ou sobre o social, (opus. cit. p.102). Ele fundamenta, argumenta e justifica nesse trabalho, mas também constata que para Freud sem o social, nada de psiquismo individual. Para este autor, Freud se interessou em saber como o indivíduo, através das suas determinações psíquicas, concebe, pensa e fantasia o social. Muito diferente de uma pesquisa saturada pela "grupalidade", que se importava em entender o que o grupo "pensa" ou "sente".

Para Costa, e para nós também, o que há de essencial no estudo dos grupos é a discussão do imaginário. Destacamos a importância para nós, especialmente, porque o cartel, objeto do nosso estudo, foi concebido na sua estrutura e funcionamento, para barrar os efeitos imaginários de grupo - precisamos entender e tentar demonstrar como isso acontece. Outro ponto fundamental, para Costa e para nós também - no nosso caso com restrições quanto à análise do social, já que este não é o objetivo deste trabalho -, é olhar para as coisas como elas se apresentam para constatar o que for possível; da mesma forma como Freud constatou, observando e investigando, que quando o homem não está no social, no registro simbólico, ele fica entregue às forças pulsionais, ao real.

\footnotetext{
Este homem é o homem entregue às forças cegas da libido, como na Moral Sexual Civilizada; é o homem funcionando em regime de onipotência narcísica, assassinando e sendo assassinado, antes que instituições mais fortes venham freá-lo, como em Totem e Tabu; é o homem do estado de pânico narcísico, como na massa sem lei, nem rei, na debandada de Psicologia das Massas; é o homem inerme e desamparado, por sua impotência biológica, como no Futuro de uma Ilusão; é o homem, enfim, ameaçado de destruição pela potência da pulsão de morte, como no Mal-estar na Cultura, etc. (ibid. p. 103).
}

A preocupação principal de Freud nos textos destacados acima se referia às multidões, ao estudo das massas para fornecer as bases à psicologia psicanalítica. A questão principal, que Freud tentou responder era: “qual a relação que mantém o grupo unido?” Ponto de partida para a elaboração da teoria das pulsões e das relações de identificação no grupo (NERI, opus cit. p. 30), análise do real e do imaginário para nós. Outra questão importante para Freud “estava em saber se o complexo de Édipo poderia ser considerado um fator de base para a 
psique do indivíduo, assim como para a estrutura do grupo" (ibid.). Indagação que encontra resposta positiva em Freud, mas não necessariamente em outros autores, como Bion, que "afirma não ser possível compreender os fenômenos de grupo, tomando como exemplo Édipo e as ligações familiares; ao contrário, o foco da sua atenção é dirigido para níveis mais primitivos da vida mental”. (ibid. p.30). Discussão em que não pretendemos entrar neste trabalho.

Destacamos apenas que, no inventário de Costa sobre grupos, ele afirma que Bion foi um dos poucos psicanalistas, estudiosos de grupo, que não tentará reduzir o grupo às estruturas psíquicas individuais, tais como Anzieu e Käes fizerem. Anzieu, por exemplo, "repete quase ponto por ponto os achados da teoria psicanalítica". Ele conceituou cinco organizadores inconscientes da vida grupal: fantasia, imago, fantasias originárias, complexo de Édipo, e imagem do corpo próprio, organizadores interdependentes na busca de satisfação imaginárias da necessidade do grupo, que exprimem a "natureza grupal do inconsciente", aproximando-se da idéia de Käes, em que o inconsciente é estruturado como um grupo e o grupo é um "ser", uma imagem reflexa do psiquismo individual..

Para Costa e alguns autores, Franco (1986), O'Donnell (1984) e Pontalis (1968) as idéias de grupalidade, transposições de idéias psicanalíticas para o domínio do grupo, são inconsistências que geraram mal-entendidos, Para eles Bion e Pichon, tiveram uma postura diferenciada. Isso nos interessa, particularmente já que os colocaremos para dialogar com Lacan na parte prática desta pesquisa. Pontalis, citado por Costa, um dos autores mais críticos da inconsistência das teorias de grupo, afirma que os teóricos de grupo pecaram por não entenderem que, do ponto de vista psicanalítico, o que importa no grupo é a sua dimensão imaginária. (opus cit, p.44). Problema que não tiveram os três psicanalistas destacados nesta pesquisa.

Todos três partem de Freud, que centrou as suas observações em agrupamentos espontâneos como a multidão, analisada por Gustave Le Bon (1855), tipo menos elaborado de organização grupal, mais sujeito aos efeitos imaginários de grupo tais como: desaparecimento da consciência ou responsabilidade, contágio, fascinação pelo líder ou ideais que favoreçam a sugestão, redução da capacidade intelectual, sentimento de onipotência, sentimentos muito simples ou muito exagerados, submissão ao poder mágico das palavras ou falta de anseio pela verdade. (FREUD, 1921/1980).

A multidão é descrita como a reunião de um grande número de pessoas, que possuem motivações semelhantes para estarem no mesmo lugar, mas não concordaram anteriormente em reunir-se. Embora haja proximidade física, não há integração efetiva entre eles. Essa 
característica de "falta de integração" exclui a multidão do nosso estudo, já que temos o interesse em analisar o funcionamento de grupos menores no que diz respeito aos efeitos imaginários e discursivos, particularmente os de idealização do líder no grupo, transposto, para o professor no grupo-classe, o coordenador dos grupos de trabalho ou operativos e o mais-um dos cartéis na produção escrita de um texto.

Freud interessou-se por aquele que poderia ser colocado no lugar de ideal, enquanto objeto de amor, ou de ameaça, enquanto ocupando um lugar hostil. De Totem e Tabu a Psicologia das Massas ele opera um deslocamento nesta figura. Do pai temido e ameaçador ao líder amado, que resultará no entendimento de que existem sentimentos ambivalentes presentes nas relações das crianças com seus pais e que podem ser transpostos para qualquer um que ocupe lugar de autoridade. Assim, professores, líderes podem vir ocupar o lugar do Ideal do Eu, expressão utilizada para definir um objeto libidinal, investido como imagem do que o sujeito pode vir a ter.

Em Psicologia das Massas e análise do Eu Freud nos apresentou três tipos de identificação: ao pai, ao Ideal do Eu, encarnado pelo líder; a identificação amorosa; a histérica, facilidade de colocar-se em qualquer situação, identificada pelo vazio que causa o desejo; e, por fim, ao traço unário: um traço significante qualquer em uma outra pessoa, que pode ser o bigode do analista, os óculos do professor, o olhar do coordenador, etc.

Veremos no capítulo seguinte que Lacan lê a identificação com o traço unário, a um significante qualquer, como "identificação com o desejo da histérica" e a distingue da "identificação histérica", apontada por Freud. Assim, o conceito de identificação, na topologia Lacaniana, deixa de lado a identificação ao pai e a identificação histérica. , mais personalistas, apoiadas no registro imaginário; e destaca a Identificação ao desejo, ao objeto a, que nada mais é que aquilo que falta ao Outro, no simbólico, onde a função da fala é a mola superior. Como entender isso no grupo?

\subsection{Grupo: lugar de fomentação de imagens.}

Entramos no campo do desejo e do imaginário. O Ideal só existe porque entra na dialética do desejo do outro. Como? Uma mãe investe na imagem do seu filho aquilo que ela gostaria que ele fosse, mas também ele é amado tal como é. Entre a imagem ideal, o ideal do $E u$ - promessa a ser alcançada, representando o sujeito como falta, "aquilo que ela gostaria que ele fosse" - e a imagem real, existe uma distância que obriga o Eu Ideal a se modificar, faz com que o sujeito invista tempo nas relações com o outro e ao mesmo tempo trás a 
perspectiva de morte, já que o ideal é algo ausente, inexistente, uma imagem tal como a da lua refletida nas águas de um lago.

Voltemos ao professor, lugar idealizado para uns e desvalorizado para outros, que comprova que estamos no campo das imagens, das fantasias que são únicas e particulares, que refletem nas atividades, na forma de estar no mundo e agir nele. Estudos recentes (SILVA, M. 2005, p.159-60), realizados em diversos países, mostram que a maioria de professores iniciantes, que ainda não completaram três anos de ensino, têm dificuldade em manter a disciplina nas salas de aula, motivar os alunos e a lidar com as diferenças individuais entre eles. Os professores iniciantes apresentam dificuldades para avaliar os trabalhos dos alunos; para relacionarem-se com os pais, com seus alunos e com a comunidade. (GUARNIERI, 1996, p. 13-4).

As conclusões tiradas deste estudo é que no curso de formação de docentes os alunos lêem e discutem sobre o tema "disciplina na sala de aula", mas não praticam a ação de manter a classe disciplinada como se fossem professores. (...) o aprendizado que advém da observação é intelectual, e não é prático (SILVA, M. opus.cit. p.159-60). De um outro modo, a prática se adquire quando se está no exercício da profissão, ou seja, quando os professores iniciam o trabalho com o grupo. Nós diríamos que a questão pode ser colocada além da prática. Certamente quando os jovens professores ocupam o lugar da autoridade da classe, o lugar de ideal, sofrem os seus efeitos: serem amados, respeitados ou temidos. Isso não é sem efeitos para eles e se reflete na prática. Entretanto, a "ação de manter a classe disciplinada", implica na análise de um outro campo, a transmissão da lei, da linguagem, portanto, do simbólico.

Mais uma ressalva precisa ser feita antes de darmos tratos a essa questão. $\mathrm{O}$ estudo da influência da autoridade na produção dos grupos nos levaria muito distante do que nos propomos para esse estudo a comparação do cartel com o funcionamento dos outros grupos de orientação psicanalítica e a sua possibilidade de acontecer fora de uma Escola Lacaniana. Manter uma classe disciplinada não faz parte do nosso objeto de estudo, todavia entender o conceito de transmissão da lei, entendida enquanto simbólico, e o papel da autoridade em um grupo, além da posição imaginária que ocupa para os alunos, faz parte das questões que esse estudo coloca. Dito isso, passemos à análise dessa questão.

A posição de autoridade, que aprendemos com Freud e olhando a cultura e as civilizações, é fundamental para entendermos os grupos. É o desejo do outro que constitui o Eu narcísico do sujeito, o imaginário, mas é o Outro, a herança cultural, a linguagem que constitui o sujeito. Em uma linguagem lacaniana o Outro é a linguagem, o tesouro de 
significantes, responsável pela formação dos seus ideais e pela censura dos seus impulsos hostis, portanto pela transmissão da disciplina, que faz a psicanálise nos faz postular que a disciplina não se impõe, se transmite, pelo efeito de castração, limite, inerente a própria linguagem.

Vimos que Freud interessou-se pelos fatores de coesão dos grupos, idealização e ameaça, ambos com a mesma fonte, o narcisismo. Estudou as multidões e as grandes instituições como o Exercito e a Igreja com esse fim. Tomou como referência o estudo realizado por Le Bon, mas também sabemos que ele utilizou o trabalho de McDougall (1920) para tratar dos grupos pequenos, considerados como mais elaborados e, portanto, mais amadurecidos, isto é, que estabelecem suas relações de modo mais produtivo no tocante ao alcance dos objetivos. (FREUD 1921/1974, p.109).

Tratar o grupo como passível de amadurecimento, tal como uma pessoa, um "ser", estaria incluído nas abordagens de grupalidade? Seria possível pensar em uma condição ideal ou isso faz da fantasia de alguns autores sobre os grupos?

Tomamos o estudo de onde partimos nessa pesquisa (SILVA C., 2000), para fazermos essa análise. Ele foi realizado com o objetivo de secretar contribuições para o campo educacional e conclui que é necessário o conhecimento da dimensão grupal para o manejo adequado de situações no âmbito pedagógico, postulando que há necessidade de uma mudança na relação dual do professor aluno para o professor grupo-classe. A autora chega a essas considerações a partir de um levantamento feito de várias formas de grupos em três eixos teóricos: psicanalítico, psicodramático-humanista e topológico-institucionalista, nos quais focamos nossa abordagem no primeiro eixo. No corpo da pesquisa emerge uma expectativa:

[...] que esse estudo venha possibilitar o desenvolvimento do grupo de alunos, ajudando-os, por meio de atividades pedagógicas, alcançar estágios mais amadurecidos de seu funcionamento como grupo. Isto é, o professor visando a atingir efeitos produtivos em seu trabalho pedagógico, pode criar condições para que o grupo de alunos vá se comprometendo cada vez mais com os seus próprios objetivos, estabelecendo cada vez mais a noção do "nós" que engendra a coesão grupal, deixando de ser um agrupamento para tornar-se um grupo primário e, porque não, futuramente um grupo secundário. Mas para isso, o professor deve, primeiro, perder o medo de fortalecer o grupo de alunos. (ibid. p. 15)

Antes de analisarmos a questão formulada anteriormente, cabe apresentar os tipos de grupos mencionados nessa citação para entendermos como se daria esse "amadurecimento".

As definições foram extraídas deste estudo e estão baseadas no inventário sobre grupos feito por Anzieu. Sabemos que este autor, apesar de levar em consideração o imaginário, dimensão que realmente importa no estudo de grupos. Entretanto, Anzieu o fez na 
transposição do aparelho psíquico individual para o aparelho psíquico grupal. O grupo com o sonho, ou seja, realização de desejo e de fantasias, e seus mecanismos de formação lhe são análogos. Tal como nos sonhos os grupos fantasiam para se defenderem contra a as ameaças que sentem: angústia, frustração, culpa. Essa é a sua tese.

Para ele o grupo é o lugar de fomentação de imagens, funciona com fantasias inconscientes comum a todos, o que dá a impressão de unidade e cria a ilusão grupal. "Quando um grupo funciona eficazmente, é também uma representação imaginária que lhe permite encontrar solidariedade e eficiência. Não há grupo sem imaginário. Pode-se expulsar um imaginário, ele é substituído por um outro" (ANZIEU, opus cit. p.46). Quanto à organização ele os dividiu em quatro tipos: bandos, agrupamentos, grupos primários e grupos secundários.

O primeiro grupo descrito, o bando, pode ser encontrado nos diversos agrupamentos sociais. Ele é definido como a reunião de pessoas para realizações de atividades diversas, como lazer ou trabalho, nem sempre em relação direta com a criminalidade. Essa forma de agrupamento caracteriza-se pela busca do semelhante com afinidades ideológicas, mesmos valores morais e status. Uma identificação entre pessoas que pode ser inconsciente, mas que traz prazer, pois, diminui a tensão gerada pela tentativa de adaptação a uma nova situação.

Para o autor analisado, o bando dá apoio e suporte afetivo ao indivíduo: quanto mais insegura e carente a pessoa, maior facilidade para fazer parte dele. Uma forte característica é que nele inexiste uma meta clara e seu único objetivo é a busca do semelhante, a busca de estarem juntos. "É freqüente ocorrer de os indivíduos acentuarem características ou comportamentos que os identifiquem ainda mais com o bando, como o modo de falar, vestir, etc. Tal mudança é conhecida como "efeito de grupo" (SILVA C. opus cit, p.11) e é encontrada na escola em forma de "panelinhas".

\footnotetext{
No bando vou procurar a presença de outros que não exercem sobre mim nem constrangimento, nem crítica, de outros que me são semelhantes. A imagem implicada aqui é a minha própria imagem, mas multiplicada, reforçada, justificada pelo que os outros são; é uma imagem narcísica tranqüilizadora. (ANZIEU, opus cit. p.45).
}

Ele defende que o professor não deve se tornar um terapeuta de grupos, mas afirma que a tarefa do psicólogo, do psicanalista, é ser permeável a essas representações imaginárias, de modo a poder nos grupos nos quais vive e pelos quais é consultado, elucidá-las e conduzir o próprio grupo a elucidá-las, na medida em que essas representações são obstáculo a seu funcionamento. Os que atuam nos grupos e instituições sabem que essa não é uma tarefa fácil. O reconhecimento das fantasias inconscientes para um indivíduo, grupo ou cultura, é sempre 
uma operação difícil e dramática. Seria interessante verificar como esse conhecimento seria transposto para a relação do professor no grupo-classe.

O segundo tipo de organização de grupo é o agrupamento. Palavra derivada de grupar, agrupar, constitui-se quando indivíduos se reúnem de modo sistemático e freqüente em torno de objetivos comuns, mais ou menos conscientes, mas que não são assumidos como próprios. Como não são assumidos como tal, pode haver uma certa passividade na busca dos mesmos. (SILVA C. p. 11), Grupo que a autora define como sendo os grupos-classe, já que os alunos não tomam para si os objetivos da escola e do professor.

Os grupos primários ou pequenos, formados por um número reduzido de participantes, possibilita um contato maior entre os integrantes, favorece uma postura mais ativa, em que cada indivíduo assume os objetivos efetivamente como seus e do grupo. Essa proximidade traz a noção de coletividade, do "nós", possibilitando o estreitamento dos laços afetivos e da interdependência e solidariedade intragrupal. Há uma organização por meio de normas, crenças, rituais, definições de papéis e um forte controle social existente entre seus participantes.

\begin{abstract}
Existe a preocupação de preservação física e idealizada do grupo, de modo que seus participantes têm comportamentos que favorecem o relacionamento e a manutenção do grupo. Destaca-se a importância da comunicação entre seus membros, sem que nenhum funcione como intermediário, há contato direto entre todos. Por essa razão, essa categoria também é conhecida como grupo face-to-face. (ibid. p.12).
\end{abstract}

Por fim, os grupos secundários, cuja característica principal é a de serem regidos por instituições jurídicas, econômicas, políticas, etc. Esses tipos têm um sistema social organizado para alcançar objetivos claros. O relacionamento entre os participantes é caracterizado por ser racional, impessoal e com certa formalidade, o que aparece, inclusive, na definição clara dos papéis sociais dos indivíduos. Interessam nesses tipos de grupo apenas segmentos da personalidade do individuo, decorrendo disso uma diminuição da exigência de lealdade e solidariedade no grupo, presentes no grupo primário.

Retomemos a análise proposta de "amadurecimento" do grupo de alunos versus medo que o professor tem do "fortalecimento" desse grupo. Entendemos que essa visão está em conformidade com uma abordagem grupalidade da questão que entende o grupo e não as

\footnotetext{
1 "Nós", primeira pessoa do singular, nos remete à concepção matemática dos grupos, á topologia, aos "nós" borromeanos, compostos de três instancias: o imaginário, o simbólico e o real e enlaçados pelo sintoma. Nos grupos verificamos a influência do imaginário, traço comum de identificação que une os membros do grupo, o simbólico, traço discursivo transmitido pela linguagem e o real, a morte, que não tem representação. O sintoma, ou o Nome-do Pai, traço da constituição neurótica, atam essas três rodinhas. Na psicose, que falta essa amarração, os laços se desmontam a um apelo a essa montagem discursiva. Examinaremos mais de perto esta propriedade borromeana, quando estudarmos o cartel no capítulo 2.
} 
pessoas no grupo que podem amadurecer, mudar de atitude: o professor pode entender a dinâmica de forças atuantes no grupo, sem entendê-las como fortalecer ou enfraquecer o grupo. Entendemos que esta é uma visão desenvolvimentista, muito embora seja uma visão criticada nas considerações finais; "apontamos, ainda, a apropriação individualizante que o campo educacional faz das teorias psicológicas, dando destaque apenas para seu aspecto desenvolvimentista, engendrando uma concepção de sujeito que dificulta - ou mesmo impede - pensar o grupo, pensar o coletivo, ainda melhor, pensar o aluno como sujeito relacional e concreto" (ibid. p.187).

Pensamos que a autora deslocou essa visão desenvolvimentista individualista que criticava propondo ao campo educacional um estudo do professor como parte do grupo para melhor lidar com as questões surgidas em sala de aula. Nós propomos uma análise pela via do desejo e do discurso para entender as situações de grupo, sem adotar nenhuma visão desenvolvimentista, pois, o sujeito da psicanálise, tal como entendemos não é "relacional e concreto"; para este reservamos os termos pessoa ou indivíduo. Para nós o sujeito é o do inconsciente, que não pensa, não age não se desenvolve. Ele apenas aparece nos intervalos do discurso, nos lapsos, nas manifestações sintomáticas. Como transpor isso para os grupos?

\subsection{Grupo: uma rede de significantes.}

Vejamos, Apollon psicanalista e professor de filosofia da Universidade de Laval em Quebec, escreve um artigo que trata as gangues, grupos, com forte componente imaginário, cujo "laço social" é composto só de homens,, dentro desta lógica discursiva. O estudo realizado pelo autor aponta para a existência de uma relação imaginária entre os membros do grupo, com um ponto em comum: a repressão de parte da sexualidade feminina, se não, o próprio desejo feminino como desejo proibido. Constatamos na cultura que esses grupos tornam-se facilmente patogênicos ou delituosos, um lugar privilegiado para o exercício das perversões.

A interpretação possível para tanta agressividade, proposta pelo autor, é a de que muitas vezes esses grupos escondem a impotência dos seus membros, manifestada em insulto às mulheres, que metaforizam o desejo do Outro, ou na demanda de se tornar pai de um menino, para ser reconhecido como homem, metaforizando a potência sexual. Nesse caso, o nome do progenitor é transmitido como, e com, a linguagem e, esse pilar, composto da acusação e censura à feminilidade, é a condição fundamental para a produção do sentido histórico e social de masculinidade, entendida, portanto, como uma transmissão discursiva. 
(APOLLON, 1994, p. 205-8). Parece estranho pensar os grupos como transmissão discursiva, mas Apollon justifica.

Qualquer discurso instituído não produz um objeto específico, por exemplo, a psicologia como discurso, não produz um fenômeno parapsicológico ou psiquismo, para ser referenciada como consistente no campo experimental. Assim, a psicologia como discurso instituído, constitui uma ligação entre os psicólogos. Esse discurso institui uma identidade social, ao invés e no lugar de uma identidade simbólica que seria sustentada pelo Nome-doPai. De outro modo, alguém é psicólogo ou cientista, antes de ser Sr. ou Sra. Fulana de Tal. Isso garante identidades sócio-históricas e profissionais e garante reconhecimento pelos outros, como exemplificado no discurso das gangues.

Esta é uma outra forma de analisar a questão dos grupos, um olhar psicanalítico para os grupos que compartilhamos: a possibilidade de leitura de fenômeno de grupo pela sua existência lógica, simbólica, discursiva, transmitida pela linguagem. Nesta perspectiva, um grupo não é um "ser" que age, pensa e pode se desenvolver, mas as pessoas que o integram são afetadas pela discurso do Outro, um discurso instituído pela linguagem e a cultura, e a atividade ou tarefas em comum de um grupo só pode ser conduzida pelas fantasias imaginárias de cada um.

Algumas metáforas, fantasias imaginárias do grupo, para examinarmos essas diferentes perspectivas de grupo. Vimos no início deste capítulo que a noção de círculo e vínculo eram presentes em quase todas as formações de grupo. Anzieu afirma que a noção de círculo, referente à Távola Redonda dos cavaleiros do Rei Artur, que imprime uma noção de igualdade entre todos os elementos, é um símbolo que se aproxima da imagem materna, "uma grande boca, de onde sai o discurso coerente do grupo ou uma multiplicidade de bocas que se entredevoram, ou um sexo feminino, buraco central que a palavra do presidente-falo penetra e fecunda; se em fileira, tipo escolar, tem por objetivo inconsciente impor a prevalência da imago paterna". (ibid. p. 171).

Ele também se refere ao grupo como um "envelope vivo" que faz as pessoas ficarem juntas, com uma membrana de dois lados, uma voltada para a realidade interior dos membros do grupo, o si-mesmo, que fundamenta a realidade imaginária dos grupos "é o continente dentro do qual uma circulação fantasmática e identificatória vai se ativar entre as pessoas" (ibid. p.XVIII) e uma realidade externa, física e social, voltada para outros grupos. Enquanto esse envelope não se constituiu é apenas um agregado humano, não há grupo. Também reduzido à sua trama, o envelope grupal é um sistema de regras, uma rede que contem pensamentos, palavras, ações. 


\begin{abstract}
Essa rede, que contém palavras, pensamentos e ações, permite o grupo a constituir um espaço interno (que proporciona um sentimento de liberdade na eficiência e que garante a manutenção das trocas intra grupo) e uma temporalidade própria (compreendendo o passado de onde tira a sua origem, e um futuro onde projeta cumprir suas metas). Reduzido à trama, o envelope grupal é um sistema de regras, aquele que opera por exemplo em todo seminário, religioso ou psicossocilógico. Desse ponto de vista toda a vida do grupo está presa em uma trama simbólica: é ela que o faz perdurar. Eis, todavia, uma condição necessária, mas não suficiente. Um grupo onde a vida psíquica morreu pode mesmo assim sobreviver.. De seu envelope, a carne via sumiu, só resta a trama". (ibid.).
\end{abstract}

Nessas duas metáforas, a de círculo e de envelope, defendidas pos Anzieu, percebemos o caráter imaginário "do" grupo, ainda percebemos "o" grupo, como entidade, um bloco único: um "envelope vivo" que faz as pessoas ficarem juntas, "é o continente dentro do qual uma circulação fantasmática e identificatória vai se ativar entre as pessoas, (...) enquanto esse envelope não se constituiu é apenas um agregado humano, não há grupo". Para Anzieu, o simbólico existe, é uma condição necessária, mas não suficiente. Existem outras formas de olhar os grupos, outras metáforas possíveis que vamos também analisar.

Encontramos em Néri uma outra metáfora. Para ele o símbolo que melhor representa o grupo é a estrela; “em cada uma das suas pontas, um membro do grupo, cada um deles destacando certos aspectos da comunicação; todos, porém, encontram-se ligados, a partir de um ponto central que unifica e centraliza as idéias" (opus cit. p. 48). Segundo ele esse ponto central pode ser conhecido por todos ou ainda se encontrar em fase de definição. Ele faz uma analogia ao conto islâmico, da tradição sufi, "O elefante no escuro", que mostra como falar das coisas sem ter uma visão global.

Um elefante foi entregue como presente à noite ao rei de um país cujos habitantes nunca haviam visto o animal. O bicho foi imediatamente colocado em um pavilhão e alguns curiosos entraram no pavilhão para fazer um reconhecimento do presente. Para não serem vistos, decidiram não levar nenhuma lanterna e fazer o reconhecimento apalpando e tocando o animal. Claro que faziam descrições distintas de acordo com as partes que haviam tocado e apalpado: tromba, perna, rabo e orelha. Sem juntar as percepções para fazer a imagem do objeto, saíram com diferentes idéias do que se tratava o presente. O grupo, para Neri, visto na sua disposição como uma estrela, pode ser considerado como "um convite para valorizarmos a presença do confronto entre diferentes vértices para a obtenção de um conhecimento, o que para uma só pessoa seria muito difícil de obter". (ibid.).

De fato nenhuma pessoa pode ter pontos de vista tão diversos sobre um mesmo assunto; cada membro representa um ponto de vista diferente, e cada um pode usufruir do ponto de vista do outro, além do mais cada um vê a realidade através da sua janela psíquica, a 
sua fantasia, mas essa troca nem sempre acontece. Mesmo os advertidos, os psicanalistas ou educadores psicanaliticamente orientados, em muitas situações de grupo, apresentam uma intolerância com as idéias divergentes. Parece que todos precisam ter uma mesma e velha opinião formada sobre tudo. Por que isso acontece? Tratemos um pouco da noção de vínculo antes de arriscarmos uma tentativa de resposta.

A palavra vínculo, "grau de coesão entre as pessoas de um grupo", bond em inglês, tem duplo sentido. É uma ligação, mas também uma servidão, um limite imposto. O termo refere-se a tudo que ata, liga, une ou refreia, mas também admite traduções por laço, liame, nó, compromisso, obrigação, servo ou escravo e, em sua forma plural, grilhões. "Nenhuma criança poderia evoluir sem a confiança e amparo que provém da crença de autoridade de seus pais; no entanto, na vida adulta, muitas vezes se teme que a busca dos benefícios emocionais da autoridade transforme as pessoas em dóceis escravos" (SENNET, 2001, p. 14).

Vimos anteriormente que essa ambigüidade, dirigidas às figuras de autoridade pode ser entendida pelos conceitos de alienação e separação, constitutivos do sujeito. A criança muito prematura precisa se alienar ao significante que recebe do Outro, da cultura, inicialmente representada pela figura materna, para depois separar-se, já que este Outro não tem todos os significantes que possam lhe representar, há sempre algum que falta. Nesta dialética, o Nome-do-Pai, representante da lei, encarnado em um outro, que pode ser o pai, faz limite a essa relação dual e alienante. A psicanálise tomou como metáfora deste processo constitutivo à dialética do senhor e do escravo de Hegel. Vamos a ela.

Logo no inicio do capítulo, Hegel escreve que o ser humano inteiro "só existe ao ser reconhecido". Isso implica em um "processo de reconhecimento mútuo". O senhor depende do escravo para a produção do seu prazer. É verdade que pode matá-lo de fome, maltratá-lo, isso lhe trará um prazer sádico, mas é aquilo que o escravo produz, o trabalho feito por ele, seja um casaco, uma refeição, que fornece os meios de prazer para o senhor. A pessoa escravizada toma consciência do que realmente é, através da consciência do prazer que o seu trabalho produz no senhor. Para Hegel esse é o primeiro passo para sair da servidão. Depois deste, quatro outros estágios de liberdade acontecem, marcados por crises da autoridade, que ocorrem através da descrença naquilo em que antes se acreditou.

Esses quatros estágios são o estoicismo, o ceticismo, a consciência infeliz e a consciência racional. Sennet nos ajuda a defini-los de forma clara (ibid. p.172). Os escravos começam retirando-se do mundo para seus próprios pensamentos, no estágio estóico. No ceticismo, estágio seguinte, ele volta-se para o mundo e ainda um servo obediente descrê do papel que desempenha e da superioridade moral do senhor. A consciência infeliz internaliza 
esse conhecimento cético sobre uma relação social: existem um senhor e um escravo em todo ser humano; Hegel chama essa consciência infeliz de "consciência do eu como um ser de natureza dupla, meramente contraditório". Na consciência relacional essa triste cisão que cada pessoa vê em si mesma, é vista nos outros, esse conhecimento volta a se socializar.

\footnotetext{
Hegel chama de relacional esse último estágio da liberdade porque, nesse momento, o sujeito pode perceber e agir com os outros de acordo com objetivos comuns; já não há necessidade de lutar contra os outros pelo reconhecimento, pois a própria consciência desenvolveu-se a ponto de o sujeito saber que suas divisões internas são divisões que existem em toda humanidade. Hegel também chama essa consciência racional e dotada de propósitos de estado 'absoluto' de liberdade (...): ‘do absoluto cabe dizer que é essencialmente um resultado, que só no fim ele é o que realmente é'. (ibid. p. 173).
}

Nesses dois últimos estágios, diz Sennet, o senhor perde o poder sobre o seu escravo, não porque o escravo tome seu poder ou o derrube, mas porque ele se tornou uma pessoa diferente, aprendeu a lidar de uma maneira não competitiva com o senhor e isso obriga este último a modular o seu próprio comportamento. Dito isto, voltemos à pergunta anterior, que poderia ser reformulada para: por que as pessoas temem escutar as opiniões distintas das suas e precisam segurar-se nas suas velhas crenças? Por que o trabalho em grupo se torna tão ameaçador e fonte de resistência para muitos?

Vimos no inicio deste capítulo que ele é fonte de angústia, um espelho fragmentado do Eu, também vimos com Freud e Le Bon que a química dos grupos tem uma força que fazia que as pessoas se "perdessem em si mesmas". Com Hegel entendemos a dialética da relação de um com o outro. A liberdade é essa experiência de cisão, o reconhecimento que há um senhor e um escravo dentro de cada um: "somente admitindo esse fato poderão os seres humanos vir, um dia, a ter a esperança de serem mais do que duelistas. A liberdade existe, finalmente, quando o reconhecimento que dou a você, nada retira de mim”. (ibid. p. 174)

Entretanto a história está cheia de elementos de intolerância. Na Idade Média, por exemplo, quando a fé cedia suas forças e lugar para a razão, dando início ao iluminismo, um dos seus principais representantes, Voltaire defendia a pessoa humana e os seus direitos básicos à vida, à liberdade e à justiça. Sabemos que os iluministas combateram a tirania dos governadores absolutistas, refutando a tese de que o poder real emanava de Deus. Voltaire tentou garantir a liberdade de pensamento e ficou conhecido pela sua celebre frase: "Não concordo com nenhuma de tuas palavras, mas defenderei até a morte o teu direito de dizêlas". Por causa das suas idéias, foi perseguido e exilado.

Em 1945, quando Lacan esteve em Londres para uma estadia de cinco semanas, afirmava que saia de um "encantamento" deletério, pela irrealidade que os franceses haviam 
vivido, para entrar em contacto com um "outro mundo", a Inglaterra completamente destruída no pós-guerra.

\begin{abstract}
A guerra me havia deixado um vivo sentimento da forma de irrealidade em que a coletividade dos franceses a tinha vivido de ponta a ponta. (...). Refiro-me, antes, em cada um há um desconhecimento sistemático do mundo, a refúgios imaginários em que, psicanalista, eu só podia identificar no grupo, então às voltas com uma dissolução verdadeiramente assustadora de seu status moral, as mesmas modalidades de defesa que o indivíduo utiliza na neurose contra a sua angústia, e com um sucesso não menos ambíguo, tão paradoxalmente eficaz quanto elas, e selando assim, pobres de nós, um destino que se transmite por gerações. (LACAN,1947/2003, p.106).
\end{abstract}

Neste período, Lacan entrou em contacto com o trabalho terapêutico de grupos desenvolvido por Bion com soldados de guerra, relatado anteriormente. Ele demonstrou muito interesse na proposta de "alguém em que (...) brilha a chama da criação",. Achou que ele lançou um "novo olhar sobre o mundo, que não se pode furtar facilmente". Qual seria esse "novo olhar"? Vale a pena nos determos nesse ponto, pela importância que esse "olhar" tem para o nosso estudo sobre os grupos e, em particular, sobre o cartel.

No fragmento acima, vimos um Lacan impactado com os efeitos destrutivos da guerra. Ele identificava no grupo os mesmos mecanismos de defesa utilizados com sucesso não menos ambíguo: o "desconhecimento sistemático", "refúgios imaginários", "mesmas modalidades de defesa", que o indivíduo utiliza na neurose contra a sua angústia, selando assim, pobres de nós, um destino que se transmite por gerações. Na nossa leitura, é o "malestar da civilização", "transmitido" por gerações, para o qual a psicanálise lacaniana propõe "uma intervenção" ética em todos os campos, dentre eles, o educacional, que nos concerne nesse estudo. (VOLTOLINI, 2001; MELLO, 1995).

Há sempre dissonância entre uma pessoa e outra. Sempre existirá diferença nas formas com que diversas pessoas percebem o mundo e vivem os vínculos com pares e com a autoridade. Nem todas estão no mesmo estágio de libertação da submissão apontada por Hegel, e "só no fim ele é o que realmente é", as relações com a autoridade "não são como as esculturas de Brancusi, puras e sólidas, mas ambíguas e constantemente mutáveis, variando de uma pessoa para outra”. (SENNET, opus cit, p. 22). Ambigüidade, dissonância, impossibilidade nas relações que podemos extrair da própria linguagem, nos ensinou Freud e mais ainda Lacan.

Podemos extrair a impossibilidade de relação, de dizer a verdade toda, de atingir um ideal, etc., da própria estrutura da linguagem, ou seja, um significante remetendo a outro, infinitamente, em uma cadeia discursiva a cada vez que se coloca a questão, "mas o que isso quer dizer?', ou o “o que pensa disso?". Sob o efeito do recalque, alguns significantes são 
esquecidos, outros distorcidos, pelo processo de condensação e deslocamento, outros trocados. Em cada momento que isso acontece, dizemos que foi uma manifestação do inconsciente, lapsos, chistes, atos falhos, com a terminologia freudiana, ou um efeito de sujeito, com o léxico lacaniano",um significante que representa um sujeito para outro significante". (LACAN, 1964/1998, p. 854).

O sujeito só aparece no intervalo ente o primeiro significante e o segundo, por isso é um efeito. Como sujeito de linguagem, ele está ligado ao ser vivo, mas ele não é uma pessoa. Talvez fosse preciso inventar um significante novo para isso que acontece nos intervalos, entre duas palavras, por que a palavra sujeito, na nossa língua, ao menos, é aquele que pratica a ação em uma frase. Enquanto, o sujeito do inconsciente, não predica nada, não pensa, não age. É efeito de linguagem, aparece de repente e quando aparece já deixa de ser inconsciente.

\footnotetext{
Qual seja, a maneira certa de responder à pergunta 'quem está falando?', quando se trata do sujeito do inconsciente. Pois essa resposta não poderia provir dele, se ele não sabe o que diz e nem sequer que está falando, como nos ensina a experiência inteira da análise. (ibid. p.815).
}

Mesmo tendo sugerido a "criação" de um significante novo para esse sujeito do inconsciente, sabemos que isso não resolveria o paradoxo inerente à própria linguagem, paradoxos da lógica do inconsciente construídos pelas propriedades banais dos significantes e que favorecem a emergência desse sujeito descrito por Lacan nos intervalos. Vejamos, a lógica clássica respeita certos princípios: o da identidade: $\mathbf{A}=\mathbf{A}$; e o da não contradição: $\mathbf{A}$ não pode ser, ao mesmo tempo, não $\mathbf{A}$.

A psicanálise demonstra que a linguagem não aceita esses princípios. Ela pode aceitar a desordem. O significante, sua unidade mínima, pode suportar a coexistência de signos contraditórios numa cadeia a ser constituída na sincronia; e a ordem mais indestrutível associativa que se manifesta da diacronia. (LACAN, 1960/1998, p. 664-5). Podem-se fazer essas afirmações baseado na linguiística e na Interpretação dos Sonhos onde Freud demonstra que o sonho não aceita esses limites e expõe sua tese várias vezes na sua obra, especialmente quando trata dos mecanismos de formações do inconsciente como na Psicopatologia da Vida Cotidiana. A psicanálise faz a subversão da lógica clássica e nela pode-se escrever ao mesmo tempo que $\mathbf{A} \neq \mathbf{A}$ e $\mathbf{A}=\mathbf{A}$. De um outro modo, ela admite que um significante não seja idêntico a si mesmo, $\mathbf{A} \neq \mathbf{A}$.

Neste ponto é que endentemos que a psicanálise pode ajudar aos que trabalham com grupos. A equivocação faz parte da linguagem, não é "má vontade" do aluno. Não precisamos ir muito longe para extrairmos exemplos. A palavra "irado" pode ser, ao mesmo tempo, "nervoso" e "bacana". Não há laço natural entre significante e significado, nem entre os 
significantes e as coisas. Propriedade da linguagem, atribuída a arbitrariedade dos signos, para os lingüistas. Para os lingüistas isso se deve por causa da arbitrariedade do signo, para os lacanianos pela contingência, pelo o que para de se não se escrever. Algo, um significante, uma idéia, de repente entra na cadeia discursiva, o que faz com que um organize sua própria rede de vias significantes.

\subsection{Grupo: uma estrutura topológica - um dispositivo.}

No seminário sobre a Identificação, (1962), Lacan utilizou diversas figuras tridimensionais, retiradas da topologia, como instrumento para demonstrar a tese freudiana do inconsciente estruturado como uma linguagem. Lacan, apesar de sua formação em medicina, era um ótimo aluno de matemática. Talvez isso justifique a sua capacidade para fazer demonstrações com matemas e com a topologia.

O Toro, estrutura topológica mais simples, foi utilizado para falar da natureza do sujeito próprio ao inconsciente, especialmente por ser figura estruturada ao redor de um furo. Se traçarmos um círculo sobre ele, o interior se comunica com o exterior. "Então, $\mathbf{A}=$ não $\mathbf{A}$ pode se escrever. Sendo o significante diferente de si mesmo, existe um espaço que não pode ser preenchido; e o mais simples dos significantes, fechando-se sobre ele mesmo, não pode senão se desdobrar entre si próprio e o outro que é, em relação a si mesmo". (DARMON, 1994, p. 128).

Com essa explicação topológica podemos entender um pouco mais a frase de Lacan "o significante representa um sujeito para outro significante". O sujeito emerge ai nesses intervalos, entre o $\mathrm{S} 1$ e o $\mathrm{S} 2$, ou, nesses espaços vazios não preenchidos ente o significante e ele mesmo. A técnica psicanalítica consiste, então, em operar, com os cortes das sessões, interrupções na cadeia significante, ou interpretações que apontem para a equivocação significante e façam deslocar o sentido. Acredita-se que só assim, aos poucos, com tempo e muita bavardage (falação) pode-se fazer transformações na estrutura de um indivíduo. O que isso poderia ensinar aos educadores? Lacan dá uma resposta para os analistas que nos interessou particularmente.

Prestem inclusive muita atenção para não terem a fraqueza de ir rápido demais pelo bem do singular, pelo bem daquele com quem lidam, porque sabem muito bem que não é querendo o bem das pessoas que se é bem sucedido e que, na maior parte do tempo, dá-se inclusive o contrário. Felizmente, contudo, para eles esta é uma idéia adquirida em virtude de sua experiência. (LACAN, 2006, p. 18). 
Interessa-nos examinar "não é querendo o bem, que se é bem sucedido". Vamos por partes, “cuidando para não irmos rápido demais". Estamos em um terreno nada consistente, já que o sujeito, "veiculado pelo significante em sua relação com outro significante, deve ser severamente distinguido tanto do indivíduo biológico quanto de qualquer evolução psicológica classificável como objeto de compreensão. Essa é, em termos minimais, a função que confiro à linguagem na teoria”. (LACAN, 1998, p. 890).

\begin{abstract}
Freud nos ensina que a motivação humana não é assim tão simples, dado o enorme papel do inconsciente na determinação das ações humanas, e Lacan nos ensina a buscar explicações na própria ordem simbólica: o inconsciente, diz ele, é o discurso do Outro, isto é, o inconsciente consiste em termos lingüísticos, frases, expressões, mandamentos, leis e convenções religiosas e sociais que fazem parte da cultura em geral, bem como de cada família. O inconsciente é composto pela fala dos pais e familiares de uma criança, fala que é em si amplamente determinada pelo mundo sociolingüístico a seu redor. Portanto, explicações, na opinião de Lacan, devem ser buscadas na ordem simbólica, na medida em que esta se tornou a base do inconsciente individual. (FINK, 1997, p. 76).
\end{abstract}

Constelação de insígnias que fazem parte da cultura em geral, bem como da família. Explicações que devem ser buscadas na ordem simbólica e na imagem que fazemos das pessoas com quem nos relacionamos, portanto, na ordem imaginária. Por isso, Lacan utiliza recursos da lingüística, matemática, topologia, algumas vezes até da física. Faz isso intencionalmente, para retirar a responsabilidade da constituição do sujeito, dos seres viventes, das pessoas, dizendo com a suas palavras: "para prevenir uma possível confusão com algum esquema de uma via de condução anatômica" (LACAN, 1998, p.680).

Para justificar que a psicanálise é uma prática discursiva e não personalista, como creditavam alguns psicanalistas, (ibid. p.678) Lacan recorre ao modelo ótico, a chamada "ilusão do buquê invertido", para dar conta da relação do eu com o outro, particularmente com o Ideal do $\mathrm{Eu}$, o que nos interessa particularmente no estudo de grupos. O que esse esquema representa? A imagem de um buquê é projetada na realidade, através de espelho esférico, e, é percebida pelo que olha, como se fosse real. O que Lacan extrai dessa experiência?

Primeiro, que a imagem que um bebê, de seis a dezoito meses, faz de si mesmo si, ao olhar e ser olhado no espelho, portanto, no inicio da formação do Eu, é uma ilusão. A antinomia entre as imagens, produtora do Eu ideal, confere o estatuto imaginário do sujeito. (ibid. p.683) Antinomia que resulta num transitivismo constante, dando suporte a incertezas, permitindo retificações, mas perpetuando o equivoco. Afinal, insistimos, com Lacan e Freud, 
a imagem na qual o sujeito muito reconheceu é uma ilusão, um Eu Ideal. Se pudéssemos escutar o pensamento do bebê ouviríamos: "aquele cara lá sou Eu: bonito, inteligente, fofo..." - como todos os filhotes são para as suas mães - e de repente, “mas alto lá! Quem é aquela ali me olhando? Outra mamãe? Qual a falsa?". Desculpe-nos exemplos tão pueris, mas estamos tratando de um vivente ainda prematuro quanto à percepção e ao desenvolvimento neurológico. Voltemos à teoria.

A essa imagem real, portanto se colam os significantes que vêm do Outro, o Ideal do $\mathrm{Eu}$, a pessoa que ocupa para nós o lugar de autoridade, é "nisso que se prende às coordenadas inconscientes do Eu. Continuando a escutar o nosso bebê, cada vez mais crescidinho, ouviríamos, "Há então é isso que ela pensa de mim, que sou bonito, inteligente, bom aluno, responsável...". Monta-se, então, a rede de significantes "não idênticos a si mesmo". A realidade está ai para nos mostrar, e ao nosso bebê, que entre o Eu Ideal, o Ideal do Eu e o Real há uma sucessão infinita de equívocos e distorções. É isso que Lacan quer nos lembrar com o seu retorno a Freud.

Resta ainda uma questão para nós, antes de voltarmos a falar do cartel, que como vimos no capítulo um, ocupou Freud em Psicologia das Massas e alguns estudiosos de grupos. Lá vimos na "topologia Freudiana, as três identificações e as três manifestações: inibição, sintoma e angústia. Vimos também na "topologia lacaniana" como um objeto qualquer pode ser colocado por muitos nesse lugar de Ideal, como ele pode "precipitar, com a sua insígnia, a identificação com o Eu Ideal”. Isso como evitar isso no cartel? Seria possível?

Lacan afirma (1975) que é claro que os seres humanos se identificam com o grupo. Nas palavras dele: "Quando não se identificam com o grupo, estão mal, devem ser trancafiados. Não estou dizendo ai, com que ponto do grupo, devem se identificar. O ponto de partida de todo laço social se constitui da não-relação sexual como furo”. (ibid.).

Apesar de haver impossibilidade do seu humano não se identificar no grupo, não há razão alguma de haver uma identificação satisfatória, já que não há possibilidade dele se não se identificar ao significante que falta no Outro. A explicação disso, para Lacan, se encontra na própria linguagem.

O significante mestre, o Nome-do-Pai, o Falo, os demais poderiam se identificar promete o que não pode cumprir, ao seja, a articulação a outro significante. O discurso também é impossível porque a identificação não faz desaparecer divisão do sujeito pela linguagem. Diante disso, Lacan inventou o objeto a, o significante que falta no Outro, aquele que também não se consegue atingir pela identificação e que se coloca no meio de todas as identificações entre as pessoas em um grupo. 
O nó borromeano, como escritura, dá suporte a essa estrutura da identificação, é uma maneira de operar o espaço habitado pelo sujeito, que já sabemos é o do inconsciente, constituído como uma linguagem, portanto dentro do discurso, leitura do mundo e das pessoas nos grupos.

\begin{abstract}
O nó borromeano estabelece a estrutura daquilo que Freud definiu como realidade psíquica, realidade determinada pela constrição que suspende uma condição desejante singular e indestrutível, demarcada por uma constelação de traços que estruturam a relação com o inconsciente. Diferentemente do que as coordenadas cartesianas propõem, a topologia do nó borromeu mostra outra maneira de operar o espaço habitado pelo sujeito, implicando uma geometria tridimensional, cujos pontos se determinam pela cunhagem de três círculos vazados, enganchados e inseparáveis, destacando a combinatória das relações que presidem a realidade psíquica. (VORCARO, opus cit. p.67)
\end{abstract}

Círculos vazados, enganchados, representando três dimensões, em que cada uma tem a função de sustentar as outras duas². e Basta que ao menos uma não se sustente para todo o enlaçamento ser desfeito. A menos que um quarto círculo seja adicionado: o sintoma, ou de outro modo, o nome próprio, o Nome-do-Pai, aproximações semânticas inadequadas, mas significantes que têm a propriedade de inserir o sujeito na linguagem, portanto na cultura. Nó, apresentado como uma imagem, mas efeito de linguagem.

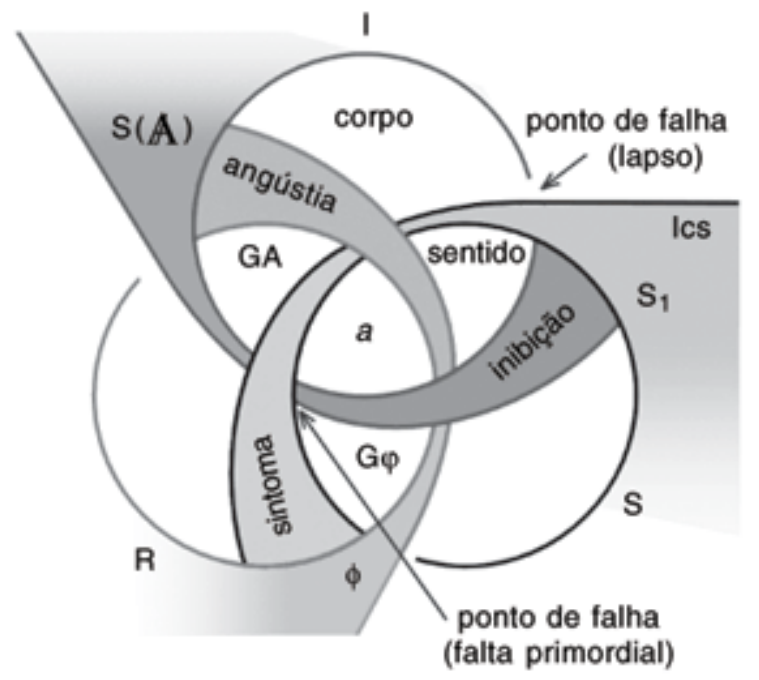

Fig. 1: (Darmon, opus. cit. p. 264)

Vimos que essa "metáfora" utilizada por Lacan para definir a sua criação grupal, o cartel. Ele parte das três identificações tratadas por Freud: a histérica, ao Pai e ao traço Unário; das três formações do inconsciente: inibição, sintoma e angústia. E cria a sua tríade: Imaginário, Simbólico e Real, que precisam estar enlaçados exatamente dessa forma, como mostra a figura acima.

\footnotetext{
${ }^{2}$ Não tratamos do real, nem do sintoma extensivamente nesta parte do trabalho, mas pretendemos fazê-lo.
} 
O imaginário, a consistência, representada pelo corpo, reproduzido por uma imagem de algo que falta. Quando ele invade o simbólico dá-se uma inibição que produz a anorexia mental, a inibição do saber. O simbólico, o possível, a linguagem, é um significante reenviando a outro um significante nuca cadeia sem fim, até que algo o barre. Quando o simbólico invade o real, temos o sintoma. Por fim o real, o impossível, se situa mais além da linguagem e é o campo aonde isso tudo se dá. Quando ele invade o imaginário, a imagem do corpo, podemos observar as palpitações, os tremores, etc.

Que leituras de grupo a psicanálise pode fazer a partir da sua topologia? Lacan na Proposição de 9 de outubro (1967/2003), fundamentado em Freud, descreveu três facticidades. Os grupos, por funcionarem no eixo especular, amor-ódio, são fortemente vinculadas pelo imaginário, são obscenos. Eles podem produzir segregação, o narcisismo das pequenas diferenças, é uma das facticidades do real, por que tem no horizonte a morte, metaforizada pelo campo de concentração. Também sem a referência ao Édipo, para Lacan melhor entendido como Nome-do-Pai, por ser um significante mestre, o grupo cai no delírio psicótico onde tudo no mundo ganha significação e perturba a sua existência.

Para dar mais consistência ao sistema e eliminar a propriedade borromeana que o deixa instável, Lacan precisou introduzir um terceiro círculo aos três já existentes, o sintoma. Essa rodinha a mais funciona como um operador, equivalente ao Nome-do-Pai, o sintoma. Ele que dá estabilidade a estrutura. É curioso que aquilo de que todos os neuróticos se queixam, seja exatamente o que dará estabilidade ao sistema. Parece que esse também é um ponto que a psicanálise pode contribuir aos que trabalham com os grupos. Mais do que eliminar o que não vai bem em um grupo e tentar amadurecê-lo, melhor aprender a lidar com ele. Para lidar com esses efeitos de grupo Lacan concebeu o cartel, um dispositivo para transmissão da psicanálise, que será apresentada no capítulo dois. Resta avaliar se ele foi bem sucedido.

Deixemos nesse ponto o nó borromeano, para tratarmos do dispositivo. Esse é um conceito da física que implica em linhas de forças trabalhado extensamente por Foucault ao longo de sua obra e que Gilles Deleuze, um dos seus interpretes, nos ajudou a compreender. (1990, p. 155-61). Vejamos do que se trata.

O dispositivo é como uma espécie de novelo ou meada, um conjunto multilinear, composto de linhas de natureza diferente que não abarcam, nem delimitam, sistemas homogêneos por sua própria conta, linhas que seguem direções diferentes e formam processos sempre em desequilíbrio. Essas linhas que tanto se aproximam como se afastam umas das outras. Não se contentam apenas em compor um dispositivo, mas atravessam-no, arrastam-no, de norte a sul, leste a oeste, na diagonal. São compostos de linhas de visibilidade (máquinas 
de fazer ver) de linhas de enunciação (máquinas de fazer falar), de linhas de força, linhas de subjetivação e linhas de ruptura que se entrecruzam, se misturam, suscitam variações e mutações de disposição.

A dimensão de visibilidade (máquinas de fazer ver) é composta de linhas de luz que formam figuras variáveis e inseparáveis em cada dispositivo. Cada dispositivo tem seu regime de luz, a maneira que esta cai, se esvai, se difunde ao distribuir o visível e o invisível, ao fazer nascer o objeto que não existe sem ela. A colocação em comum de imagens interiores e das angústias dos participantes, para as quais ele fornece uma imagem grupal, a qual podemos encontrar similares em diversos campos em que o homem se encontra em um grupo.

\footnotetext{
Uma reunião administrativa tropeça numa questão de ordem, se eterniza em um ponto secundário, se detém em picuinhas, cria dificuldades onde não existem, cede lugar a acertos de contas entre as pessoas, volta as costas a sua ordem de dia, e anda sem rumo, deleita-se com problemas que não são da sua alçada, evita suas responsabilidades, há destaque a boatos, suposições, intenções maquiavélicas atribuídas aos superiores, aos subordinados, aos trabalhos vizinhos, aos concorrentes, negligencia informações essenciais que possui, omite inteirar-se onde faltam informações, confia uma tarefa á aquele que é menos indicado para ter sucesso, critica e destrói tudo que lhe é proposto, e embarga qualquer conclusão que, ao saírem, os membros logo esquecerão. (ANZIEU, opus cit. p. 21-22)
}

Supostamente todos que trabalham em grupo, têm um interesse em comum, essa é a própria definição de grupo. Coordenadores querem que sua equipe de professores seja produtiva e competente, professores querem que seus alunos sejam colaboradores e obtenham resultados satisfatórios nos exames, psicanalistas querem ter uma formação de qualidade e fazer a transmissão da psicanálise acontecer e a práxis avançar. Todos enfrentam em seus grupos a mesma situação, isso supostamente predisporia que se mostrassem cooperantes, unidos, benevolentes, solidários. Mas não é isso que acontece, não há harmonia e pensamos que não só a dimensão de visibilidade, quanto a dimensão da fala e linhas de força que veremos a seguir podem contribuir para isso.

A dimensão da fala, as curvas de enunciações (máquinas de fazer falar), não são sujeitos nem objetos, são curvas nas quais se distribuem as posições diferenciais dos seus elementos, são enunciações que distribuem variáveis, regimes de enunciações que definem uma ciência, em um determinado momento, um gênero literário ou um movimento social, por exemplo. Regime que precisa ser definido em função do visível e do enunciável, com suas derivações, suas transformações, suas mutações. Podemos aproximá-las do simbólico.

As linhas de forças, que também compõem um dispositivo, de alguma maneira, "retificam" as curvas anteriores, traçam tangentes, envolvem os trajetos de uma linha com outra linha, operam idas e vindas entre o ver e o dizer, agindo como setas que não cessam de 
penetrar as palavras e as coisas, que não cessam de conduzir à batalha. Elas são invisíveis e indizíveis, estreitamente mescladas com as outras linhas, mas, entretanto, é indistinguível destas. Trata-se da "dimensão do poder", a terceira dimensão do espaço interno do dispositivo, variável em cada um deles. Esta dimensão se compõe tanto com o poder como com o saber. Podemos aproximá-lo do real, silencioso, mas poderoso.

Montado seu esquema de dispositivo, Foucault percebia que algo não estava correto nos seus mapas, com três linhas apenas. Sentia que não podia deixá-los fechar-se em linhas de forças intransponíveis, de contorno definitivo. Pensava que tinha que ser possível transpor a linha de força que fechava o dispositivo, chegar ao outro lado. Para isso verificou que isso pode acontecer quando a linha de força se volta sobre se mesma, afeta-se a si mesma. Para dar conta disso, definiu as linhas de subjetivação, descobertas em um período posterior.

O si-mesmo não é nem um poder, nem um saber, não é uma determinação préexistente e já acabada. Ele é um processo, uma produção de subjetividade em um dispositivo, ela está para si fazer, na medida que o dispositivo o deixe ou o faça possível. É uma linha de fuga que escapa as linhas anteriores. É um processo de individuação que diz respeito a grupos ou pessoas, que escapa tanto às forças estabelecidas como aos saberes constituídos: uma espécie de mais-valia. São regras facultativas do domínio de si-mesmo que constituem uma subjetivação, autônoma, verificáveis no modo grego de funcionar, nas sociedades modernas, por exemplo. Elas implicam em movimento, em instabilidade ${ }^{3}$.

Essas linhas de subjetivação são um extremo limite de um dispositivo, elas esboçam a passagem de um dispositivo ao outro, nesse sentido elas predispõem as linhas de fratura, ruptura ou fissura. Deleuze exemplifica dizendo que os que se subjetivam são tanto os nobres, "os bons", quanto os excluídos, "os maus", os pecadores, os eremitas ou os heréticos: toda uma tipologia das formações subjetivas, em dispositivos móveis. E, por todos os lados, há emaranhados que é preciso desmesclar: produções de subjetividade que escapam dos poderes e dos saberes de um dispositivo para colocar-se sob os saberes e os poderes de outro, em outras formas ainda por nascer. Essa é a característica das linhas de ruptura, uma forma possível de lidar com os grupos.

Deleuze aponta, ainda neste artigo, duas conseqüências importantes para uma filosofia dos dispositivos. A primeira é o repúdio dos universais. "Com efeito, o universal nada explica, é ele que deve ser explicado" (opus cit). Todas as linhas são de variação, que não tem

\footnotetext{
${ }^{3}$ Mas não é certo que todo dispositivo disponha de um processo semelhante. Verificamos essa impossibilidade em alguns grupos secundários, com forças rigidamente estabelecidas e saberes fortemente constituídos, que não favorecem a mudança, a autoria.
} 
sequer coordenadas constantes. O Uno, o Todo, o Verdadeiro, o objeto, o sujeito não são universais, mas processos singulares de unificação, de totalização, de verificação, de objetivação, subjetivação, processos imanentes em um dado dispositivo. E cada dispositivo é uma multiplicidade na qual esses processos operam em devir, distintos do que operam em outros dispositivos.

A segunda consequiência possível de se extrair de uma filosofia dos dispositivos é uma mudança de orientação que se separa do eterno para apreender o novo, variável em cada dispositivo. Foucault recusa explicitamente a originalidade de uma enunciação. Argumenta dizendo que a contradição de duas enunciações não basta para distingui-las, nem para marcar novidade de uma em relação à outra, porque o que conta é a novidade no próprio regime de enunciação que pode compreender enunciações contraditórias - "é a novidade no regime que conta, a novidade do dispositivo da Revolução Francesa ou Bolchevique e não a originalidade da enunciação". (opus cit). Todo dispositivo se define pelo que detêm em novidade e criatividade, o qual marca, ao mesmo tempo, sua capacidade de se transformar ou se fissurar em proveito de um dispositivo futuro.

Pertencemos a certos dispositivos e neles agimos. A novidade em um dispositivo em relação aos anteriores é o que chamamos a sua atualidade, nossa atualidade. O novo é o atual. O atual não é o que somos, mas aquilo em que vamos nos tornando, o que chegamos a ser, quer dizer, o outro, nossa diferente evolução. Em outras palavras, a história é o arquivo, o que somos e deixamos de ser, enquanto que o atual é o esboço daquilo que vamos nos tornando. Dizendo ainda de outro modo, história nos separa de nós próprios e o atual é esse outro com o qual já coincidimos.

Freud é um exemplo desta transformação e possibilidade de criação dentro do nosso tema de pesquisa. Enriquez e Costa (1998) traçam esse panorama para nós. A tese central é de que a sexualidade tem um tal poder de coerção sobre a vida humana que só uma força de igual porte, a ameaça de morte ou a culpabilidade pelo assassinato, pode contê-la. Em Totem e Tabu o instrumento de controle era a promessa de morte; na Psicologia das Massas, a promessa de amor: "sabemos que o amor impõe um freio ao narcisismo, e seria possível demonstrar como, agindo desta maneira, ele se tornou um fator de civilização" (p.157) ou ainda, que só uma instituição que disponha o poder de morte sobre os indivíduos pode conter essa força disruptiva, que busca satisfação absoluta a qualquer preço, uma força que possa barrar os excessos narcísicos.

Somos de opinião, pois, que a linguagem efetuou uma unificação inteiramente justificável ao criar a palavra 'amor' com seus numerosos usos, e que não podemos fazer nada melhor senão tomá-la também como base de nossas discussões e 
exposições científicas. Por chegar a essa decisão, a psicanálise desencadeou uma tormenta de indignação, como se fosse culpada de um ato de ultrajante inovação. Contudo, não fez nada de original em tomar esse amor em sentido 'mais amplo'. Em sua origem, função e relação com o amor sexual, o 'Eros' do filósofo Platão coincide exatamente com a força amorosa, a libido da psicanálise, tal como foi pormenorizadamente demonstrado por Nachmansohn (1915) e Pfister (1921), e, quando o apóstolo Paulo, em sua famosa Epístola aos Coríntios, louva o amor sobre tudo o mais, certamente o entende no mesmo sentido 'mais amplo'. (ibid. p.116)

O líder, a quem as pessoas devem temer ou amar, é desde sempre e para sempre um elemento que não pertence a classe lógica dos elementos. Ele fica a parte do todo, ocupando o lugar Ideal, de onde emana a ordem para o Ego recalcar essa ou aquela representação pulsional. Em Futuro de uma ilusão, (p. 22) Freud afirma que a tarefa principal da civilização, sua razão de ser é proteger contra a natureza, porém a cultura, para que os homens possam abrir mão da sua liberdade, deve oferecer em troca um consolo narcísico: o direito de desprezar os que não pertencem a sua cultura, já que os que oprimem, mesmo de uma classe inferior, se vêm identificados com a classe que governa, com os senhores; a religião, que reconcilia os homens com a crueldade do destino e a arte, que lembra aos indivíduos seus idéias mais elevados. (p.20-25). São os narcisismos das pequenas diferenças.

Será que podemos atribuir ao narcisismo a grande dificuldade de se trabalhar em grupo? Vimos que a importância do estudo dos grupos reside no imaginário, introduzimos com Lacan a importância de uma análise no eixo simbólico, portanto da linguagem como possível de oferecer resistências, mas também criar algo novo. Três psicanalistas contemporâneos que viveram esse período entre guerras, tentaram realizar algo novo no campo da psicanálise em relação ao grupo. Resta-nos dialogar com eles a partir desse olhar discursivo para os grupos, mas procurando ver o que eles podem nos ensinar do trabalho que desenvolverem nos seus países e que se transmitiu para o resto do mundo. Vejamos como isso vai ser transmitido para nós. 
ALGUMAS PROPOSTAS DE FUNCIONAMENTO EM GRUPO 


\section{CAPÍTULO 2. Algumas propostas de funcionamento em grupo.}

Como verificamos no primeiro capítulo existem poucos estudos de psicanálise que tratem do estudo dos grupos no campo educacional, que tomem a análise do professor como integrante do grupo classe. Em contrapartida, existem muitos estudos de grupos no campo da psicanálise saturados de grupalidade, ou seja, transposições do funcionamento do aparelho psíquico individual para o funcionamento dos grupos, visto como "ser", que "pensa" e "sente". Levantamos algumas considerações sobre os possíveis motivos da resistência ao estudo dos grupos e apresentamos, de forma geral, a dimensão imaginária e simbólica dos grupos, priorizando o estudo das metáforas utilizadas para defini-los.

Até o momento trabalhamos com o tema de forma geral. Recolhemos alguns elementos importantes para dar conta do nosso problema de pesquisa. Agora, necessitamos diminuir o foco. Escolhemos realizar nesse movimento um estudo de três propostas de trabalho em grupo, feitas por psicanalistas contemporâneos, Pichon, Bion e Lacan. Dois pontos foram importantes para a nossa escolha: todos são freudianos na origem e fizeram uma abordagem pontual e criativa dos grupos, ao nosso entender, sem transpor o funcionamento do aparelho psíquico para os grupos, o que é uma característica das teorias de grupos saturadas de grupalidade.

Os autores privilegiados neste capítulo, encontram-se dentro de um determinado contexto histórico, todos são contemporâneos e psicanalistas; os dois primeiros com formação kleiniana e o último declaradamente freudiano. Apesar de todos três terem vivido num período entre duas grandes guerras e terem produzido teoria na metade do século $\mathrm{XX}$, reconhecemos que cada autor tem um vasto campo de referência conceitual e práticas bastante diferenciadas. Estamos advertidos de que não poderemos abordar a totalidade de cada uma das práticas e os seus esquemas referenciais, mesmo porque não acreditamos que isso seja possível, mas pretendemos minimamente, nessa parte do trabalho, verificar em que pontos podem eles se aproximar e em que pontos não há essa possibilidade.

Os grupos em pauta nesse capítulo são: o grupo operativo, desenvolvido por Pichon; os grupos de suposição básica e de trabalho, delimitados por Bion e o cartel criado por Lacan. Destacaremos de cada um deles os principais pressupostos e modos de funcionamento, não para avaliar se são bons ou maus, mas para retirar de cada uma das propostas feitas pelos autores algo que possa nos ensinar sobre a transmissão nos grupos: ponto de intercessão entre o campo educacional e psicanalítico. 


\title{
2.1.1. Grupo Operativo: uma invenção para operar mudanças.
}

\begin{abstract}
O investigador no campo científico deve estar capacitado para não ser vítima da sua ideologia ou de seus pensamentos prévios, para poder corrigir o seu esquema referencial. (...) ele deve observar a experiência real e concreta, confrontá-la com seu esquema referencial para saber de que classe de fenômeno se trata e, finalmente retificar seu esquema prévio, mas com a idéia de enriquecê-lo e não porque esse esquema é bom ou mau. (PICHON, 1987, p. 8).
\end{abstract}

Pichon diferenciava os grupos em três tipos: de ensino, onde há ampla comunicação intelectual e afetiva entre docentes e alunos; grupos de psicoterapia, com estrito senso terapêutico e o grupo de aprendizagem, nos quais os fatores de aprendizagem se conjugam com a psicoterapia. Este grupo difere dos anteriores pela existência de um tema de estudo e, desse ponto de partida, alcançam-se fatores emocionais que intervêm na dinâmica grupal. Esse grupo é denominado de grupo operativo e é a proposta de trabalho que será tomada, por nós, para análise.

Ele foi concebido e desenvolvido por Pichon-Rivière (1907-1977), que teve contato e sofreu a influência de diferentes grupos culturais ${ }^{4}$. Acredita-se que a constante busca de Pichon pela articulação de diferentes pontos de vista de um mesmo fenômeno e a visão integradora e totalizadora da sua teoria, deve-se a essa sua origem.

Para esse autor a estrutura é o vínculo instrumental, situacional e avaliado no aqui e agora. O sujeito é social, analisado no cotidiano, na relação que estabelece com as pessoas, nos papéis que ocupa nos grupos. Esses papéis são baseados em modelos internos, construídos ao longo da vida do sujeito, ancorados na situação triangular familiar, que evolui para uma rede multidirecional.

\footnotetext{
$\mathrm{Na}$ vida de relação sempre assumimos papéis e adjudicamos papéis aos outros. Todas as relações interpessoais em grupos social, em uma família, etc, são regidas por um permanente interjogo de papéis assumidos e adjudicados. Isto é, precisamente, o que cria a coerência entre o grupo e os vínculos dentro de tal grupo. (PICHON 1987, p, 128)
}

Essa forma segundo a qual Pichon vê o sujeito, parece-nos estar claramente relacionada ao conceito de indivíduo, persona, aquele que tem status civil, anda pelo mundo, assume papéis e se relaciona com outras pessoas. Na nossa linguagem, diríamos que esse

\footnotetext{
${ }^{4}$ Apesar de ter vivido grande parte da sua vida na capital da Argentina, e de ter convivido com escritores e intelectuais de vanguarda, foi criado, dos 03 aos 16 anos, em uma comunidade agrícola onde os habitantes eram, na sua maior parte, nativos guaranis e negros africanos. Como seus pais eram de origem européia, a cultura e língua francesa lhe foram passadas muito cedo e, antes mesmo de aprender o espanhol, aprendeu o Guarani.
} 
autor faz uma abordagem da questão no eixo imaginário. Um ponto de vista sobre um fenômeno que respeitamos, afinal não queremos ter velhas opiniões formadas sobre tudo. Ele, tal como outros autores estudados, ancora a base da estrutura tríplice, que podemos aproximála do nó borromeano, mas que evolui para uma rede multidirecional.

Esse nos pareceu ponto interessante de ruptura do sistema trino, tal como a função das linhas de fissura apresentadas por Foucault. Parece-nos, que sem dizer, Pichon se aproximava do que havia de mais simbólico na linguagem, constituída como rede. Uma rede de tensões constantes que operam na constituição do sujeito do inconsciente. Um bebê, puro real; um imaginário, uma mãe; e um simbólico entre os dois, operando com ritmo, oscilando entre tensão e apaziguamento. ${ }^{5}$

Pichon explica com os significantes da sua rede discursiva que a doença mental acontece quando essa estrutura universal familiar se torna fonte de tensões para o sujeito, tornando-o porta-voz da ansiedade e da angústia do grupo, cheio de estereotipias e imobilizando na assunção de novos papéis, que não o do doente mental. De outro modo, a família, a depositante da ansiedade e da angústia, o depositado, e o paciente, o depositário, criam a "tríade de letras d" e representam essa estrutura universal familiar, fonte de tensões para o sujeito.

O "aluno-problema" pode ser considerado o porta-voz da dinâmica grupal (Silva C. 2002), isto é, “aquele que, por meio de condutas ou verbalizações que, na maioria dos estabelecimentos de ensino, são consideradas inadequadas, denuncia as insatisfações, discordâncias e frustrações, assim como outros sentimentos, que estejam presentes no grupoclasse ou no contexto escolar mais amplo". (ibid. p. 70).

Essa forma de pensar a doença mental, ou o "aluno-problema”, não representa para Pichon uma concepção meramente exógena sobre a etiologia da questão. Ele entende a doença como uma disposição do sujeito, um núcleo depressivo e melancólico, que é o aspecto endógeno, para desenvolver determinado quadro patológico e como "destino do sujeito", o aspecto exógeno, adotando assim uma compreensão dialética da realidade e da etiologia das disfunções.

A compreensão dialética nos coloca o fato que não existe nenhuma contradição
entre uma situação fechada e uma situação aberta, uma vez que se trata de situações
transitoriamente ou sucessivamente fechadas ou abertas, criando uma situação em
espiral. Todas as perturbações no desenvolvimento, sejam as neuroses ou psicoses,
se produzem precisamente por um estancamento do processo fechado (...) que dizer
um pattern de conduta pode se repetir frente a estímulos variados. (...) Em termos de
aprendizado podemos dizer que o processo terapêutico consiste basicamente em

\footnotetext{
${ }^{5}$ Ver com mais detalhes essa operação de constituição do sujeito a partir do enlaçamento do RSI em Vorcaro (2004).
} 
abrir o círculo vicioso e provocar a abertura para o mundo exterior. (PICHON, ibid. p. 95).

Destacamos nesse autor também a afinidade com o princípio de não contradição, que vimos, que organiza a linguagem do inconsciente. O problema para a linguagem é quando há um estancamento, ela deixa de procurar sentido, "o que isso quer dizer" e deslocar e passa a um processo fechado onde tudo passa a fazer sentido, como no caso das psicoses. Tomemos o exemplo de alguém falando na televisão sobre um determinado plano político. Aquele que padece de uma doença mental diria que "certamente", "sem dúvida alguma", tratar-se-ia de um plano de conspiração contra ele.

A metodologia de trabalho proposta por Pichon de abrir o círculo vicioso e estereotipado consiste em operar mudanças e transformações nessas condutas estereotipadas, nas redes de comunicação, que para Pichon se dá sempre em três: quem fala, para quem se fala e de quem se fala, sendo que o ruído é invariavelmente o terceiro. A proposta de trabalho, que pode ser de aprendizagem, cura ou diagnóstico é que, através da empatia e da alteridade entre os integrantes de um grupo operativo, reunidos em torno de uma tarefa, mudanças possam ser operadas. ${ }^{6}$ Nessa dialética o papel da autoridade, do coordenador do grupo, é bem ativo.

Ele reflete com os integrantes de um grupo sobre as relações que estabelecem entre si e a tarefa e as dificuldades de levá-las a cabo. Ele ajuda o grupo a pensar, abordando os obstáculos epistemológicos configuradas pelas ansiedades básicas e tenta manter e fomentar uma boa comunicação. Os operadores utilizados pelo coordenador são a assimilação das situações manifestas e a interpretação da causalidade. A avaliação do grupo é feita partindo das diferentes formas de integração grupal.

Será que poderia haver "boa" comunicação? Partindo da teoria de conjuntos explicitada no primeiro capítulo, vimos que todo conjunto implica em seu contrário. Para haver o conjunto da "boa" comunicação, precisaria haver o seu complementar composto da "má" comunicação. Seria possível separar de um lado a boa e de outro a má? "Seria o simbólico separável?" Para tentar responder cabe analisar o que é uma separação de espaço. ${ }^{7}$

\footnotetext{
6 “Quando menciona aprendizagem, Pichon refere-se a toda sorte de aquisições, incluindo desde a aprendizagem de hábitos de comportamento iniciados com o nascimento, até a aprendizagem necessária à adaptação à vida, incluindo, portanto, a aprendizagem escolar". (SILVA C. opus cit. p. 72).

7 “Topologicamente, uma separação de um espaço x é um par A, B de subconjuntos não-vazios de x, tais que a reunião de $\mathrm{A}$ e de $\mathrm{B}$ constitua $\mathrm{x}(\mathrm{A} U \mathrm{~B}=\mathrm{x})$ e tais que sua intersecção seja vazia $(\mathrm{A} \cap \mathrm{B}=\emptyset$ ). Um espaço que não possua separação é dito conexo. Por exemplo, um conjunto finito de pontos, ou um espaço constituído pela reunião do interior e do exterior de um círculo num plano, são espaços separados: um disco, um segmento de reta, são espaços conexos". (ibid.).
} 
O simbólico, apesar de parecer separável, tem uma estrutura conexa, ou seja, colada. “A língua não admite nenhuma separação natural". Darmon, a quem recorremos em nosso auxilio, cita o exemplo que mesmo dividindo o dicionário em dois, existiriam palavras que pertenceriam aos dois lados; que mesmo línguas distintas, possuem nomes próprios intraduzíveis. "Na língua nenhum significante é isolável, mesmo em seus constituintes mais microscópicos, a língua é formada de termos complexos, de diferenças”. (1994, p. 146). Não estaríamos falando da ambigüidade presente no mesmo objeto e na língua?

Quando um espaço conexo é dividido em dois, um espaço é aberto e o outro é fechado. Em nível do corte, a fronteira adere a uma das duas partes. Assim, o corte de um segmento de números reais, em nível de um ponto $\mathrm{C}$, implica que esse número $\mathrm{C}$ pertença a um dos segmentos resultantes, e não ao outro. Isso se deve a estrutura conexa do segmento. (ibid.).

$\mathrm{C}$

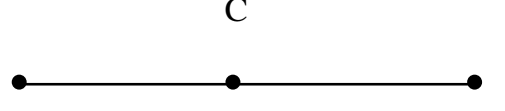

$\mathrm{C}$

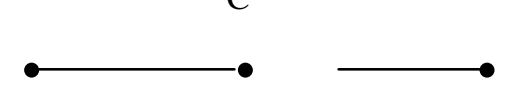

O outro segmento conterá uma extremidade 'aberta', e nessa extremidade, uma série infinita de números convergirá em direção a $\mathrm{C}$ sem jamais atingi-lo. (ibid).

Assim, o simbólico é conexo. Se não o fosse, seria possível uma divisão natural, e conseqüentemente um rapport sexual entre uma parte masculina e outra feminina exatamente equivalentes. Também se não o fosse, seria possível pôr de um lado a boa comunicação e do outro a má comunicação. Dizendo de outro modo, a divisão dos fala-seres não é nada simétrica, implica em um fechamento por um lado e uma abertura pelo outro. É essa divisão, essa a falta de rapport sexual que a castração vem atenuar.

A castração, ou a separação, divide o simbólico em um espaço aberto, de um lado, com cada significante reenviando a um outro significante, de onde extrai-se a frase "a verdade não pode ser dita toda"; e um espaço fechado, de outro, estabilizado pelo significante fálico, ou o Nome-do-Pai. Um significante mestre que vem colocar um lastro, dar um sentido ao simbólico estabilizando-o, nos ensina Lacan, nas palavras de Darmon.

Como entender, com essa análise da linguagem, as dificuldades de levar uma tarefa a cabo? Como entender a ansiedade nos grupos diante de uma nova atividade ou novos integrantes? Pichon diz que uma das causas que dificultam a realização da tarefa é a ansiedade gerada pela necessidade de mudança no padrão de funcionamento, relacional ou cognitivo intrínseco à realização de qualquer atividade nova. Ele defende que ao deparar-se 
com a necessidade de uma mudança o indivíduo adota uma atitude favorável ou oferece uma resistência inconsciente.

Estaria a dificuldade de realizar uma tarefa nessa estrutura de linguagem que não faz laço comum entre significante e significado, nem entre o significante e as coisas? Vimos no capítulo um que cada um dos integrantes de um grupo organiza sua própria rede de linhas preferenciais entre os significantes. Estes significantes são organizados segundo uma "rede de puras diferenças"; se esta não é nada harmônica na individualidade, como poderia ser na coletividade? A questão que nos concerne é como fazer par o que não faz par? Como fazer os grupos, nas escolas e instituições, realizarem as tarefas que se propõem?

Para Pichon, a resposta estava em consonância com a teoria que lhe referenciava modos diferentes de ver a mesma realidade - que respeitamos. Para ele a resistência à mudança pode ser por medo da perda do conhecido, do estabelecido, - ainda que se trate de uma posição incômoda como é a do aluno-problema - ou por medo do ataque, do risco de lidar com o desconhecido e não ser capaz de enfrentar uma nova situação. Ou seja, o medo da perda suscita uma "ansiedade depressiva" e o de ataque "uma ansiedade paranóide" conceitos retirados da teoria kleiniana e o exemplo que Pichon nos fornece nessa passagem é da loucura como "distorção da comunicação".

\footnotetext{
O paciente teme que não seja aceito em uma situação de comunicação direta, ou que se rompa a comunicação, ou atacar ou destruir o objeto e, em consequiência, perdê-lo e interromper a relação com ele. (...) pode, então, iniciar teoricamente um longo relato, ou um longo monólogo, ou um diálogo incoerente, com a finalidade aparente de tomar distância. (...) uma defesa contra a ansiedade que pode ficar crônica. (...) O distanciamento é, então, uma conduta defensiva, seja para evitar a frustração de perder a comunicação, seja pelo perigo de destruir o objeto e ficar desamparado, ou pelo temor de ser pego pelo objeto em uma situação paranóide e ser por ele destruído". (opus cit. p. 132-3).
}

Essa teoria da comunicação é utilizada por ele e outros autores como referência para entendimento do papel do "aluno-problema", aquele que é o "porta-voz" dessas ansiedades, já que "denuncia" o conteúdo que está latente no grupo e em si próprio, seu "mistério familiar", que mobiliza fantasias de culpabilidade. O aluno neste papel, segundo Silva, C. (ibid. p.74), revela insatisfações e inadequações presentes no grupo-classe, "sentimentos estes suscitados pela realização da tarefa de aprender, e que os demais participantes não estejam conseguindo perceber ou não estejam encorajados a ponto de evidenciar".

Ao longo do seu trabalho ela levanta a hipótese que essa talvez seja uma das razões que mobiliza os professores a adotar estratégias de intenso controle deste aluno; atribui ao aluno "indisciplinado" ou "problemático" uma causalidade familiar; exime-se da responsabilidade de fazer uma leitura crítica do seu ensino ou do componente curricular e da 
promoção de condições para que o próprio grupo-classe se identifique na fala do "porta-voz" e busque soluções para as dificuldades encontradas.

Silva defende a necessidade, e nós estamos de acordo, de um conhecimento do funcionamento dos grupos daqueles que atuam na educação, não para fins terapêuticos, mas como mais um instrumento facilitador da aprendizagem. Pichon tinha essa intenção quando escreveu as "Leis básicas da técnica do grupo operativo" aplicáveis em qualquer setor de tarefa ou investigação (ibid. p.123).

Seu instrumento único é o ECRO (esquema conceitual, referencial e operativo), conjunto estrutural e genético, que permite a compreensão horizontal (a totalidade comunitária) e vertical (o indivíduo nela inserido). Para ser um grupo operativo, ou seja, para se obter mais produtividade, há necessidade de se trabalhar com maior heterogeneidade possível de membros, com maior homogeneidade na tarefa. Para que o coordenador de um grupo operativo possa encarar uma tarefa corretora, ele precisará manejar um ECRO encarnado em alguns papéis funcionais e rotativos: porta-voz, bode expiatório, líder e sabotador e passos operacionais: relacionados aos momentos temporais da sessão do grupo e da tarefa.

Vimos anteriormente o conceito de porta-voz. Acrescentaríamos que é aquele que fala por todos e conjuga na verticalidade, sua história pessoal e na horizontalidade a comunidade em que está inserido. Geralmente é um membro forte, já que suporta toda a ansiedade do grupo familiar ou comunitário nele depositada. O bode expiatório é um membro depositário dos aspectos negativos do grupo, através dele aparece a segregação. ${ }^{8}$ Em oposição, o líder é aquele membro depositário dos aspectos positivos do grupo, sentimentos de pertença, de cooperação, etc. O papel de sabotador, papel complementar, representado por uma liderança resistente a mudança, que invade uma situação de competição que paralisa a tarefa. (ibid. p. 128).

O passo operacional do coordenador, como vimos anteriormente, é ajudar os membros do grupo a pensar, utilizando técnicas que "consistem em criar, manter e fomentar a comunicação que vai adquirir desenvolvimento progressivo em forma de aspiral”. (ibid. p. 36). Através do uso da escala de avaliação básica, baseada em modelos de conduta grupal, ponto de referência para a construção das interpretações do coordenador, o grupo aprende, se

\footnotetext{
8 Também se houver aumento do desamparo, da insegurança e incerteza o grupo pode se estruturar como conspirador, situação constante e latente em todo grupo social, que muitas vezes coloca o coordenador, agente de mudança, como "bode expiatório".
} 
comunica, opera, alivia-se da ansiedade básica. Com isso reduz-se o nível de ambigüidade, do mal entendido, favorece os vínculos dentro do grupo e favorece as rupturas dos estereótipos.

$\mathrm{O}$ primeiro vetor da escala de avaliação básica são os fenômenos de afiliação ou identificação (ibid p. 125). Em um primeiro momento, o indivíduo guarda certa distância sem se incluir no grupo (afiliação) e num segundo momento, de maior integração ao grupo (pertença), os membros se permitem elaborar uma estratégia, uma tática, uma técnica e uma logística, que tornam possível o planejamento.

Um outro vetor existente no trabalho de grupo é o da cooperação estabelecida sobre a base de papéis diferenciados. Ainda que exista uma contribuição silenciosa, através da cooperação que se torna manifesto o caráter interdisciplinar do grupo operativo e o interjogo da horizontalidade e da verticalidade.

O terceiro vetor, chamado pertinência, consiste no centrar-se do grupo na tarefa prescrita e no estabelecimento da mesma. Avalia-se a qualidade dessa pertinência de acordo com o montante da pré-tarefa, da criatividade e da produtividade do grupo e suas aberturas para o projeto.

O vetor seguinte analisado por Pichon é o da comunicação, que pode ser verbal ou pré-verbal. Quando dois elementos entram em contradição, configura-se o mal-entendido.

A aprendizagem, outro vetor e fenômeno básico de todo grupo operatório, é obtida pela somatória da informação dos integrantes dos grupos. Ela produz uma mudança qualitativa no grupo, que se traduz em termos de resolução de ansiedades, adaptação ativa à realidade, criatividade e projetos.

A tele, disposição positiva ou negativa para trabalhar com um membro do grupo, uma transferência positiva ou negativa do grupo com o coordenador ou com os membros entre si configurada no "clima" do grupo.

O último e central vetor é o estereótipo, uma atitude ante uma mudança que se modifica em termos de incremento ou resolução de ansiedades depressiva ou paranóide, coexistentes e co-operantes em tempo e espaço. Todos estes vetores estão configurados em três grandes momentos: a pré-tarefa, a tarefa e o projeto.

Durante a pré-tarefa técnicas defensivas da posição esquizoparanóides de cisão, dissociação entre o sentir, o pensar e o agir, se põem em jogo. Elas são mobilizadas pela resistência à mudança e são destinadas a postergar a elaboração das ansiedades que funcionam como obstáculo epistemológico. Tudo é feito "como se" estivesse executando o trabalho 
solicitado, atividades para passar o tempo, formas de não entrar na tarefa que podem causar frustração, levar ao estereótipo e a não produção do grupo.

A tarefa, por sua vez, é quando o objeto do conhecimento se torna penetrável através de uma elaboração da posição depressiva, que torna consciente o inconsciente favorecendo que o individuo tenha uma "percepção global" dos elementos em jogo, com a possibilidade de manipulá-los, o que implica na ruptura da pauta estereotipada, que funciona como estancamento da aprendizagem e deteriorização da comunicação. Assim, a tarefa implica numa mudança em dupla direção, a partir do sujeito e para o sujeito, envolvendo a constituição do vínculo.

O sujeito apareceria com uma percepção global dos elementos em jogo, com a possibilidade de manipulá-los e com um contato com a realidade no qual lhe é acessível o ajuste perceptivo, ou seja, o situar-se como sujeito e por outro lado, lhe é possível elaborar estratégia e táticas mediante as quais pode intervir nas situações (projeto de vida), provocando transformações que modificarão a situação que se tornará nova para o sujeito e o processo começará novamente como uma espiral (ibid. p.21).

Nessa passagem da pré-tarefa para a tarefa, as pessoas podem assumir novos papéis e responsabilidade, abandonando progressivamente os velhos papéis, inadequados para o aqui e agora, aumentado o sentimento de pertença e cooperação que dão ao grupo grande produtividade (ibid. p.114), fazendo-os concretizar o projeto, último momento do grupo operativo, quando se consegue a pertença dos membros e concretiza-se uma planificação, uma ação.

O grupo se propõe objetivos que vão mais além do aqui e agora, construindo uma estratégia para alcançar o objetivo. Mas, dentro desse aqui e agora, podemos interpretar esse projeto, como todo mecanismo de criação, está destinado a superar a situação de morte ou de perda que os membros vivenciam quando, através da realização da tarefa, percebem a possibilidade da separação ou finalização do grupo". (ibid. p. 130).

Para Silva C., o professor é o responsável por essa transformação nos alunos, ele deve minimizar as ansiedades paralisadoras do processo de mudança, mas mantê-las em um nível suportável e necessário para favorecer a mudança, num processo continuo de construção e desconstrução. Bleger, referindo-se ao trabalho de grupos operativos no ensino, aponta para a necessidade deste processo de desconstruções e construções na aprendizagem.

Sem ansiedade não se aprende, e com muita ansiedade também não. O nível ótimo é aquele no qual a ansiedade funciona como sinal de alarme. Existem duas condutas grupais extremas e típicas; uma é aquela na qual não existe ansiedade e o grupo não trabalha; já "sabem tudo" e não existem dúvidas, de modo que fica bloqueado o aparecimento de qualquer novo emergente. No primeiro caso, deve-se questionar a ansiedade em função do tema; (...). No segundo caso, deve-se questionar o bloqueio, também em função do impacto do tema. Em ambos há um obstáculo epistemológico 
agindo: através de uma ruptura muito brusca de esquema referencial num caso, e da estereotipia no outro. (ibid. p. 52).

Esse é o interjogo dialético com o mundo analisado por Pichon. Através de uma rede de comunicação constantemente reajustada, o sujeito apreende o objeto, adapta-se à realidade, transforma-a. Transformando-a, modifica-se a si mesmo, re-elabora um pensamento capaz do diálogo, transforma o ECRO, enfrenta a mudança, realiza nova aprendizagem e reinicia o processo dialético, uma espiral aberta, uma adaptação ativa à realidade, muito diferente do círculo fechado, da pauta estereotipada de conduta. O professor na sua prática deveria favorecer a transformação do "aluno-problema", romper as suas condutas estereotipadas, evitar atitudes segregacionistas e adjudicar-lhe um novo papel, o de "agente de mudança social”. (PICHON, 1999, p. 38)

Orientados pela psicanálise, que toma a linguagem por referente, diríamos que: existe um significante primordial que falta para todos, homens e mulheres, professores e alunos. Há um recalque primordial que não pode passar pelo dizer e o simbólico está aberto para todos os seres-falantes. O que faz o sujeito diante desta falta? Tenta obturá-la imaginariamente com objetos, amigos, amores, líderes. Todos que ocupam esses lugares ganham forte investimento narcísico. Assim as pessoas se juntam nos bandos, nas gangues, nos grupos de suposição básica, achando que encontrarão o objeto que suturará essa falta, que como vimos é da ordem da linguagem.

Nesse interjogo dialético com o mundo o sujeito do inconsciente, sujeito dividido, efeito do deslizamento significante, gira ao redor deste impronunciável, do buraco do recalcamento primordial. Qualquer objeto que se coloque para capturar essa falta será inadequado. Dentro desta lógica, o professor, psicanaliticamente advertido, não deve querer suturar essa falta no aluno, porque ela é estrutural e está presente em todos. Seu compromisso é consigo mesmo e com o seu desejo de saber. Alguém que não como o analista, mas como um analisando, que supõe que é o outro que sabe ${ }^{9}$. Só deste lugar, possa ampliar a sua rede discursiva, produzir significantes novos que podem através da linguagem operar mudanças.

Pichon com seu forte desejo de operar mudanças foi atraindo outros para seu lado. Ele constituiu um sólido campo de atuação na psicologia, a psicologia social, pois na sua concepção, toda psicologia é social. Assim, ele criou a sua escola de formação de psicólogos sociais, centrada na técnica operativa de ação grupal, como forma de transmissão de

\footnotetext{
${ }^{9}$ Ver mais sobre o professor na posição de analisando em Kupfer. (1990, p.191).
} 
conhecimentos e na aprendizagem de tarefas corretoras. Através desta técnica pretendeu fazer leituras críticas da realidade, no seu campo de trabalho que é o grupo, onde acontece "o implacável interjogo entre o homem e o mundo", o palco das transformações.

[...] para nós que assumimos a responsabilidade de contribuir para a formação de psiquiatras, psicólogos clínicos, psicólogos sociais, etc., não devemos esquecer o seguinte: identificar basicamente o ato de ensinar e aprender como ato de inquirir, indagar ou investigar, caracterizando assim a unidade do ensinar-aprender, como contínua aprendizagem em espiral, onde em um clima de plena interação, professor e aluno - ou grupo - indagam, descobrem-se ou redescobrem-se, aprendem e se ensinam. A experiência demonstra que a situação em grupo é o melhor recurso para ensinar a psiquiatria. (SILVA C. opus. cit. p. 69).

O que essa experiência que "demonstra que a situação em grupo é o melhor recurso para ensinar a psiquiatria", pode ensinar a Escola? O que essas experiências em grupo podem ensinar aos que se ocupam da transmissão? Lacan também criou uma Escola cujo seu órgão de base para a transmissão era um pequeno grupo, mas a experiência mostra que o cartel é um fato de difícil acontecimento. Seria algo errado com o dispositivo? Ou o motivo seria a possibilidade de receber a transmissão por vias que exigem menos? Sabemos que na Escola pode-se receber a transmissão da teoria e da técnica pelos institutos, locais que oferecem seminários, cursos, etc. e na escola de Pichon, não há opção: forma-se através dos grupos operativos. O que isso pode nos ensinar?

\subsection{Grupos de Trabalho: abertura para novas possibilidades.}

Deve-se admitir que para aqueles que estão procurando respostas prontas e acabadas, o método de Bion era inexplicável, frustrante e irritante. (...) Os problemas estimulavam nele pensamento e discurso - nunca respostas. (BION F. 1992, p. 66)

Um outro funcionamento grupal contemplado nessa pesquisa foi extensamente estudado e analisado por Wilfred Bion (1897-1979), que não "fez escola”, como Pichon ou Lacan, mas, certamente, foi um dos principais responsáveis por muitas experiências em grupo que tiveram um olhar psicanalítico ${ }^{10}$. Ele realizou uma experiência bem sucedida com grupos na clínica Tavistok, em 1940, na Inglaterra para reabilitação de soldados que sofriam neuroses de guerra, resultando em algumas interessantes constatações sobre o funcionamento dos grupos, que o transformou numa autoridade sobre esse tema.

\footnotetext{
10 "Não posso ver qualquer justificação científica para descrever o trabalho do tipo que tentei como sendo psicanálise e já dei minhas razões para tal (...) de maneira que o termo psicanálise deverá continuar a ser aplicado, até onde possamos controlar a situação, aos seus princípios fundamentais”. (BION, ibid. p. 177)
} 
Resumidamente a experiência da ala de reabilitação, na qual Bion trabalhava, consistia em seguir um regulamento com os seguintes itens: todos os homens teriam que fazer uma hora diária de treinamento físico; todos teriam que ser membros de um ou mais grupos: artes manuais, cursos de correspondência do Exército, carpintaria, por exemplo; qualquer homem poderia formar outro grupo, ou por não existir um para a sua habilidade específica, ou por não sentir-se apto a participar de um dos grupos existentes; o homem que se sentisse incapaz de freqüentar seu grupo teria que ir para a sala de repouso, que deveria ser mantida tranqüila para a leitura, a escrita ou jogos tipo damas. Um enfermeiro seria responsável pela sala e deveria anotar o nome das pessoas que lá estivessem, por questão de rotina.

Quanto à rotina de intervenção de Bion, como responsável pela ala, consistia em supervisão e momentos de reflexão após a ronda que ele realizava com um ou dois homens, que costumava a retirar das suas atividades. Todos os dias eles teriam um encontro para divulgação de comunicados, orientação sobre outros assuntos da ala e para examinarem o funcionamento dos grupos. Numa dessas reuniões, Bion faz a sua primeira provocação, que faz com que a comunidade se torne mais auto-crítica e passe a gerenciar mais seu trabalho. Ele diz para o grupo que parecia estranho as pessoas não estarem se envolvendo nas atividades. Isso o lembrava de uma queixa que havia escutado na ala de treinamento, quanto ao "engodo", uma das suas objeções ao Exército e que a presença dele, "o engodo", na ala de reabilitação, era digna de reflexão. "Este comunicado deixou a audiência parecendo sentir-se como se houvesse sido 'apanhada"”. (BION, 1975, p.10).

Com a intervenção acima, ele trata de um assunto de responsabilidade comunal, que não concernia a ele, como oficial, sozinho. Uma estratégia de implicação, que o levará a inúmeras reflexões, já que as reações às suas intervenções eram bastante diversificadas e que demonstra a crença de Bion que "num tratamento do individuo, a neurose é apresentada como um problema do individuo. No tratamento de um grupo a neurose tem que ser apresentada como um problema do grupo". (ibid. p.3)

Neste período, Lacan entrou em contato com o trabalho terapêutico de grupos desenvolvido por Bion com soldados de guerra, relatado anteriormente. Ele demonstrou muito interesse na proposta de "alguém em que (...) brilha a chama da criação". Achou que ele lançou um "novo olhar sobre o mundo, que não se pode furtar facilmente". Qual seria esse novo olhar? Vale a pena nos determos nesse ponto, pela importância que esse olhar tem para o nosso estudo sobre os grupos e, em particular, sobre o cartel.

Partamos de um exemplo retirado da experiência observada: o desaparecimento de tesouras no grupo da clinica Tavistok, num momento em que ele já funcionava com 
autocrítica, organizando bem melhor a sua rotina. As salas andavam mais limpas, pelo aparecimento de uma faxina voluntária; novos grupos foram criados, dentre eles um de planejamento e outro de dança "que reerguia o sentimento de dignidade nos soldados". Contudo, ainda assim, havia os que "tiravam o corpo fora" e, um dia, as "tesouras de cortar couro desapareceram". Situações que geravam um protesto coletivo e faziam os homens "apelarem à autoridade".

Mas, toda vez que se recorria a sua intervenção, ele, Bion, com a paciência firme do psicanalista, devolvia a bola aos interessados: nada de punição, nada de substituição. Os vadios foram um problema proposto para reflexão tanto quanto a salvaguarda das tesouras de trabalho; na impossibilidade de resolvê-los, os mais ativos continuariam trabalhando pelos outros e a compra das tesouras seria feita às custas de todos. (ibid. p.115).

Podemos encontrar exemplos semelhantes na família ou nos grupos-classe. Existem "os que estudam menos", "os que cometem transgressões", "os que são mais indisciplinados" etc. Diante de uma situação difícil, um impasse, Lacan confirma a necessidade da resposta pautada na ética, expressa por Bion "não fazer da cura da neurose, responsabilidade dele": os mais ativos continuariam trabalhando pelos outros e a compra das tesouras seria feita às custas de todos. Um conceito de implicação no seu próprio sintoma, que a autoridade faz o outro ter, parece ser o novo olhar, nos convoca a ter.

Não sabemos ao certo se essa experiência influenciou a concepção dos cartéis feita por Lacan. Não há nenhuma referência explícita a isso na sua obra, exceto a menção feita por alguns colegas (DUNKER, 2004; GONÇALVES, 2004). Entretanto, existem alguns sinais. Verificaremos em seguida que membros em "pé de igualdade" era o que queria Lacan, na formação da sua Escola, em oposição à formação muito hierarquizada, oferecida pelos analistas didatas da IPA.

Relatamos anteriormente o impacto que a experiência observada na Inglaterra causou em Lacan e por fim, o significante "trabalho" encontra-se repedidas vezes na Ata de Fundação da escola de Lacan. Ora ele fala de tarefa, ora de execução de um trabalho e, por fim, termina com trabalhadores decididos. De qualquer modo, o que nos interessa destacar é o valor que é dado a uma demonstração de método, em plena conformidade com os primeiros avanços freudianos.

Sob o título significativo de (...) 'Tensões internas ao grupo na terapêutica. Seu estudo proposto como tarefa do grupo', os autores nos trazem de sua atividade num hospital militar um exemplo concreto, o qual, por esclarecer com um despojamento e, diria eu, uma humildade perfeita tanto a ocasião quanto as princípios, adquire valor de uma demonstração de método. Nele reencontro a impressão de milagre dos primeiros avanços freudianos: encontrar no próprio impasse de uma situação a força viva da intervenção. Assim é Bion, às voltas com 400 'aves raras' de um serviço dito de reeducação. (LACAN, 1947/2003, p.113). 
Um "reencontro da impressão do milagre dos primeiros avanços freudianos", que faz do impasse "a força viva da intervenção". Na Ata de Fundação da sua Escola, Lacan propõe o cartel para executar um "trabalho" de retorno à Freud, naquilo que Lacan supunha ser a verdade do inconsciente, a linguagem. Por meio da execução desse "trabalho" ele "queria restaurar a verdade" e "reconduzir à práxis original que ele (FREUD) instituiu sob o nome de psicanálise ao dever que lhe compete em nosso mundo; que, por uma crítica assídua, denuncie os desvios e concessões que amortecem o seu progresso, degradando o seu emprego".(ibid. p.235).

Essa foi a bandeira, que ele defendeu até o fim da vida. Se na sua origem o cartel era uma máquina de guerra contra o didata e a sua cambada, como expressa Lacan, com o seu estilo às vezes “ácido", em algum outro lugar (MILLER, 1994, p.14), aprimorando sua função ele se transformou em um meio de elaboração de um trabalho, uma forma de transmissão da psicanálise.

Bion, apesar da formação militar, não tinha uma bandeira para defender, tinha um desejo: introduzir conceitos novos "não perturbado por teorias anteriores" e a nosso ver e ao de outros autores (COSTA, 1989), foi bem sucedido. A sua estratégia foi comparar os fenômenos que observa nos grupos, com os mecanismos descritos por Melaine Klein (1931/1946), como típicos das primeiras fases da vida mental. Sua tese é de que, em contato com a complexidade da vida mental de um grupo, o adulto lança mão desses mecanismos que apontam para uma regressão maciça aos fenômenos da primeira infância. (BION, 1975, p.129).

Para ele, o núcleo da estrutura funcionando em um grupo não é a relação triangular, mas o sistema protomental, matriz “em que o físico e o psicológico ou mental são indiferenciados de onde partem as suposições básicas: dependência, acasalamento e luta e fuga”. (ibid. p.91). É dessa matriz, definida por Klein como constituída pela posição esquizoparanóide e pela posição depressiva, que partem as emoções próprias à suposição básica. Emoções que reforçam e ocasionalmente infiltram a vida mental dos grupos levando-os à crença de que há um grupo distinto de uma reunião de indivíduos e à fantasia de que o grupo vai fazer o individuo perder a sua distintividade.

Para Bion, qualquer grupo de indivíduos que se reúne para trabalhar e mostra um funcionamento adequado para promover a tarefa em execução, é denominado "grupo de trabalho". Esse conceito diz respeito, não às pessoas, mas à atividade mental de um certo tipo de grupo (ibid. p.131). As pessoas envolvidas em uma tarefa grupal mostram certa atividade 
mental dirigida à solução de problemas - incapacidade dos membros, neurose, indefinição profissional, por exemplo - com abordagem racional ou científica, e a aprendizagem pela experiência é facilmente aceita.

Após a intervenção sobre o "engodo" na clínica Tavistok, e a constante recusa de Bion em fazer da cura deles uma responsabilidade sua, aliada a sua forte determinação em não dar a solução para os problemas que os grupos enfrentavam, "ajudou a produzir, após vivida e saudável impaciência, uma crença real de que a unidade estava decidida a enfrentar a tarefa com seriedade científica”. (ibid. p.12) As reuniões diárias tornaram-se expressões, por parte de alguns, das suas capacidades em manter o contato com a realidade e a regular eficientemente as suas relações com os outros e com suas tarefas. O "engodo" transformou-se num grupo de trabalho, não refratário ao desenvolvimento e lugar onde as pessoas sofriam a exigência para cooperar.

Os requisitos para se atingir esse "bom espírito de grupo", são: ter um propósito comum; vencer um inimigo; nutrir um ideal ou uma construção criativa no campo das relações sociais; um reconhecimento dos limites do grupo e sua posição em relação a unidades maiores; flexibilidade; capacidade de absorver novos ou perder velhos membros sem perder a individualidade grupal; reconhecer o valor dos subgrupos para o funcionamento do grupo principal; valorização da contribuição de cada membro e respeito a sua liberdade de locomoção, limitada apenas pelas condições e regras aceitas pelo grupo; capacidade de enfrentar o descontentamento e possuir meios de tratar com ele; e por fim ter um tamanho mínimo de três membros ou mais que favorece a qualidade das relações, já que dois membros têm sempre relações pessoais. (ibid. p.18).

Naturalmente esse seria um bom funcionamento de grupo, entretanto as coisas não acontecem de forma tão pacifica. Bion pode constatar e demonstrar. Partiu de onde todos partiram: da constatação que todo indivíduo é impelido a buscar satisfação em grupo, mas, ao mesmo tempo, estar em grupo estimula e frustra. $\mathrm{O}$ fracasso em atender as exigências da tarefa ou uma atitude questionante do líder, "de quem a desgraça emana" (ibid p.150), tal como a esfinge do Édipo, mobiliza os sentimentos regressivos e gera um temor no grupo mais do que em qualquer outra situação, constatou Bion.

Esse temor, atribuído à proximidade das fantasias primitivas do indivíduo, e à interpretação vinda de alguém que é "suspeito liderar, mas raramente é visto como liderando" (ibid p.149), já que "nunca toma partido", "não diz nada”, gera uma forte ação defensiva no grupo. Nesses casos, as pessoas param de colaborar e passam a atuar por valência, palavra retirada da física, que representa nos grupos, reações de medo, agressividade, amor ou 
ansiedade, propagadas por contágio, numa combinação instantânea e involuntária. Elas passam a participar na atividade da suposição básica "sem treinamento, experiência ou desenvolvimento mental" (ibid p.141), que pode mudar freqüentemente, de uma suposição a outra, duas ou três vezes na mesma hora, ou o levar meses sendo dominado pela mesma suposição.

Cabe ressaltar diante do impasse que não era oferecida uma resposta técnica, como fazer dinâmicas de grupo, levar recurso áudio-visual, mas uma resposta ética. O "novo olhar", que Bion ensinou e Lacan nos convoca a ter. Certamente, essa ética não pode ser entendida por indiferença ou descaso com os problemas dos outras, mas o que esses dois psicanalistas nos convidam a olhar é que não há igualdade possível, em grupos heterogêneos, com distintos níveis de hierarquia. Bion lembra que a matriz básica protomental gera as reações primitivas e faz o indivíduo perder sua indistitividade no grupo e Lacan nos aponta para a prematuridade do organismo nas suas primeiras identificações:

O que há de surpreendente para nós em constatar que todo organismo social especializado, no caso os grupos, encontra um elemento favorável numa deformação específica do tipo individual, já que toda a nossa experiência do homem nos indica que são as próprias insuficiências da fisiologia que sustentam a maior fecundidade do psiquismo? (LACAN, 1947/2003, p. 117).

Insuficiências da biologia sustentando a fecundidade do psiquismo. Algo falta, é insuficiente, pode ser entendido pela linguagem, como vimos e pela prematuridade do organismo no momento da constituição do sujeito: o reconhecimento do eu em uma imagem, que não é igual a si mesma. Fato que marca posteriormente a impossibilidade da linguagem dizer tudo, ou a impossibilidade da relação sexual, impossibilidade de fazer um, com dois, ou de fazer o todo numa multidão.

[...] se dizemos que o neurótico é egocêntrico e tem horror a qualquer esforço de cooperação, talvez seja porque ele é raramente colocado num meio em que todos os membros acham-se no mesmo pé que ele no que concerne às relações com o seu semelhante. (ibid. p.116).

Os exemplos nos são fornecidos por Bion. Os grupos que antes funcionavam de forma colaboradora, em torno de uma tarefa, deixam de atuar de forma cooperativa e começam a achar que devem ser sustentados por um líder de quem dependem para a nutrição - tanto material, quanto espiritual - e proteção, funcionando com a suposição básica de dependência.

Nessa atividade, caso seja solicitada a realização de uma tarefa que exija a consciência de tempo, será fortemente incompreendida, poderá ser rejeitadas ou gerar sentimento de 
perseguição, característica que pode ser encontrada neste ou nos demais grupos de suposição básica. Verificamos esse fenômeno em algumas reações de alunos em sala de aula: "não sabia que era para hoje", "você não disse nada sobre a data de entrega" ou então, "você está me perseguindo, não gosta de mim”.

Neste tipo de agrupamento o líder torna-se a divindade do grupo, as perguntas lhe são dirigidas na suposição de que ele sabe as respostas. "O grupo de dependência cedo mostra que uma parte integrante da estrutura é a crença na onisciência e onipotência de um determinado membro do grupo" (BION, 1975, p. 89) que marca a ausência de um desejo de desenvolvimento em cada um dos membros.

Alguns grupos já são formados com essa suposição, como por exemplo, o grupoclasse e os grupos de estudo. Muitas vezes em grupos atuando sob a suposição básica de dependência, quando não se formam subgrupos, que atuam como oposição, como nos gruposclasse, confirma-se uma disciplina, limitando-se a conversa a tópicos que são importantes e que apóiam a visão de desigualdade de posições. São grupos centrados em torno da figura do coordenador, o líder, para quem os olhares e comentários são dirigidos e a quem se supõe um conhecimento maior do assunto estudado.

Bion afirma que nessas relações cria-se uma "estrutura refinada", uma sensação que a situação é familiar e imutável, de um lado, alguém que sabe e de outro, alguém que está em uma condição de dependência, tal como o filho em relação a seus pais, o paciente em relação ao seu médico. Estrutura que pode ser facilmente derrubada, primeiro, porque apesar de depender, não se confia que o outro saiba exatamente o que faz; também porque reações emocionais como ódio, ciúmes, ressentimentos são prontamente evocadas.

Os indivíduos em grupos como este só acham que estão sendo bem tratados quando falam com os líderes do grupo. Muitas vezes chegam com declarações preparadas e não é freqüente terem a sensação de pedir demais e receber muito pouco, ou que estão sendo enganados, que progridem em um ritmo muito lento. A característica deste tipo de grupo, de exaltação de uma pessoa, cria dificuldades para o ambicioso ou para qualquer um que queira ser ouvido, porque aos olhos de um, ou de todos, essa pessoa encontra-se em posição de rivalidade com o líder.

As características de grupos de suposição básica de dependência citadas por Bion são: imaturidade nas relações individuais; ineficiência nas relações de grupo; temor de tornar-se a virtude suprema; elevação da capacidade de fuga instantânea, assim que qualquer indivíduo experimente medo; incapacidade de acreditarem que podem aprender uns com os outros e 
geralmente acham que suas experiências são insatisfatórias, jogam suas preocupações sobre o líder e esperam que este solucione todos os seus problemas.

Apesar de ser colocado neste lugar, aquele que teria as respostas, na maioria dos grupos em que participava Bion questionava e não atendia a demanda, pois, sabia que este estado de coisas é muito desagradável para adultos "plenamente desenvolvidos" e também porque sabia que o grupo não estava interessado em compreender o que tinha de importante no que ele dizia, mas sim de utilizar apenas aquelas partes da sua contribuição que pudessem se tornar naquilo que parecia ser um corpo de crenças bem estabelecido para cada um deles. "Gestos, tom de voz, maneira, aparência, assunto, nada é perdido se puder ser encaixado naquele sistema". (ibid. p.74).

O silêncio, além de negar ao líder material para "investigação científica", expressava devoção ao líder, temor reverencial, mais do que pausa para pensar. Nisso se aproximavam das comunidades religiosas com as exigências que se fazem aos seus fieis: repressão ao pensamento independente; caça às heresias, a rebelião; produção de material para sustentar a opinião que sua filiação ao grupo de dependência, como os de uma seita religiosa, exerce influência ampla sobre suas vidas mentais, para citar alguns. "O grupo, como grupo, opõe-se à idéia de reunirem-se para trabalhar e, reage como se algum principio fosse infringido se tivesse que fazê-lo", como disse Bion "um ódio ao desenvolvimento", e uma "falta de consciência de tempo", duas características comuns em todos os grupos de suposição básica..

Verificamos freqüentemente isso nos grupos-classe e nas instituições. Nos primeiros, os alunos acham que permanecem na escola tempo demais, sempre esquecem o que viram na aula ou no ano anterior, parecem não ter aprendido nada. Não querem estudar e tiram vantagens disso. Verificamos isto nas frases: "não estudei nada, mas tirei nota boa!" ou “passei sem saber nada!”. Tal como o herói que nunca faz nenhum trabalho, mas se encontra sempre no auge da forma, nos lembra Bion.

Nos grupos institucionais, compostos de pessoas mais velhas, a suposição básica de dependência pode ter uma outra característica. Ela pode ser manifestada num apego excessivo às idéias preestabelecidas ou à uma determinada teoria, transformando-as em bíblia. Nesses casos, quaisquer idéias novas, que vise um desenvolvimento ou mudança, são vistas como ameaça e são recebidas com forte oposição. Mesmo mais velhos, muitos se opõem as "dores do desenvolvimento".

Se o desejo de segurança fosse tudo o que influencia o indivíduo, então o grupo de dependência poderia bastar, mas o indivíduo precisa mais do que segurança para si e, dessa maneira, tem mais necessidade de outras espécies de grupos. Se o individuo estivesse preparado para suportar as dores do desenvolvimento e tudo que isso implica em esforços para aprender, poderia ultrapassar o grupo de dependência. Mas 
o fato de desejá-lo (...) sem passar pelas dores de crescimento (...) resulta num impulso na direção de um grupo estruturado para o acasalamento ou para luta e fuga. (ibid. p.82).

Esse tipo de grupo de suposição básica, o acasalamento, tem como principal característica um "ar de expectativa prometedora", uma expressão verbal em idéias tais como: o casamento porá fim às necessidades neuróticas; a terapêutica de grupo revolucionará a sociedade; a estação vindoura será mais agradável; uma nova comunidade deverá ser desenvolvida. Exemplos fornecidos por Bion aos quais acrescentamos outras expectativas contemporâneas: que o investimento na educação acabará a violência; que os treinamentos vão revolucionar as empresas, etc.

Todas idéias otimistas, racionalizações destinadas a efetuar um deslocamento no tempo e uma transferência de sentimentos de culpa, ódio, destrutividade e desespero para sentimentos moralmente inobjetáveis. Todavia, "para que esses sentimentos de esperança sejam sustentados, é essencial que o líder do grupo, (...), seja futuro - ele deve ser uma idéia ou uma pessoa que salvará o grupo." A fim de realizar isso, evidentemente, a esperança messiânica nunca deve ser alcançada. Sabemos que "apenas quando permanece uma esperança, é que a esperança persiste" (ibid. p. 139).

Dizendo de outro modo, ele demonstra que esse tipo de grupo precisa da criação de um Messias, seja ele pessoa, idéia ou utopia. Com essa forma de funcionamento, com essa suposição básica, nada se faz no presente, espera-se algo de bom aconteça no futuro. Quando, ainda assim, as pessoas produzem algo, afirmam que não foi para elas, que "foi para as gerações futuras", para o "benefício da humanidade", etc.

Nesses grupos os estímulos ao desenvolvimento defrontam-se com uma reação hostil, as pessoas se recusam a ter insight e participam dos grupos como espectadores. Com entender isso? Em alguns grupos, o sexo, metaforizado na relação estabelecida entre dois membros, ocupa uma situação central, que faz o grupo viver momentos de tensões, reagir de forma cansativamente errática, com um padrão característico da suposição básica de acasalamento, que foi descrito por Bion assim:

[...] dois membros envolviam-se em uma discussão; às vezes as trocas de palavras entre eles mal podiam ser descritas, mas era evidente que estavam envolvidos um com o outro e que o grupo, como um todo, pensava assim também. Nessas ocasiões, o grupo ficava sentado em silêncio atento, comportamento bastante surpreendente, tendo em vista a impaciência do neurótico com qualquer atividade que não se centralize em seu próprio problema. (ibid. p. 53). 
Ele constatava que sempre que duas pessoas, independente do sexo biológico, começavam a manter esse tipo de relação no grupo, essa relação estava sustentada, pelo par interessado e pelo grupo, na relação sexual. Nesse tipo de agrupamento, o Messias, ou a idéia messiânica, ocupa um lugar central, o de precursor do desejo sexual, e a ligação entre os indivíduos, é libidinosa, remete ao casal parental que os filhos passivamente observam com idéias de procriação e nascimento.

A ansiedade nesse tipo de grupo impele a busca de aliados, mas seguindo o raciocínio do autor, não tardará para que o grupo desenvolva cisma ou oposição, quando o desenvolvimento é exigido do grupo e das pessoas que o compõem. Sofrendo essa transformação a ansiedade passa a assumir a forma do grupo luta-fuga, ou seja, "a libertação de ódio que encontra um escoadouro em ataques destrutivos a um suposto inimigo ou numa fuga ao objeto odiado". (ibid p.151).

No grupo de suposição básica de luta e fuga as exigências do líder sobre o grupo são sentidas como concedendo oportunidades para a fuga ou agressão. Se ele fizer exigências que não essas, será ignorado. "Tentativas de esclarecer o que está acontecendo são obstruídas pela facilidade com que se obtém apoio emocional para tais propostas, segundo expressem ódio a qualquer dificuldade psicológica ou, alternativamente, o meio pelo qual se pode dela escapar". (ibid p.140-1).

Verificamos isso com muita frequiência em grupos de jovens na escola ou dentro de um grupo-classe. Representados em frases como: "nós somos melhores, que a classe ao lado"; "nosso grupo é mais inteligente, mais preparado", ou seja, o inimigo é o outro, aquele que precisa ser combatido, superado, humilhado. Nos grupos terapêuticos qualquer tentativa de esclarecimento do que esta acontecendo é obstruída pela facilidade com que se obtém apoio emocional para sua proposta caso expressem ódio a qualquer dificuldade, ou meio pelo qual se possa fugir dela.

Bion constatou com as suas experiências com grupos que qualquer suposição básica, luta-fuga, acasalamento ou dependência, podem atuar isoladamente e aparecer a qualquer hora nos grupos, às vezes passando de uma para outra em questão de horas ou permanecendo por meses atuando no grupo. Ele também aponta a possibilidade de formar-se um grupo, atuando com uma determinada suposição básica, dentro de um grupo maior, mesmo que este esteja atuando como um grupo de trabalho.

Em um subgrupo atuando com a suposição básica de dependência, uma determinada pessoa, que faz parte dele, ocupará o lugar do líder das demais, que se submeterão a sua influência. Caso o subgrupo seja uma formação de acasalamento, esse subgrupo atuará 
ajudando os seus membros a entender que a idéia nova trazida pelo grupo maior é uma idéia que eles já estavam familiarizados, que já sabiam do que se tratava, muito antes de ter sido afirmada. Por fim, quando o subgrupo está organizado pela suposição básica de luta-fuga ele provocará, muitas vezes, de forma manifesta, reações contra a idéia nova.

Qual seria o tamanho ideal de um grupo para que haja mais transmissão, mais trabalho e menos efeitos imaginários? Nossa experiência tem demonstrado que a formação de subgrupos dentro de um grupo de trabalho geralmente acontece em agrupamentos mais numerosos: como em grupos escolares ou grupos de formação de professores, por exemplo. Seria essa a razão que levou Lacan a restringir o cartel a cinco pessoas mais-uma, o que resulta em seis pessoas, no máximo?

Baseado em sua experiência, Bion defendia que os grupos com menos de três pessoas, transforma-se em um par, numa relação dual, com todos os efeitos que vimos acima; com num maior número de pessoas, por sua vez, "há mudança de qualidade na relação interpessoal" (ibid p.18). Entretanto, nas obras que consultamos, não achamos nenhuma referência a um "número ideal” de participantes em um grupo para que esses fenômenos não ocorressem. Contudo verificamos que, além da experiência realizada na clinica Tavistok, ele conduzia grupos de aproximadamente 20 pessoas, de onde retira as constatações sobre as suposições básicas.

A metodologia utilizada para operar nesses grupos, sejam eles de dependência, acasalamento ou luta e fuga, não tem nenhum referencial ou escala como a que existe nos grupos operativos. Devido a sua formação kleiniana, suas intervenções estavam fundamentadas na teoria da identificação projetiva, por isso, ele defendia fortemente a necessidade da análise do analista na clínica ou nos grupos, pois, estes "não possuem nenhum sistema coordenado como os geógrafos e operam com os sentidos e percepção".

Para ele, o analista é aquele que deve ter uma mente aberta para o novo e interpretar a partir dos seus sentimentos a respeito de um padrão que se repete o que resiste à mudança, aquilo que está relacionado com a mentalidade, "expressão unânime da vontade do grupo" e a cultura do grupo, "função do conflito existente entre os desejos do indivíduo e a mentalidade do grupo" (ibid p.57). Ele não faz isso por onipotência, por que tem o saber, mas o faz para limitar um espaço, para tentar traduzir o que supõe ser a atitude do grupo para com os outros e para consigo. No que essa postura pode ser aproximada a do professor, orientador ou coordenador de um grupo, aqueles que são colocados ou se colocam como grandes conhecedores de um assunto? 
A posição de autoridade, o status que lhe atribuíam como grande conhecedor do funcionamento dos grupos gerava uma expectativa que Bion não respondia. "A cura do outro não é responsabilidade minha, só sou responsável pela minha própria cura e pelo meu sintoma", dizia ele. Ele não correspondia à demanda do individuo em colocá-lo na posição de autoridade, baseado e sustentado pelas suposições básicas: luta e fuga, acasalamento e dependência. Não estabelecia regras de procedimento, não adiantava nenhuma agenda. Sua metodologia consistia em persuadir o grupo a fazer o estudo das suas próprias tensões - essa era a tarefa grupal e podemos aprender com ele.

Essa posição estava relacionada com a sua crença que "a resposta é a doença da questão", frase de Blanchot, várias vezes mencionada por ele. As respostas são tapa-buracos, elas põem fim à curiosidade. Para Bion não há verdade absoluta. Ele não se sentia confortável em ser denominado kleiniano e achava que cada um deveria encontrar o seu vocabulário. “Isso pode servir para eles, mas não serve para mim”. No fragmento abaixo vemos como ele defendia a diferença de visões e a não uniformidade do pensamento, já que qualquer definição que evita ser vaga, torna-se dogmática.

Tornamo-nos conscientes de uma mente, ou pensamos estar conscientes dela, e construímos uma vasta superestrutura de teorias sem nenhuma consideração real sobre o que é uma mente ou personalidade. Aprendemos essas teorias - a de Freud, Jung, Klein - e tentamos trazê-las absolutamente rígidas como que para evitar ter que continuar pensando. Só que não podemos fazer uma tentativa consciente e deliberada de ajudar o processo de desenvolvimento caso o nosso inicio seja estar fossilizado mentalmente. (BION, 1992, p.14).

Klein era suficientemente dogmática: "a criança evacua partes indesejáveis de sua personalidade e as lança nas outras pessoas" (ibid. p.111). Bion não achava tão simples assim. Ele pensava que devia haver alguma realidade que correspondesse ao sem sentido da psicanálise, pois entendia a "linguagem fundamental" (o inconsciente), como ambígua, não dogmática, sem sentido e capaz de gerar impulsos poderosos.

\footnotetext{
Tenho que tolerar o fato que; espera-se que eu esteja consciente de que tenho lá determinados elementos sobre os quais nada posso fazer, a menos que eu vá a um analista e nós tentemos lidar com a coisa. É uma questão de tornar proveitoso m mau negócio - esse mau negócio que acontece comigo. Não posso ser analisado por completo - não acho que isso exista. Algum dia tem que parar, depois disso vou ter que fazer daquilo que sou o melhor que puder. (ibid. p. 111).
}

Saber dessa "linguagem", a do inconsciente, que não se sabe bem o que é, mas que se sofre os efeitos, abre espaço para crescimento e desenvolvimento, pois ela abre inúmeras possibilidades. Não é o mesmo que uma rede física de comunicação, onde existe um estimulo $\mathrm{X}$, demandando uma resposta $\mathrm{Y}$. Uma rede de comunicação verbal nos ensina que um estímulo X pode demandar inúmeras respostas, dentre elas algo novo, nunca pensado. Essa 
abertura para novas possibilidades, inerentes a própria linguagem, não é o que deveria configurar o analista, o professor e o pesquisador reflexivo $?^{11}$

Podemos encontrar um exemplo disso nos dois campos estudados. Em um deles, no campo analítico, os analisandos vão procurar um analista supondo que ele saiba a resposta para suas questões - buscam a resposta para preencher o vazio, mas essa não é dada facilmente, apesar do analista ficar um bocado tentado e contente em condescender. É difícil resistir a isso. Mas, caso o faça, pode também afogar toda curiosidade e fechar todo o processo de investigação. (ibid p.34) $\mathrm{O}$ mesmo acontece com o professor, ou qualquer autoridade, que rapidamente dá uma resposta para as questões dos integrantes do grupo.

$\mathrm{Na}$ clinica, Bion nos lembra que é importante trabalhar com base no fato que "o melhor colega que você jamais poderá ter - além de você - não é um analista ou um supervisor ou seus pais: é o paciente; esta é a única pessoa que você pode confiar que está de posse do conhecimento vital. A única coisa que não sei é por que ele simplesmente não faz uso desse conhecimento" (ibid. p. 95). Mas ele sabe que o "ser humano é um animal que depende de um par", a unidade biológica é um casal, na análise estabelece-se um par temporário.

Nesta relação dual, Bion diz que o que importa é o modo como se fala com o paciente e que a experiência mostra que vale a pena ter respeito por si mesmo, por aquilo que se pensa, imagina, especula. Do casamento do sentimento (intuição cega) com o pensamento (conceito vazio) pode surgir um pensamento maduro completo que se traduza em uma interpretação que favoreça o paciente a fazer uso de seu conhecimento. (ibid. p.98)

E na escola? Como se daria isso? As relações entre o professor e o aluno, na maior parte de vezes, não é dual. Vimos que ela se dá entre o professor e o grupo-classe. Neste campo, o educacional, muitos alunos também não fazem uso do "conhecimento vital", a capacidade para aprender, inerente a todo ser humano. Por que isso? Seria uma demanda de estabelecimento de uma relação dual? Seria por isso que muitos atuam na classe para chamar atenção, para que os professores aprendam os seus nomes? Os destaquem do todo do grupo? Isso favorece a aprendizagem? Que tipo de abordagem, que tipo de comunicação deve ter um professor com seus alunos? Pergunta sobre a técnica que Bion responde com ética direcionada para os pais, de forma específica, mas que pode ser ampliada para posterior análise das vicissitudes de aprendizagem encontradas nos dois campos estudados.

\footnotetext{
11 , "Se os tempos passam, a gente fica mais velho e se as nossa idéias continuam as mesmas, deve haver algo errado" (ibid. p.112)
} 
É muito difícil dizer (...) a quem temos esperança de educar, o que temos que fazer? A única coisa que parece ser básica, não é tanto aquilo que fazemos; mas aquilo que vivemos a; aquilo que somos. É por isso que digo que os pais sejam capazes daquilo que eu chamo de amor ardente. Aí então a criança tem a chance de aprender algo a partir do modo como os pais se comportam. Nada em sua educação escolar, nem em qualquer outro lugar, pode lhes ensinar isso. (ibid 46)

A resposta de Bion à difícil pergunta do que fazer com os que temos esperança de educar "única coisa que parece básica é a capacidade de amor ardente" nos remeteu a tese central da teoria freudiana de que a sexualidade tem um tal poder de coerção sobre a vida humana que só uma força de igual porte, a ameaça de morte ou a culpabilidade pelo assassinato, pode contê-la. Só uma força de mesma proporção pode barrar os excessos narcísicos, pode conter essa força disruptiva, que busca satisfação absoluta a qualquer preço e tem horror ao desenvolvimento. A resposta nem sempre foi a mesma. Em Totem e Tabu, o instrumento de controle, era a promessa de morte; na Psicologia das Massas, a promessa de amor: "sabemos que o amor impõe um freio ao narcisismo, e seria possível demonstrar como, agindo desta maneira, ele se tornou um fator de civilização" (FREUD, 1921/1969, p.157).

\footnotetext{
Somos de opinião, pois, que a linguagem efetuou uma unificação inteiramente justificável ao criar a palavra 'amor' com seus numerosos usos, e que não podemos fazer nada melhor senão tomá-la também como base de nossas discussões e exposições científicas. Por chegar a essa decisão, a psicanálise desencadeou uma tormenta de indignação, como se fosse culpada de um ato de ultrajante inovação. Contudo, não fez nada de original em tomar esse amor em sentido 'mais amplo'. Em sua origem, função e relação com o amor sexual, o 'Eros' do filósofo Platão coincide exatamente com a força amorosa, a libido da psicanálise, tal como foi
}

pormenorizadamente demonstrado por Nachmansohn (1915) e Pfister (1921), e, quando o apóstolo Paulo, em sua famosa Epístola aos coríntios, louva o amor sobre tudo o mais, certamente o entende no mesmo sentido 'mais amplo'. (ibid. p.116).

Os pais, os educadores, estes a quem as pessoas devem temer ou amar, são desde sempre e para sempre elementos que não pertencem à classe lógica dos elementos, os membros dos grupos. Em linguagem freudiana, "ele fica a parte do todo, ocupando o lugar Ideal, de onde emana a ordem para o Ego recalcar essa ou aquela representação pulsional”. Um líder que fica a parte do todo é um a mais no conjunto. Que função deve ter esse mais-um no pequeno agrupamento chamado cartel? O que esse agrupamento pode nos ensinar? 


\title{
2.3. Cartel: uma proposta para a transmissão.
}

Este tipo de funcionamento em grupo, esse dispositivo, foi proposto por Jacques Lacan (1901-1981) fundação da sua Escola em 1964, declarado e descrito com suas próprias palavras:

\begin{abstract}
Aqueles que vierem a esta escola se comprometerão em realizar uma tarefa submetida ao controle interno e externo: os que assim se comprometerem podem estar seguros de que nada será economizado para que tudo o que façam de valor tenha difusão merecida no local mais conveniente. Para a execução desse trabalho adotaremos o princípio de uma elaboração sustentada dentro de um pequeno grupo: cada um deles (nós temos um nome para designar esses grupos) se comporá de pelo menos três pessoas e de no máximo cinco, sendo quatro o tamanho ideal. Mais-um, encarregado da seleção, da discussão e da saída a dar ao trabalho de cada um. (LACAN, 1964/2003, p.235).
\end{abstract}

Assim começa a Escola de Lacan, com uma aposta, uma proposta de trabalho e transmissão da psicanálise, que não é de ensino. Este que "só pode transmitir-se de um sujeito ao outro pelas vias da transferência de trabalho" (ibid, p.242). Uma "invenção" que não pode ser dissociada do contexto histórico no qual surgiu. $\mathrm{O}$ trabalho com grupos pequenos era a ordem do dia na França dos anos 60. Na Sorbonne, os estudantes de Letras organizavam o GTU, Grupos de Trabalho Universitário, "convidando os estudantes a trabalharem juntos, numa base igualitária, sem 'profs', ou com o mínimo possível de 'profs', maneira de fazer oposição ao curso magistral, prática tida como reacionária. É como se houvessem nessa proposição, os pródromos de maiôs de 1968”. (MILLER, opus cit. p.12).

O cartel é uma proposta anti-autoritária, uma proposta de transmissão em um grupo pequeno que admite um líder, como toda formação grupal, mas um líder reduzido ao mínimo, reduzido a uma função. Lacan vivia na época uma exclusão da comunidade psicanalítica, por criticar a análise didática como única possibilidade para a formação dos analistas e também por não seguir as orientações da sociedade quanto ao tempo das sessões. A IPA, "herdeira" sociedade fundada por Freud, tinha regras muito rígidas e padronizadas e uma estrutura de ensino piramidal, centrada nas figuras carismáticas, que ensinavam a psicanálise através de exposições teóricas ministradas em cursos ou seminários. ${ }^{12}$

\footnotetext{
12 "A IPA permanece, hoje me dia, como um Comitê burocrático e centralizado, que deve a sua unidade à imposição de certo número de regras padronizadas e a um sistema jurídico preciso, que esvaziou o freudismo de sua substância. Essa internacional extrai o seu poderio de sua história: foi criada por Freud e com o apoio dele, ainda que Freud nunca tenha assumido o seu comando. Totalmente diversa é a Internacional lacaniana: não é a obra do mestre, mas de seus herdeiros, de sua família". (ROUDINESCO, 1988, p.744). Movimento expansionista da psicanálise, iniciado após a morte de Lacan, no inicio dos anos 80, que deu origem a AMP (Associação Mundial de Psicanálise). A bandeira que carregam é "reconquista do campo freudiano". Uma "batalha", que "visa sobretudo a impedir a IPA de se apoderar da doutrina de um mestre morto cujo ensino ela rejeitou durante a sua vida" (ibid.)
} 
A excomunhão Lacan da Sociedade se de deu no fim dos anos cinqüenta, mas muito antes disso, já podíamos notar na sua escrita crítica, questionamentos de saberes que propagam a ilusão e a submissão. Ele era um participante ativo de grandes aventuras culturais que interessavam a vanguarda literária e os grandes debates. "Jacques Lacan foi o único, na França, a restituir essa feição à descoberta vienense. Deveu esse papel a sua genialidade pessoal, mas também ao caráter surrealista e kojeviano de seu romance na juventude" (ROUDINESCO, 1988, p.743).

Com essa postura e em "defesa" da psicanálise freudiana, Lacan fez Escola se tornou uma autoridade no campo psicanalítico referencia para muitos analistas. Ele tem uma visão particular do coletivo e individual que pode contribuir para aqueles que atuam no campo educacional ou vivendo em grupos. Entretanto, seu estilo de escrita é difícil, estratégia discursiva que lhe agrada, por nos obrigar um esforço maior para apreender e transmitir das suas idéias. Sabemos que estaremos sujeitos a distorções, próprias da transmissão da linguagem, mas também sabemos que, no intervalo de uma idéia e outra, talvez possamos produzir algo novo.

O cartel é um pequeno grupo esvaziado de identificações verticais e horizontais, com um líder reduzido a uma função com poder de intervenção direcionando para a produção de um trabalho ao final. Lacan inova no campo com uma proposta de trabalho de investigação em pequenos grupos, com duração definida, e não uma proposta de aulas expositivas, seminários, conferências, cursos, etc. Estes, se existirem, devem ser ministrados fora da Escola em Institutos criados para esse fim, ou como ele fazia, por conta e risco, em auditórios de Faculdades ou Hospitais, depois de ter sido expulso da IPA.

Nessa Escola, além deste caráter investigativo, conceitual, a idéia de cartel parte de uma determinada concepção da formação do analista: a de transformar uma transferência dirigida a alguém que sabe e a quem se pede que ensine numa transferência de trabalho, quer dizer, num desejo de produzir saber sobre a psicanálise e fazê-la avançar. "A Causa Freudiana não é Escola, e sim Campo - onde cada um terá liberdade para demonstrar o que faz com o saber que a experiência decanta" (LACAN, 1981, p.50).

Como dissemos no inicio o entendimento dos cartéis não vai sem o entendimento da Escola que Lacan concebeu. Inicialmente, desde Freud a formação do analista nuca se deu em uma Universidade, apesar de pressupor que o candidato tenha um diploma de nível superior, não restritivo ao dado pela medicina ou pela psicologia. Ela não se faz em um banco de Universidade com a leitura e o estudo dos textos sobre a psicanálise. 
A formação de um analista se dá fundamentalmente na sua própria análise, no divã, a psicanálise em intensão. Mas esta apenas não é suficiente. É necessário que ele estude a teoria, que domine seu léxico e principais pressupostos. Para isso ele deve se engajar nestes pequenos grupos denominados cartéis e participar dos seminários oferecidos pelas instituições psicanalíticas, não pela Escola, sobre filosofia, lógica, literatura, religiões, recomendações freudianas adicionadas à necessidade do analista ter uma vasta cultura.

Geralmente o movimento de alguém que ainda não sabe sobre determinado assunto é de procurar alguém que saiba um pouco mais que ele para lhe ensinar - "transferência dirigida a alguém que sabe e a quem se pede que ensine", uma suposição básica de dependência, freqüente nas escolas regulares. A psicanálise nos ensina que este não é o melhor método para aprender. Aprende-se mais aquele que tem uma dúvida sobre determinado ponto e se lança em uma pesquisa em busca do saber sobre a verdade, que para a psicanálise tem relação com o impossível $^{13}$. Nesta concepção de escola, transforma-se a transferência dirigida a alguém que sabe, em transferência de trabalho, que acontece nos cartéis e nas instituições.

O nó borromeano, como escritura, dá suporte a essa estrutura do cartel e da identificação do sujeito e do grupo, como vimos no capítulo um. Ele amarra três funções discursivas, que presidem a realidade psíquica e estão enlaçadas de modo borromeano - o que implica em igualdade de posições, mas sem amarração solidária, pois soltando-se uma, não importa qual, todo o conjunto se desfaz. Duas delas o imaginário e o simbólico, instrumentais que podemos lançar mão para abordarmos a realidade e o real o campo onde isso se dá. No centro, encontra o objeto a, aquilo que está no interior de cada um, que compõe o grupo. A identificação com uma falta. A falta de saber, laço de identificação entre os membros.

Por conter essa propriedade borromeana e não ter uma forma ideal de enlace, o objeto a está no centro, não o líder. Não se trata de um modelo. Nós pensamos que Lacan o utilizou como metáfora. No inicio da sua Escola, quando a sua formalização ainda não era precisa, alguns pensavam que cada um dos integrantes ocuparia a função de uma dessas instâncias. Mas certamente não é disso que se tratava, nem é disso que se trata. (LACAN, 1975) Tal como um sujeito constituído pelo real, simbólico e imaginário, o cartel também está sujeito aos efeitos dessas instâncias, até a sua dissolução, que não deveria passar de dois anos.

\footnotetext{
${ }^{13}$ Para Lacan a verdade é um lugar e não um termo no discurso, como lugar ela jamais pode ser toda dita, por que ela é não-toda. De um outro modo, não se pode dizer toda a verdade e que esse é o seu caráter de impossível, real, o que não cessa de não se escrever, ou seja, não há verdade accessível, ou como as próprias palavras de Lacan, "a verdade não é outra coisa senão o que o saber só pode aprender que sabe ao por em ação sua ignorância", (ibid. p.813).
} 
Esse grupo deve ser composto de "ao menos três pessoas e de no máximo cinco, sendo quatro o tamanho ideal. Mais-um, encarregado da seleção, da discussão e da saída a dar ao trabalho de cada um". A quantidade de pessoas estabelecida por Lacan não nos parece ser normativa. Na aula de 17 de janeiro de 1978, ele recorreu a intervenção de Soury para tratar essa questão. Na matemática o número zero é neutro ou degenerado, que quer dizer, não engendra nada novo. Qualquer número adicionado a ele não gera outro. A cadeia de dois círculos ocupa o mesmo lugar que o zero. Não se pode obter nenhuma cadeia, sobretudo borromeana, a partir de dois círculos. Ela própria não tem a propriedade borromeana. Em contra partida, com o número um pode-se obter todos os números e a partir da cadeia de três círculos, enlaçadas borromeanamente, se obtém novas cadeias com igualdade nas posições, já que se cortando um todo o conjunto se desfaz.

Três era a medida certa para formar pela estrutura, menos que isso virava um par, mas que cinco uma multidão. Só num pequeno grupo, como três, cada um leva o seu nome. Numa comunidade muito numerosa prevalece o anonimato, apenas o líder é reconhecido, para Lacan o objeto dessa comunidade não é o mesmo que interessa a prática analítica. Entretanto, só a comunidade Cristã deu conta que não havia Deus sustentável que não fosse tríplice. Lacan reconhece que nunca se deu nenhuma justificativa para essa trindade, mas que seu nó de três “dá uma forma do que se poderia denominar seu real”. (1975, p.112).

Para ele a tarefa de um grupo muito amplo comporta limitações tais , que não há como se esperar progresso em condições tais. Mais resta ainda a questão de por que $4+1$ ser o número ideal. Com todos os efeitos de suposição básica que aprendemos anteriormente. Não seria a cadeia 4+1 ideal, por deixar o mais-um de fora dos pares, que inevitavelmente se formarão nos cartéis? Isso não aconteceria nos agrupamentos de $3+1$, nem de $5+1$. Nesses, ninguém ficaria "de fora" dos possíveis "acasalamentos" que se formariam.

Algumas pessoas se reúnem por afinidade ou por terem um interesse em um determinado tema. Definido o tema, passam para a escolha do mais-um, aquele que fará o grupo trabalhar, tentando reduzir os efeitos imaginários abordados no capítulo um e favorecendo que todos, a partir de uma questão individual sobre o tema em comum, escrevam um artigo sobre o que descobriram, que conclusões chegaram ou mesmo apenas relatem os impassem desta experiência.

Essa escolha geralmente se dá também sobre efeitos imaginários. Os envolvidos na proposta elegem uma pessoa que supõem um determinado saber sobre o tema e que esteja a altura de ensiná-los. Caso o mais não esteja advertido, o mais-um responderá deste lugar e muito facilmente criará um grupo de suposição básica, onde os efeitos serão devastadores e 
certamente encontrará dificuldades para fazer com que todos estejam na posição de produzir um saber sobre a sua questão.

Lacan foi preciso quanto descrevia o lugar do mais um em vários momentos que falava do cartel. Em um dos seus escritos, $O$ número treze e a forma lógica da suspeita, (1945/2003), ele parte de um problema aritmético para demonstrar demonstra a lógica que reside por trás da escolha desta pessoa e que está presente na lógica do coletivo.

\footnotetext{
A forma aqui desenvolvida, embora compare a sucessão, não é da ordem do tempo lógico (...) ela faz parte de nossas abordagens exemplares para a concepção das formas lógicas em que se devem definir as relações do indivíduo com a coleção, antes que se constitua classe, ou seja, antes que o individuo seja especificado. (ibid. p. 92).
}

O problema consiste no seguinte: em doze peças de aparência semelhante, uma distingue-se por uma diferença de peso, imperceptível sem um aparelho de medição, diferença esta sobre a qual não se diz se é para mais nem para menos. (ibid. p. 91) Solicita-se que se encontre essa peça entre as demais em um total de três pesagens.

Essa lógica evidencia que o indivíduo portador da diferença ambígua, não sabemos se para mais ou para menos, é único, a aparência semelhante desta peça é ligeiramente diferente quanto ao peso. "Aqui tocamos numa dialética essencial das relações do individuo com a coleção, na medida em que elas comportam a ambigüidade do a mais ou a menos" (ibid. p.94).

Só ele, dentre todos, tem um peso diferenciado. A lógica defendida para resolver este problema é a posição por-três-e-um, que consiste na pesagem das três peças suspeitas com uma peça boa. Uma pesagem desta forma, com uma peça-padrão, disposta desde o início, "permitirá introduzir a posição por-três-e-um desde a primeira pesagem e aumentará em uma unidade o grupo incluído nesta. Ora, o dado dessa peça, que parece de tão grande valor para a nossa intuição, formada na lógica classificatória, não terá absolutamente nenhum outro efeito", (ibid. p.104) que permite evidenciar que a uniformidade dos objetos não constituiu uma classe, e que "cada peça tem que ser pesada individualmente" (ibid.)

O que Lacan quer introduzir com essa forma da suspeita é a noção absoluta da diferença, referência do individuo com todos os demais, é a exigência fundamental da lógica da coleção. Desta forma, não há universal possível, um trabalho coletivo, feito por todos em conjunto, porque o que existe é a questão de cada um, um por um, com a ajuda deste um a mais, portador de uma ligeira diferença na posição.

Um escolhido dentre outros da comunidade analítica, para ocupar não o lugar do mestre, mas sem dúvida da autoridade, nem paternalista ou autoritária. Uma posição aqui entendida 
pela lógica socrática, aquela que sabe que não há saber todo, ou como a posição hegeliana, que devolve o saber ao escravo. Mesmo sabendo que as pessoas fiquem contentes em ter um líder, aquele que conduz, a posição do mais-um, se aproxima da posição de Lacan na Escola, que falava do lugar do analisando e não do mestre.

\begin{abstract}
Não terei a pretensão de reconhecer-me como infalível, mas, como todo mundo, que eu seja no nível da verdade que fala - e não do saber. Eu não me considero o sujeito do saber, fui eu que inventei isso, e para que o psicanalista, o que é mais comum, pare de se crer, quero dizer, idêntico a ele. (LACAN, 1980, p.58).
\end{abstract}

A tarefa do mais-um está centrada no funcionamento, na vida do cartel. Ele deve "velar sobre os efeitos internos, efeitos de grupo que vimos no capitulo um, e provocar a elaboração, colocar a céu-aberto os seus resultados" Essa é uma posição bastante diferenciada que a psicanálise lacaniana quer introduzir, não da prática de pessoa, indivíduo que falamos no primeiro capítulo, de um papel que tenha que desempenhar no grupo, mas de uma posição em relação ao discurso analítico.

É preciso que se inove, disse - salvo não sozinho. Vejo isso assim: que cada um ponha algo seu. Vamos. Reúnam-se vários, grudem-se o tempo necessário para fazer alguma coisa, e depois dissolvam-se para fazer outra coisa. (1975, ibid. p.54).

As pessoas que se engajam neste dispositivo o fazem sabendo da sua dupla finalidade o término e a escrita de um texto ao final. Ele é composto de pessoas, indivíduos ou, se preferirem, seres falantes, que trabalham em torno de um tema geral, mas, cada um, com uma questão particular, que os levarão a produzir um texto escrito, cada um, inclusive o mais-um, ao final do tempo de existência do cartel. Essa criação, que é o produto é de cada um, e não do coletivo, não é sem consequiências. A palavra produzida em um texto, não é uma palavra vazia, mas uma palavra significada, mostra a nossa autoria, uma tentativa de circunscrever o real, um fato de difícil acontecimento.

Por esse motivo, a escrita para a psicanálise tem algumas particularidades que não podem ser reduzidos à produção de uma folha datilografada, devido à própria estrutura da linguagem, com a ambigüidade da palavra e a sua intrínseca possibilidade de deslizamento de sentido. O produto próprio de cada um pode ser entendido como algo que surge desta falha que se chama sujeito, no ato de ligar um significante a um outro significante, se conta como um e nada mais, pois "só existe criação, cada vez que avançamos uma palavra, fazemos surgir do nada, ex-nihilo, uma coisa”. (ibid. p.191).

O contrato de trabalho é claro: na clinica psicanalítica e no cartel. Ele define um trabalhar fundamentado na lógica do inconsciente estruturado como uma linguagem. $\mathrm{Na}$ primeira, nas análises, pede-se que fale, não importa o quê, pede-se que se associe livremente. 
No segundo, no cartel, pede-se que se escreva um texto, que se diga o ponto em que se encontra na sua pesquisa, ou fale dos impasses que atravessou no percurso, pede-se que escreva algo mesmo que não passe de balbucios. Nesta lógica, não podemos pedir uma enunciação coletiva do sujeito, ou um trabalho em grupo, mas apenas um "produto próprio de cada um". 
UMA EXPERIENCIA COM CARTEL E ADOLESCENTES NO CAMPO EDUCACIONAL 


\title{
CAPÍTULO 3. Uma experiência com cartel e adolescentes no campo educacional.
}

\author{
Gostaria que a prática de cartéis que imaginei se instaurasse de maneira \\ mais estável na Escola. (LACAN, IV Jornadas dos Cartéis - Sessão \\ de Encerramento 1975)
}

Por que será que, apesar do desejo do fundador, ainda verificamos, na experiência e nos documentos consultados, que a prática dos cartéis ainda não se deu de forma estável na Escola? Verificamos que ela acontece em alguns lugares mais do que em outros, em determinados momentos da formação do analista mais do que noutros. Seria isso decorrente de alguma particularidade de cada um dos locais, onde a Escola de Lacan se inscreve? Ou existe algo disfuncional com o dispositivo?

Certamente não poderemos responder adequadamente a essas questões que se colocam no percurso desse estudo, porque elas implicariam numa avaliação do dispositivo nas instâncias onde estão sendo questionadas, portanto, dentro do conjunto de instituições que fazem parte do significante Campo Lacaniano. Contudo, para não impossibilitar o nosso estudo, decidimos trabalhar o próprio dispositivo, seu funcionamento e vicissitudes, dentro do campo que concerne esse trabalho, o Campo Educacional.

O local que encontramos para realização desse estudo tratava-se de uma instituição para-escolar, um centro juvenil na zona oeste da cidade de São Paulo, que acolhe adolescentes de 11 a 14 anos, em situação de risco e vulnerabilidade social, no turno oposto ao que freqüentam a escola regular. Isso nos obrigou a enfrentar mais alguns desafios: instaurar uma transferência de trabalho com jovens alguns ainda não totalmente alfabetizados, utilizando um dispositivo que tem por finalidade a dissolução em um tempo específico e a escrita de um texto ao final do processo.

Para não paralisarmos a parte prática, que esse estudo desde o inicio contemplava, adotamos algumas estratégias. Realizamos em um primeiro momento algumas reuniões com os jovens explicando o funcionamento dos cartéis: a propriedade de dissolução inerente à sua estrutura; o tema que teriam que escolher, caso desejassem participar; as questões individuais, que deveriam construir; o artigo que deveriam escrever e, por fim a função do mais-um.

Contrariamente à nossa expectativa, muitos jovens se interessaram em participar da proposta, mesmo sabendo da condição de ter que escrever um texto e apresentá-lo em uma jornada que seria criada para esse fim. Muitos sem saber escrever, ou mesmo escrevendo com muita dificuldade, desejaram participar. Eles se organizaram por tema e, na maioria dos cartéis, exceto por um, nos escolheram como mais-um. 
Apesar da receptividade a nossa proposta, as pessoas naquele momento não tinham uma demanda espontânea para participarem de um cartel ou uma questão de estudo para dar partida ao conjunto. Assim, continuamos, nesse primeiro tempo, trabalhando tentando implicá-los com uma questão, pois, sabemos que é a oferta que gera a demanda. ${ }^{14}$

Assim, nesse primeiro momento, conseguimos retirar deles alguns temas de interesse, mas ainda muito poucas e questões. Como muitos interesses se repetiam, e nós queríamos introduzir a lógica borromeana dos cartéis, recorremos a uma estratégia técnica. Pedimos para que eles escolhessem uma das cinco formas geométricas distintas dispostas em um cartão e que justificassem os motivos das escolhas.

Com esse procedimento, os jovens puderam constatar que, mesmo os que haviam selecionado a mesma forma, ou o mesmo tema, os escolheram por motivos diferentes. Acreditávamos com isso estar inserindo traços da diferença, apesar da semelhança, e, que era uma estratégia adequada para explicar o funcionamento do cartel: todos implicados com um tema, mas cada um com a sua questão. Formaram-se seis cartéis sobre: Curiosidades, Natureza, Vida, História, Rebeldes, Arte e Amor.

Alguns poucos funcionavam "bem”, outros não. Até o momento nada surpreendente já que estamos na lógica do "não - todo" e isso é perfeitamente esperável. No cartel sobre a Natureza, cada membro tinha a sua questão. Eles consultavam livros, jornais, internet e não colocavam o mais-um no lugar de quem ensina, mesmo porque ela pouco sabia sobre os assuntos estudados. Todos liam em suas casas, algumas coisas estavam sendo descobertas, as discussões aconteciam, mesmo com muito riso e brincadeiras por parte de duas integrantes durante as reuniões. ${ }^{15}$

Os demais cartéis funcionavam "muito mal". Muitos não tinham uma questão que de fato pudesse fazer deslizar a cadeia significante e o tema geral não despertava interesse ao mais-um. No cartel sobre Rebeldes, uma novela transmitida em um canal fechado de televisão, as meninas traziam fotos, álbuns ou revistas. O mais-um tentava motivar a discussão com os motivos das identificações a artistas, para a palavra rebeldia, mas isso não

\footnotetext{
${ }^{14}$ Estratégias semelhantes, às vezes são introduzidas em algumas instituições psicanalíticas para que as pessoas que se aproximam delas possam saber do que se trata o cartel e que formas de enlaçamento podem fazer com os colegas, pois, uma das hipóteses presentes nesse campo é que a demanda para formações de cartéis é pequena pelo desconhecimento do dispositivo.

${ }^{15}$ Dois integrantes deste cartel, os mais interessados e produtivos, participaram de outro o cartel sobre Música, que consideramos o mais "bem sucedido", no segundo movimento. As duas garotas, que participavam menos e brincavam mais, saíram. E o novo cartel formado foi composto pela única jovem que havia sido nomeada maisum e mais outra pessoa bastante responsável e centrada.
} 
caminhava muito. Elas não tinham o que dizer. Uma pessoa saiu do Centro Juvenil e o enlaçamento deste cartel se desfez.

No cartel sobre artes, um queria saber como se desenhava, outro como era a culinária de outros países e outra pessoa queria saber como fazia para se tornar cantora. Durante as reuniões, não traziam contribuições, faziam silêncio, demonstravam estar desmotivados e desvinculados. Sem espaço adequado para reunião, deitavam-se no chão, não liam, nem traziam contribuições efetivas para o grupo, não participavam das discussões. Em outro grupo, sobre curiosidades, os integrantes queriam saber "tudo" ou "nada" tinham posturas semelhantes e na maioria das vezes brigavam entre si, como se estivessem encenando para o mais-um.

Intrigava-nos nesse ponto, o que poderia estar acontecendo com esses cartéis onde nada efetivamente acontecia que se relacionasse ao trabalho. Eles não eram colaboradores, "não mostravam uma atividade mental dirigida para a solução de problemas", "não utilizavam uma abordagem racional" tal como a definição de grupo de trabalho dada por Bion. O que seria isso? Um problema na demanda? Ou no grupo?

No nosso estudo vimos que um grupo de trabalho pode não acontecer, mesmo quando ele é composto por pessoas adultas. Entretanto, precisávamos analisar, nesse ponto do percurso, se esse seria um problema de cartéis realizados com adolescentes. Com esse intuito, recorremos a alguns estudos relacionados à adolescência, mas, tal como aconteceu no estudo que realizamos sobre grupos, encontramos um excesso de psicologização do adolescente.

Muitos estudos sublinhavam uma preocupação pedagógica e davam muito pouco espaço a causa freudiana. Das leituras realizadas, destacamos o trabalho realizado por Alberti (1999) que aborda a adolescência pelas insígnias introduzidas por Lacan, o simbólico, o imaginário e o real, que foram abordadas no capítulo um, e que são a nossa proposta de leitura.

Ela aponta que, durante muitos anos, a psicanálise entendia a adolescência como um período de crise no individuo. Uma crise que precisava ser apaziguada através de uma intervenção que "fortificasse o ego do adolescente". Acreditava-se que o adolescente era alguém incapaz de enfrentar as invasões do $i d$ e o tratamento devia consistir em apaziguar os conflitos e favorecer, com o ego mais fortificado, a entrada no mundo adulto.

Essa abordagem criou toda sorte de terapias com a ilusão de que é possível "calar o inimigo", as forças advindas do $i d$, facilitando a entrada do adolescente no mundo adulto de forma harmônica e produtiva. A psicanálise lacaniana aqui também vai à outra direção. Nessa abordagem, não é preciso fortalecer o ego. Ao contrário, o problema do neurótico é ter um 
ego forte demais, que ao invés de encarar o real da sua incompletude, acredita poder evitá-lo com a criação de perigos externos. (ibid. p.96)

Freud em 1926, dizia que o neurótico está completamente impossibilitado de reagir a esses perigos, que por ventura possam atravessar o seu caminho, por que estes vêm do próprio sujeito, mais precisamente do isso. Para evitar a angustia o ego, antecipa imaginariamente o perigo, desencadeando um processo de defesa, que normalmente seria utilizados diante de um perigo real. O perigo é imaginário e a defesa se torna inibidora de todo ato do sujeito, tendo como principal ocorrência a depressão.

Não há como o sujeito não sofrer do inconsciente. Ele é divido pelo sofrimento. Estruturalmente ele determinado pela sexualidade, pelo mundo pulsional que diz respeito aa realidade psíquica. Não é só o adolescente que sofre isso. Entretanto, em razão da puberdade ele está em turbilhão. "quando não há ritos que lhe imponham sólidos limites para o reforço da repressão, o adolescente pode ter seu sono interrompido por muito tempo, promovendo lampejos de lucidez" (ibid.97)

Nessas condições, em que são necessários limites sólidos, seria o cartel uma formação grupal difícil para o adolescente participar, já que seu funcionamento não pressupõe hierarquia ou posições delimitadas? Mais do que obter respostas conclusivas interessa-nos seguir perguntando.

Para a psicanálise o sujeito não envelhece, ele é um efeito do discurso, a direção do tratamento não aponta para o fortalecimento. Ao contrário, ela aponta para a destituição subjetiva, ou seja, para a queda o ego, senhor de tudo. É uma posição ética, nada retórica, que a psicanálise introduz na civilização da impossibilidade de todos nós, adolescentes ou não, escaparmos do mal-estar e da realidade não ser enganosa.

A clinica com adolescentes que a psicanálise lacaniana introduz, com Freud, não é nem para fortificar ego, nem para adormecer o sujeito, mas para "implicá-lo nessa crise como sujeito; não para reforçar a posição do 'quando casar isso passa', mas antes para que isso não passe, mesmo porque, por mais que se reforce o ego, isso de fato, não passa". (ibid. p 100).

Ao contrário de permitir a constituição da sexualidade adulta como algo harmônico, o primado da genitalidade a introduz no campo da impossível completude, já que a submissão da libido ao significante, por um lado, marginaliza o mundo das pulsões e, por outro, implica uma proibição que divide o campo do gozo: ali onde o sujeito goza, ele faz algo de proibido; ali onde ele se submete a esse primado, não goza. (ibid. p.98)

Se a psicanálise de Freud com Lacan denuncia-se essa incompatibilidade do gozo com a regulação da sexualidade é para marcar que não se pode prometer a felicidade. Se existe 
crise na adolescência é por que a crise é inerente ao humano. Ela existe por que a sexualidade, muito antes de fazer sentido, faz furo no real. A crise nessa etapa da vida, para Freud e Lacan, é do encontro com o sexo, que se faz mais em forma de desencontro, do que uma tendência à harmonização.

É verdade que muitos adolescentes tentam suturar a crise andando em bandos ou formando panelinhas, como vimos no capítulo um. Mas por que precisaríamos esperar os adolescentes "crescerem", ou "saírem da crise" para podermos participar juntos de um cartel e aprendermos alguma coisa dessa experiência, que aproxima cada um do seu desejo, da sua questão e do seu "produto próprio", ao final de um percurso?

Ainda não convencidos que devíamos parar a investigação desse dispositivo, por estar sendo realizado com jovens, resolvemos investigar outras variáveis. Seria o motivo do desinteresse, das atuações nos grupos, a forma com que o cartel foi apresentado na instituição?

Afinal, eles foram "pegos de surpresa", não sabiam do que se tratava e talvez por não quererem "ficar de fora" resolveram participar. Além disso, os cartéis também haviam sido propostos e organizados por aquele que acabou ocupando o lugar do mais-um. Ou seja, em vez de ser convidado pelos quatros reunidos em torno de um tema e velar pelo funcionamento do grupo, o mais-um fez uma oferta que tinha embutida uma demanda: estudar o funcionamento dos cartéis com jovens em idade escolar.

Ora, por se ocupar indefinidamente com as demandas e não verificar o seu desejo, o sujeito neurótico tem a pior dívida consigo mesmo, enganando-se ao afirmar que suas demandas ao Outro correspondem ao seu desejo. Isso é um engodo que o jovem, mais do que qualquer outro, rapidamente percebe.

\footnotetext{
$\mathrm{O}$ adolescente se desespera por entrevê esse engodo. Ele entrevê sua própria perda na trama arquitetada das demandas. E, em razão da neurose, da fortaleza egóica, muitas vezes permanece no engodo. Em outras procuram escapar sem saber como, na ilusão de que, como dizia o poeta Drummond, é mais fácil colonizar a Lua, ir a Marte, do que fazer surgir d'isso o que está velado. (ibid. p.105).
}

Verificando que os jovens já estavam sensibilizados pelo dispositivo fazia-se necessário corrigir a rota da demanda Assim, o mais-um "dissolveu" todos os cartéis. Essa manobra foi uma estratégia fundamental para restaurar a natureza do dispositivo: quatro pessoas se escolhem livremente ao redor de um tema comum e escolhem mais uma pessoa para fazer o dispositivo funcionar. Ela nos faz refletir sobre alguns pontos fundamentas da lógica dos cartéis nas instituições. 
Os cartéis se dissolvem, na maioria das vezes, pela saída de um dos membros em igualdade de posições, amarrados solidariamente, às vezes, pela sugestão do mais-um, não pela sua decisão. A razão está na topologia. Apenas os três aros, o real, o simbólico e o imaginário estão em posição de igualdade e sujeitos à propriedade borromeana.

O mais-um, tal como o Nome-do-Pai, ou o sintoma, só entra depois na partida, não antes. Ele é um quarto nó que está para amarrar os outros três e dar estabilidade ao sistema. Ele entra como função e não com igualdade de posição. Isso mostra que nova oferta do dispositivo precisava ser feita sob novas bases, para que pudéssemos dar prosseguimento a nossa investigação.

Uma carta de agradecimento foi lida para todos na reunião de dis-solução e uma nova oferta do dispositivo foi feita para aqueles que, já sabendo do que se tratava, poderiam fazer novos enlaçamentos se desejassem. Para isso, teriam que fazer uma ficha de declaração do novo cartel, com o nome de cada um dos membros por escrito e cada um com a sua questão individual e escolher e convidar o mais-um.

Restaurávamos com esse procedimento a lógica de declaração de cartéis presentes nas instituições psicanalíticas. Uma forma de implicação na instituição com a sua questão, com o seu desejo. Certamente nesse estudo não trabalhávamos numa instituição dessa ordem. Os jovens lá participam no turno oposto ao da escola de atividades recreativas e culturais que acontecem nas quadras, na biblioteca e brinquedoteca. $\mathrm{O}$ cartel se incluía nesse conjunto como uma oferta possível para os que desejassem.

Sabíamos que fazíamos uma oferta com uma escolha forçada já que não havia doze peças com aparência semelhante, com uma diferença de peso imperceptível, que pudessem ocupar esse lugar. No entanto, agora eles sabiam da função do mais-um e tinham a opção de escolhê-lo ou não. Mais uma vez, torcíamos para que não houvesse muita demanda, mas não foi o que aconteceu.

Entretanto, desta vez, só aceitamos a inclusão nos cartéis que realmente nos interessavam. Tal como os demais membros, o mais-um também precisa entrar com o seu desejo, porque só a partir do seu desejo pode motivar a produção de um saber por parte dos outros membros. Provocar neles um desejo de produzir e por em discussão o que estão pensando.

O dever ético do mais-um seria o de conseguir esse objetivo, essa transferência de trabalho. É possível, e empiricamente freqüente, um cartel dirigir ao mais-um a demanda de "ser ensinado". Talvez esse tipo de pedido seja o mais paralisante para a produção de um desejo de saber. As pessoas que assistem a um ensino ficam geralmente passivas frente a esse saber já pronto, ao que dirigem seu amor, amor ao saber. $\mathrm{O}$ que conseguem repetir frases já feitas, os famosos chavões lacanianos. $\mathrm{O}$ 
mais-um assumiria o dever ético de transformar esse pedido de ensino em uma transferência de trabalho". (JIMENEZ, 1994, p.21).

Vimos no capítulo um que a identificação é, para a psicanálise lacaniana, a identificação ao objeto de desejo do Outro, ou, de outro modo, a falta do Outro. No cartel todos estão enlaçados de modo a que o objeto a, objeto de desejo, fique no centro. Isso promove a identificação dos membros de um cartel: todos, até o mais-um, identificados a um objeto de desejo: o tema central do cartel.

Identificação ao desejo, é muito diferente do amor ao saber, já que esse último está relacionado ao horror de saber sobre a castração do Outro. (ibid.). O amor, diferentemente do desejo, tem uma dimensão imaginária: que é suprir a falta. Ele está relacionado com o engodo do conhecimento, ou seja, da crença que é possível haver uma coincidência entre o pensamento e o objeto, como engodo de achar que pode chegar, a saber, a verdade, desconhecendo que ela tente ao real, ao impossível.

Se os jovens, em um primeiro momento, se aproximaram dos cartéis por amor ao saber, para "ficar junto" ou "para aprender qualquer coisa". No segundo momento, houve um reposicionamento. Nos cartéis recém formados, agora tinha uma questão e se organizavam para dar conta dela, fazendo com que a grande maioria dos jovens atuasse de forma "menos indisciplinada": diminuíram a quantidade de falas vazias e atuações.

Muitos se organizavam primeiro pelas identificações imaginárias com os colegas e depois passavam para a escolha de um tema. Um grupo pensou em estudar a pobreza, sexo, fofoca e mistérios, mas resolveram que iriam estudar sobre a dança. Ficaram animadas quando chegaram a essa possibilidade e convidaram o mais-um. Nenhuma questão mais específica conseguiu ser delimitada. Todas menos uma, que queria estudar valsa, tinham interesse no hip-hop e o mais-um que desejava investigar o processo de criação de forma geral e de uma coreografia, de modo específico.

A indeterminação de uma questão também é muito recorrente nas configurações de cartéis nas instituições psicanalíticas. Muitos sabem o tema que desejam examinar, como, por exemplo, as psicoses, a direção do tratamento ou o final de análise. Entretanto, nem todos os membros partem de uma questão especifica no inicio do cartel. Mas, como ele precisa ser declarado à Escola através das Fichas, muitos precipitam uma questão, que nem sempre permanece a mesma até o final do percurso. 
Mas o importante na formulação da questão é a provocação ao trabalho, o impulso ao ato que levará a escrita de um produto próprio. Lacan, em seu seminário sobre o ato analítico nos chama atenção sobre o ato e o movimento:

[...] se eu ando de um lado para o outro, isso não constitui um ato, mas se me coloco fora da lei, isso sim é um ato. (...) eu teria podido, muito bem, calar-me. Eu teria podido reservar só para mim a satisfação de jogar com o inconsciente sem explicar a brincadeira, sem dizer que é pelo truque dos efeitos do significante que se trabalha. Em suma, se não me tivessem realmente forçado, eu não teria jamais ensinado. (DURET, 1994, p.170).

Parece-nos que o que há de mais singular e interessante na proposta dos cartéis é a colocação em ato de um tipo de enlaçamento que promove um empuxo ao trabalho. As pessoas se reúnem e sabem que terão que produzir um texto ao final. Entretanto a experiência, nas instituições psicanalíticas, mostra que isso nem sempre acontece. Muitos cartéis trabalham bem os dois anos estipulados, quando chega o momento de concluir, dois ou três, conseguem escrever um texto que será apresentado em jornadas ou publicado em revistas, e os demais muitas vezes, por motivos diversos não o fazem.

Ora, vimos com Alberti que o problema do neurótico é ter um ego forte demais, que ao invés de encarar o real da sua incompletude, acredita poder evitá-lo com a criação de perigos externos, que são imaginários inibindo de todo ato do sujeito. Não surpreende que, em tantos cartéis, haja inibição da escrita. A produção de um escrito implica em perda. Supomos que o cartelizante, mesmo sabendo do que se trata, entra na tarefa com a ilusão de fazer-o-todo com os demais membros do cartel, mas, ao final do jogo, algo precisa cair. O grupo precisa se dissolver, para fazer uma outra coisa e o texto é aquilo que resta desse percurso, o objeto que cai.

Sabemos que a universidade cria estratégias bastante eficazes para lidar com essa inibição: avaliações, orientação, banca de pré-qualificação, qualificação. Sabemos que Lacan esteve na universidade e escreveu uma tese. Seria a definição de um tempo: máximo de dois anos estipulados para o trabalho em cartel, uma aproximação que ele tentava fazer com os procedimentos universitários? Se encontrarmos uma reposta afirmativa para essa questão, diríamos que ele "não importou" todas as exigências necessárias: prazo improrrogável para entrega do produto e uma máquina bem estruturada e qualificada para fazer a "coisa" andar.

Entretanto, ele não poderia criar os mesmos procedimentos em sua Escola, pois isso seria ir contra o que ele pensava em montar, um lugar anti-totalitarismos e contra a hierarquia. Entretanto, vemos que com ou sem hierarquia, ainda assim, algo falha. Os alunos de graduação muitas vezes não trabalham o suficiente, muitos fazem apenas "o que o mestre 
manda"; os de pós-graduação, nem sempre conseguem dizer aquilo que pensam quando escrevem e os cartelizantes dificilmente conseguem escrever um "produto próprio", sem repetição de frases ou clichês.

Apesar disso, é preciso trabalhar "para produzir”, caso contrário, restará a inércia, a repetição de conhecimentos estabelecidos, sem produção de ensinamentos. É o que ensina Platão no diálogo de Fedra, sobre a origem da escrita.

Thot, deusa da Escrita e do Pharmakon, palavra pivô de duplo sentido, indicando tanto remédio quanto veneno, vai encontra o faraó para lhe apresentar a sua descoberta: 'Eis, ó rei! Um conhecimento que terá por feito tornar os egípcios mais instruídos, mais capazes de rememorar. Aí eles encontrarão o seu remédio para a memória e para a instrução'.

O rei Thamous, que não tem necessidade de escrever, pois sua palavra basta, responde: 'Este conhecimento terá por resultado tornar a alma dos homens esquecidas, pois eles cessarão de exercer sua memória, confiantes no escrito. É de fora, graças a impressões estranhas, e não de dentro e graças a eles mesmos, que rememorarão as coisas. Não é, portanto, para a memória, mas para rememoração de que você descobriu um remédio. Quanto à instrução, esta é a aparência (doxa) que dá aos teus alunos, e não a verdade (aletheia). Efetivamente, na tua área, eles vomitarão conhecimentos sem terem recebido ensinamento. Eles parecerão bons para julgarem mil coisas e serão insuportáveis porque terão a aparência de homens instruídos, em vez de serem homens instruídos. (MÉNARD ,p.102).

Um trabalho em cartel poderá levar a alguns escritos, mas nem sempre isso acontece, nem é certo que esses resultados do trabalho chamem uma leitura, "muitos repousarão no cemitério das bibliotecas". (MAHJOUB-TROBAS, 1998, p. 122). As resistências são inúmeras. Muitos se sentem incapazes de irem além da repetição pura de conhecimentos, como advertiu o rei faraó ao Thot, deus da escrita. Poucos conseguem contribuir com algo de seu. Lembremos a estrutura de linguagem. O discurso corrente gira em círculos, o que indica não haver relação sexual, o ato analítico, ou a demanda de escrita em um cartel,; faz quebrar esse giro em círculo, faz com que de alguma forma algo se escreva, faz borda ao real, que se define como impossível. Isso não é sem consequiências, pode favorecer a criação, mudança de posição e, sabemos, isso gera resistências.

Na prova do escrito, o dito não pesa muito; dele se exclui o blábláblá, a fala vazia, onde se engolfa a significação. E quanto a besteira, sublinhemos contudo que não há besteira ideal, só fica para nós a aposta de um além do enunciado que alcançaria esse significante mestre, significante pelo qual os outros se ordenam. Acrescentemos que essa aposta incide igualmente sobre o eventual encontro de um significante novo, outra definição de S1, ou seja, abertura para o real. (ibid. p. 122).

Enfim, se para todos, do escrito, sempre resta sobre o papel a insatisfação do objeto sempre perdido, deveríamos então aboli-lo como exigência para os cartéis? Tendemos a dizer que não, principalmente porque sempre existiram na história cartéis para organizar bibliotecas, eventos, programas de ensino. Seriam essas distorções da proposta? Não podemos 
dizer que não, já que os textos nos anos 80, quando da reformulação dos cartéis, são claros quanto à produção de um produto próprio; ainda assim, gostaríamos de continuar a reflexão.

Sabemos que existe uma grande diferença entre preencher uma folha de papel com fala vazia e blábláblá e a escrita para a psicanálise, que é a manifestação em texto da própria estrutura da linguagem, na sua possibilidade de deslocamento de sentido. No entanto, acreditamos que a oferta de se escrever um texto, um produto próprio, é dar a possibilidade para qualquer um de remeter um significante a outro e quem sabe, numa contingência, algo que não cessava de não se escrever, por ser impossível, passe a se escrever, e algo novo possa emergir.

Com essa aposta de que algo podia emergir desses cartéis, não desistimos de trabalhar com esses jovens que tinham dificuldades reais com a escrita. Voltemos à experiência realizada para ver o que ela nos ensina, pois, como diz Alberti no seu trabalho "esse sujeito adolescente tem bem mais para ensinar ao psicanalista, do que podem supor os autores de vinte anos atrás”. (opus cit. p. 11).

Como estratégia para levá-las à escrita do produto próprio, o mais-um solicitou que escrevessem um esboço do que poderia constar nesse texto. Durante o brainstorming, pensaram em falar da origem, das roupas, das danças e também em que medida o saber disso havia modificado alguma coisa na vida delas, o que poderiam criar dali. Pensamos que também seria interessante falar como havia sido participar do cartel. Escrevemos essas questões e uma delas pediu para ficar com o papel que continha as anotações.

Durante as reuniões, as duas mais motivadas e decididas a apresentarem um texto na Jornada, tentavam convencer as colegas de participarem mais e não saírem do grupo, que nesse caso, seria forçado á dissolução. Elas levavam vídeos, pesquisavam na Internet e participavam bastante das reuniões. Por vezes diziam: "queria ter mais horas com a Silvana" ou, da despedida, de forma motivada, afirmavam: "semana que vem a gente conversa mais".

As outras três participantes eram bem menos implicadas. Notava-se que tinham muito mais dificuldades escolares que as duas que apresentaram textos na Jornada. Elas se dispersavam facilmente nas discussões, procuravam fazer outras coisas, como olhar livros com histórias infantis ou brincar com o celular.

Mesmo sem a obrigatoriedade da apresentação pública, todas foram estimuladas a escreverem um esboço e um trabalho final, como é o objetivo do cartel. Elas fizeram isso minimamente. No dia do esboço, passaram bastante tempo escrevendo e decorando os seus nomes com marcadores de texto e, ao final, compuseram apenas fragmentos. Uma delas, a interessada em valsa, escreveu: "Eu achei que nesse projeto com a Silvana foi muito legal e 
divertido, porque aprendemos mais sobre o hip-hop, do que já sabíamos" [grifos nossos]. Perguntada sobre a possibilidade de dizer mais, responde: "Depois continuo. Não consigo tirar mais nada da minha cabeça".

Outro membro do grupo, que durante as reuniões causava bastante conflito e pronunciava palavras inadequadas quando falava com os outros, disse: "Eu achei muito legal. Foi muito boa as aula". Quando perguntada sobre o que tinha achado bom, respondeu para o mais-um: "Nós aprendemo bastante coisas, assuntos do hip-hop, como por exemplo". O mais-um insistindo mais um pouco em saber $o$ quê ela havia aprendido, obteve de resposta: "o que você ensinou"; "e o que foi?", tentamos mais uma vez. Virando-se para a outra colega que participava mais das reuniões, perguntou: "C. o que foi que a Silvana ensinou para a gente?".

A única participante desse cartel que desde o início "confessou" não saber escrever nos utilizou como "escriba" para dizer as suas idéias. Ela falava de forma lenta, sempre desviando o olhar para outro lado da sala ou brincando com outros objetos na mesa. O seu texto ditado foi: "Aprendi que o hip-hop é legal, que eles dançam de ponta-cabeça, rodam com o braço e eles mesmos inventam. Eu gosto de assistir o hip-hip porque eles usam uma roupa da hora bem interessante. Também nós aprende com eles algumas dança”. Nesse dia, combinamos que todas levariam esse rascunho para casa e tentariam escrever algo mais.

No dia da apresentação para o grupo, uma semana antes da apresentação final na Jornada, apenas A. compareceu à reunião. Ela entrou na sala com um papel bem enrolado na mão dizendo: "Esse é o trabalho da C.. As outras não quiseram vir". O trabalho tinha uma capa bonita com cores. O texto havia sido escrito com limitação, com erros ortográficos, porém, com capricho. Lemos e verificamos que correspondia a respostas a perguntas previamente formuladas.

O mais-um acolheu o trabalho da C. e aproveitou para perguntar a A. sobre o trabalho dela. Ela justificou-se alegando falta de tempo, pois, tinha entrado em um curso de computação e de inglês. Certamente uma resposta que apontava para a resistência. Todavia, nos intrigava que muitos jovens utilizavam esses e outros cursos como justificativa para sua falta de tempo. Será que estávamos diante de um excesso de conhecimentos superficiais sobre muitos assuntos, impedindo que o sujeito parasse de girar em círculos ao redor do furo e se confrontasse com sua própria falta?

Advertido dessa estratégia recorrente utilizada pelos neuróticos, o mais-um mostrou para ela uma cópia do rascunho que ela havia feito na semana anterior e lembrando-lhe que sempre dizia que queria ir mais longe na vida. "Então, essa é uma boa oportunidade de ir um 
pouco mais longe naquilo que já fez, não?”, argumentou. Intervenção que provocou uma reação e mudança de posição. A animou-se a reescrevê-lo ali mesmo naquela reunião.

No dia da Jornada, duas integrantes produziram "um ensaio" para o evento. ${ }^{16}$ Os demais membros do cartel não escreveram nada, mas estavam lá e ajudaram na arrumação da sala. Uma delas, voluntariamente, colocou o título da atividade na lousa e as duas outras pediram para ficarem responsáveis pela colocação de água na mesa dos participantes. Dois outros cartéis tiveram um desfecho semelhante: o sobre "sexualidade" e o sobre o "amor", ou seja, nem todos produziram um texto no final, mas todas estavam na Jornada interessadas e colaboradoras.

Percebemos nesse fragmento a dificuldade que elas tinham de elaborarem um saber daquilo que as interessava, mesmo com a tentativa do mais-um de que fossem mais além daquilo que diziam, mesmo apesar de toda resistência. O mais-um não era mestre, nem analista, mas um agente provocador de elaboração, ele inicia a provocação, mas esta não lhe é exclusiva. Algumas integrantes no grupo estimulavam a produção, "tentavam convencer as colegas de participarem mais e não saírem do grupo, que nesse caso, seria forçado á dissolução".

Sabemos que o processo da escrita implica numa reflexão mínima, nem que seja para escolher que significantes serão utilizados da trama discursiva. A escrita pode favorecer a ver coisas de forma mais clara, para que se ultrapassem as simples constatações. Por isso, estimula-se a redação para os alunos em idade escolar e pede-se com freqüência para que os professores registrem seu trabalho por escrito, nos cursos de formação permanente, porque se acredita que isso os levará a construir uma prática de reflexão.

$\mathrm{O}$ ato de refletir por escrito possibilita a criação de um espaço para que a reflexão sobre a prática ultrapasse a simples constatação. Escrever sobre alguma coisa faz com que se construa uma experiência de reflexão organizada, produzindo, para nós mesmos, um conhecimento mais aprofundado sobre a prática, sobre as nossas crenças, sobre o que sabemos e o que não sabemos. (WEIZ, 2000, p. 129).

Entretanto, não é nada simples, como vemos no depoimento deste professor:

Quando fui realizar a tarefa me surpreendi com o grau de dificuldade - o que me parecia simples era extremamente complexo. Primeiramente eu teria de criar um encaminhamento para conseguir que meus alunos aprendessem determinados conteúdos. E ainda teria de justificar a coerência entre a concepção de ensino e de aprendizagem construtivista, o encaminhamento, os conteúdos e os objetivos. (opus cit p.129).

\footnotetext{
${ }^{16}$ Estes e todos os demais textos estão no anexo para apreciação.
} 
Dificuldade que encontra eco no depoimento de alguns escritores:

Não sei fazer outra coisa... Então, primeiro, eu escrevo porque bem ou mal, é a única coisa que sei fazer; segundo, porque é um ofício que, sendo difícil, duro, por vezes dramático mesmo, é um ofício que dá também muita alegria, uma certa satisfação por ter feito alguma coisa. (JORGE AMADO, 1991, p.100).

No cartel, a escrita de um texto, faz parte do dispositivo. Os que neles se engajam o fazem sabendo desta finalidade. Intrigou-nos que mesmo sabendo disso, e impossibilitados de escrever, por não saberem, muitos quiseram participar da atividade, mas não nos surpreendeu que nem todos tenham conseguido. Apostávamos que algo podia emergir desses cartéis e estávamos trabalhando com a lógica do "nem-todos", mas alguns "talvez”, isso, por si só, já poderia nos ensinar alguma coisa sobre essa lógica singular do trabalho em grupo.

Neste ponto precisávamos olhar para a produção deles, não com o nosso olhar intelectualizado ou de psicanalistas, julgando a produção pelos nossos parâmetros ou pela nossa linguagem acadêmica. Aqui também adotamos a mesma postura diante do escrito de um autor. Olhar para ele e ver o que podem nos ensinar. Destacamos algumas passagens para nossa reflexão.

Verificamos que muitas vezes não foi possível extrair algo inédito, em oposição ao saber constituído em todo cartel. Muitos trabalhos estavam cheios clichês tais como: "a fé não tem fronteiras" ou cópias de textos "os jardins suspensos da babilônia foram construídos pelo rei Nabucodonosor no século VI a.C. (...)" sem argumentação ao longo do texto sobre as citações, ou seja, sem autoria.

Não podemos dizer também que esta seja uma exclusividade dos cartéis desse estudo. Verificamos isso nos cartéis das instituições psicanalíticas. A criação de algo novo, ou a elaboração de algo em cima do já estabelecido, não é nada fácil. Caberia verificar como se isso se dá em outros lugares onde os cartéis se inscrevem. Mais uma abertura para novas possibilidades de estudo.

O que testemunhamos nos Saraus de Cartéis é que, em muitos grupos, há uma exigência inicial na escolha de alguém que acumule conhecimentos para exercer a função do mais-um. O que passa a circular, então, é o discurso universitário, onde é o saber que faz agir o objeto, produzindo um sujeito impotente.

Evidentemente todos esses discursos comparecem nos grupos, porém é pela presença da função do mais-um, e torno a repetir, apontando para a produção e para o impossível, que o discurso do analista, adormecido por vezes, emerge entre um discurso e outro, provando que o desejo persiste.

Penso agora na ética da psicanálise, onde somente a insistência no acesso ao impossível da Coisa possibilitaria a criação, e aí descolados de modelos e de saberes ordenados estaríamos sujeitos ao desejo. (PAZ, 1998, p.181-2). 
Nessa experiência que tivemos com esses cartéis na instituição para-escolar, tivemos alguns exemplos de abertura, provando que o "desejo persiste", em alguns trabalhos. O novo que se apresentou, talvez não para nós leitores, mas para alguns envolvidos no processo, tal como verificamos no fragmento destacado:

\begin{abstract}
Isso nos interessou muito e aprendemos mais do que o esperado (...) uma coisa que eu não sabia: o significado do número 7 , que significa vida". Também uma outra pessoa que inicia seu texto dizendo: "tirei todas as minhas dúvidas com a Silvana e com as minhas amigas, pois sem elas esse cartel não estaria aqui. Agora eu vou contar para vocês um pouco do que aprendi, estão preparados? Então vamos lá! Eu descobri (...) também percebi que não são só sete maravilhas, tem muito mais... (anexo)
\end{abstract}

É interessante a percepção dessa jovem que "não estaria lá", na Jornada apresentando seu trabalho, "sem as amigas" e "o mais-um” De fato, esse pequeno grupo chamado cartel só existe com a presença de todos esses elementos, enlaçados pelo desejo de produzir e saber algo mais.

Também destacamos do fragmento que ela pudesse se dar conta que "tem muito mais". Isso nos aponta para as aberturas que existem em cada investigação, novos campos de estudos que se abrem, já que o saber é não- todo.

Essa jovem, sem saber, nos ensina sobre impossível: "essas são as sete maravilhas do mundo; as outras que não discutimos, ainda não tenho muito o que dizer". Entretanto, o problema do neurótico é que ele quer dar sentido a tudo. Assim, ela nos promete: "só vocês visitando vocês iam descobrir realmente tudo".

O mais-um, o educador ou o professor analiticamente orientados, sabem que não há possibilidade de dizer tudo e que a verdade é impossível pela própria condição da linguagem.

Orientados pela psicanálise, eles não precisarão dizer para essa jovem que ela está equivocada de pensar assim, que, infelizmente, mesmo visitando as sete maravilhas do mundo, não se descobre tudo. Ele não precisará demovê-la dessa idéia, mas pode convocá-la a dizer mais, porque sabe que toda possibilidade de tentar dizer mais um pouco, que promove aberturas no discurso e mudanças na estrutura.

Ao dar poder de fala ao outro, não se tira nada de si. Essa é a condição de liberdade que se atinge quando se sai da relação dual alienante, tal qual a do senhor - escravo, do professor-aluno, etc, relações onde muitas vezes prevalece o desejo de reconhecimento e o reconhecimento do desejo.

De um lugar analiticamente orientado, não há mais necessidade de lutar contra os outros pelo reconhecimento ou pela verdade absoluta, basta ter uma aliança com o desejo de saber, que vimos não obtura a falta constitutiva presente para todos. 
Através da palavra de Sennet, falando da fenomenologia do espírito, vimos que nos dois últimos estágios para atingir a liberdade, o senhor perde seu poder sobre o seu escravo, não porque o escravo tome seu poder ou o derrube, mas porque ele se tornou uma pessoa diferente, aprendeu a lidar de uma maneira não competitiva com o senhor e isso obriga este último a modular o seu próprio comportamento.

Pensamos que aí reside um ponto importante da configuração dos cartéis. O mais-um não entra, ou melhor, não deveria entrar, com o papel de suposto saber ou suposto liderar. Em posição de igualdade com os demais membros, ele entra dividido com uma questão.

Sua postura investigativa, tal como deve ser também a postura dos demais, estabelece, ou devia estabelecer, uma relação não competitiva com o outro. Se aposta nessa horizontalidade, e na função do mais-um, presença simbólica, nunca imaginária, que aponta para uma direção diferente do fascínio existente na especularidade existente na maioria dos grupos.

Essa estratégia facilitaria a produção de cada participante para além das qualidades comuns que unem as pessoas nos grupos, porque estaria sustentada pelo simbólico de um lado e apontando para o real em jogo, do outro. É claro que essa é uma posição difícil de sustentar, tal como é a posição analítica.

Talvez por isso alguns cartéis não consigam ir até o final, eles "não dêem certo". Existe um real em jogo difícil de suportar para muitos. Mas, se alguns conseguem fazer a travessia e chegam até o final, algo pode surgir. Vejamos abaixo a transcrição, sem correção, de uma das produções surgidas em um dos grupos e apresentada na Jornada de Cartéis.

\section{Muitas personalidades sobre muitos ritmos}

Todas as pessoas tem uma personalidade diferente da outra, uma forma de descobrir personalidades, é pela música. A música tem diversos ritmo como o samba, eletrônica, rep, hip hop, etc...

Também existem músicas romântica, calma. Agitada, triste e alegre. É dessa forma que as pessoas descobrem se são românticas, calmas, agitada, triste ou alegre.

Eu aprendi que a música é feita por notas ou ritmos. 
O cartel me ajudou muito como, e me ensinou a fazer música, até fiz um fank!.

Nenhum ponto negativo, mas muitos pontos positivos como a Silvana ajuda a gente nas dificuldades e nas curiosidades.

A pesquisa que eu fiz foi com muitas pessoas da minha família, das ruas e da minha escola se cada musica combinava com cada pessoa. $O$ ressultado deu:

$50 \%$ das pessoas gostam de música agitada

$30 \%$ das pessoas gostam de música alegre

$25 \%$ das pessoas gostam de música calmas

10\% das pessoas gostam de música românticas

5\% das pessoas gostam de música triste

E esse foi o meu depoimento, aprendir muitas coisas e espero aprender muito mais com a Silvana e com os meus colegas.

OBRIGADO!

Assi: B, p. S.

FUNK DO B.

No meio da boate

Só tinha mulherão

Entrou um traveco e

Subiu no balcão

O traveco me falou

Daqui não saio não

Sai travecão, sai travecão, sai travecão

Daqui não saio não

Naquela boate

Só tinha mulherão

O traveco rebolava e 


\section{Mexia o popozão \\ E ainda insistia}

\section{Daqui não saio não}

Sai travecão, sai travecão, sai travecão

\section{Daqui não saio não}

Vimos com essa produção de final de um cartel que, a partir da questão inicial, podese produzir um texto e inventar algo novo, um funk. No nosso léxico, um "significante novo", se não para nós, talvez para ele. O funk traz o significante "traveco". Na nossa leitura, esse significante pode condensar para esse jovem, tentando se situar entre a partilha dos sexos, o paradigma dos impasses do sujeito diante da confrontação com a impossibilidade de relação e completude entre os sexos, como nos mostra Alberti (opus cit. p. 13).

Essa produção saiu de um dos poucos cartéis que aconteceu tal como um grupo de trabalho, tal como "imaginado" por Lacan ou citado por Bion. O clima entre os participantes foi na maioria dos encontros de colaboração e bom humor, com alguma dose de angústia quando se aproximava a apresentação. Todos se escutavam atentamente. Eles não estabeleceram uma transferência vertical com o mais-um, como alguém que sabe e ensina, mesmo que isso às vezes "escapulisse" nas frases. Percebemos que eles o colocavam de alguém que estava ali para favorecer o trabalho e escrever também.

Todos recorriam aos livros e sites na internet. Uma parte sempre trazia material de pesquisa de casa: revistas, livros ou letras de música para análise. Eles tinham iniciativa e organizavam a reunião dividindo tarefas. Sempre, B. ou L. iniciavam a reunião dizendo propositalmente, tal como nós: “Como foram na semana? Novidades?”. Todos colaboravam e cobravam espontaneamente a frequiência e a participação. Quando um deles propôs revezamento de apresentações, B. discordou e S., que havia trazido um livro sobre canto nesse dia, disse: "Tem que ter boa vontade de ir na biblioteca - eu fui e até paquerei".

No dia que lemos sobre "Como Escrever um Ensaio", vários integrantes desse cartel quiseram sair da reunião com um título. B. disse: “diversas músicas, diversas personalidades"; L arriscou: "de música para música”, mas preferiu esperar para dar o título depois do texto escrito, que seria mais fácil. Para o folder, deram bons palpites e sugestões: "essa capa, com aquele texto", implicaram-se na produção e distribuição. Nesse mesmo dia, fizemos um primeiro rascunho do texto. Acabamos e lemos para todos. Ao final de cada leitura, bateram 
palmas espontaneamente. Todos saíram animados e encorajados para produzirem algo para apresentação interna no grupo e, posteriormente, para a Jornada.

No dia da primeira apresentação, nos receberam calorosamente ainda no pátio. L., animado, disse: “Eu escrevi um texto, só não sei se está bom!”. J. disse que estudou até tarde para concluir o estudo e fazer o seu texto. Todos estavam animados para apresentar. B., havia feito uma música, mas estava com vergonha de cantar. O mais-um estimulou-o, dizendo que se não estivesse bom falariam, para que ele não "fizesse feio" na apresentação. Ele topou e todos acompanharam batucando na mesa, aplaudido-o no final. Quanto todos já haviam apresentado, o mais-um abriu para os comentários.

Para a velha frase que retornava, "aprendi com Silvana”, questionou-se se também não haviam aprendido nos livros, com os colegas e com a experiência de vida deles próprios. Eles concordaram rapidamente. No final, L. que pouco participou nas reuniões, tal como J, afirmou com satisfação: "todo mundo achou que a gente não ia produzir, só porque a gente não trazia material.... [e responde sorrindo] .....a gente se vingou!".

Se parássemos nosso relato neste ponto, podemos pensar que o cartel é um dispositivo interessante e que é bastante adequado à transmissão e a produção de um texto, ou de um significante novo ao final. Entretanto, as coisas não são simples assim. Afinal não estamos nem na lógica do todo, nem no do ideal. Não há harmonia possível, devemos lembrar. Ainda assim cabe investigar, por que a prática de cartéis ainda não se deu de forma estável nas Escolas? Acrescentaríamos a essa pergunta, por que não vemos esse tipo de entusiasmo acima quando falamos do cartel? Tocaremos muito superficialmente em algumas questões, esperando que esse estudo prossiga em outro momento e lugar com novas reflexões.

Escutamos com freqüência nas instituições psicanalíticas que "o cartel é difícil de formar, mas muito fácil dissolver", de um colega da Argentina é que "é muito difícil encontrar um tempo comum para reunir todas as pessoas"; nos textos encontramos que "geralmente os mais jovens fazem cartel, por ser uma forma de aprenderem sobre um determinado tema e de se aproximarem da nova comunidade", na França, os mais "experientes" se engajam em cartéis do passe.

Em verdade é muito mais fácil trabalhar, conhecer e se fazer conhecer em um pequeno grupo. A experiência comprova. Por outro lado, os que já estão a mais tempo na instituição acabam se implicando nela de forma diferenciada. Acabam sendo convidados para conduzir seminários, coordenar redes de estudo, participar de funções administrativas que, somados a sua prática clínica, lhes sobram muito pouco tempo para os cartéis. 
Pela suposição de saber que lhe fazem, muitas vezes entram no dispositivo como maisum e a depender da implicação, e do tempo que tenham disponível, essas pessoas participam mais assiduamente, ou não, das reuniões. Existem depoimentos que afirmam que o dispositivo funciona, mesmo na ausência ocasional do mais-um. Entretanto, a tradição, especialmente na América Latina não é da transmissão em cartel, mas sim da transmissão realizadas em seminários ministrados por analistas experientes e competentes no domínio da teoria.

Vimos no capítulo dois que a invenção dos cartéis tem relação não pode ser dissociada do contexto histórico no qual surgiu. O trabalho com grupos pequenos era a ordem do dia na França, os estudantes se organizavam em grupos de trabalho convidando os colegas a trabalharem juntos, numa base igualitária, uma maneira de fazer oposição ao curso magistral, prática tida como reacionária.

Por outro lado não era essa mesma realidade dos paises latinos. A psicanálise no Brasil não pode ser dissociada do contexto que surgiu e da tradição colonialista do país. Ela foi introduzida no Brasil, na década de 20, no período pós-guerra, como um dos efeitos do modernismo. Nesse momento, foi tomada não como um instrumento terapêutico, mas como um sistema teórico passível de ser aplicado em diversas áreas do saber, como vimos na introdução.

Um segundo período, após a introdução da psicanálise no Brasil, foi caracterizado pela utilização desta como instrumento profilático. Isso estava em conformidade com os ideais eugênicos vigentes na psiquiatria brasileira da época. No final dos anos 70 e 80 vários grupos foram criados no Brasil e em alguns paises da América Latina, com a morte de Lacan, vários desses grupos se organizaram em redes, com adesão a uma doutrina e não no respeito a regras tecnocratas.

Seria a nossa história um fator que dificulta a transmissão por pequenos grupos? Como dissemos, não podemos entrar nessa questão, pois precisaríamos examinar os cartéis dentro das instituições que fomentam a sua prática, e além do mais, "desbaratar esse tema não é coisa de pouca monta" (LEGENDRE, 1983 p.11). No momento, só contamos com fragmentos de experiência com esse dispositivo, que se apontam vantagens também mostram alguns impasses. Voltemos aos nossos jovens e o que eles têm a nos ensinar.

Em alguns grupos, mesmo tendo tido toda a chance de produzirem e ocuparem um lugar diferenciado que não o de submissão, em muitos cartéis, o mais-um era demandado a fornecer as respostas para as questões dos membros. As pessoas atuavam com a suposição básica de dependência, como analisamos no segundo capítulo. Criava-se nesses cartéis 
"estrutura refinada", uma sensação que a situação é familiar e imutável, de um lado, alguém que sabe e de outro, alguém que está em uma condição de dependência, tal como o filho em relação a seus pais, como nos apontou Bion.

Inicialmente poderíamos pensar que esta situação foi favorecida pela idade dos participantes, mas os grupos estudados por Bion mostram, e a nossa experiência também, que podemos verificar essa mesma situação de dependência em cartéis onde todos os integrantes são adultos. Afinal as situações de dependência não estão relacionadas com a idade, mas ocorrem em situações onde o indivíduo é impelido a buscar satisfação em grupo, mas, ao mesmo tempo, estar em grupo estimula e frustra. Vimos com Bion que o fracasso em atender as exigências da tarefa, ou uma atitude questionante do líder, mobiliza os sentimentos regressivos e gera um temor no grupo mais do que em qualquer outra situação.

Lembramos com Lacan que se o neurótico "é egocêntrico e tem horror a qualquer esforço de cooperação, talvez seja porque ele é raramente colocado num meio em que todos os membros acham-se no mesmo pé que ele no que concerne às relações com o seu semelhante". Essa "igualdade" de posições é muito difícil de obter se pensarmos a constituição do sujeito discursivamente ou topologicamente com as insígnias fornecidas por Lacan: o simbólico, o imaginário e o real. Vimos que em poucos agrupamentos, tais como nos bandos ou panelinhas, essa igualdade é apenas imaginariamente conseguida.

Nos cartéis desenvolvidos nessa instituição, o mais-um tinha um nível de "desigualdade" bem maior dos membros se levarmos em conta aspectos da persona, tais como: a idade e o nível educacional, por exemplo. Sabemos que nessas condições estabelecese imaginariamente, e mais facilmente, a relação de dependência. Mas será que em cartéis cuja diferença de idade, ou posição do mais-um em relação aos demais é bem menor, essas suposições não aconteceriam? Nossa experiência mostra que não. Elas acontecem, pela própria estrutura da linguagem, mas cabe continuar refletindo.

Tomemos o exemplo de Lacan que dizia falar da posição do analisando. Não queria ocupar o lugar do mestre, mas sabemos que foi colocado nesse lugar pelos que freqüentavam seu seminário e permanece ocupando o lugar de autoridade até o presente momento. Também tomemos para a análise a função do mais-um, que exatamente por ser função, não pode ocupar um lugar, muito menos o do mestre, daquele que tem as respostas ou o saber que deve ser fornecido. Entretanto, ainda assim, há os que desejam se submeter, que na nossa linguagem esta está ligada às identificações.

No capítulo um, vimos com Lacan e Freud, que a imagem na qual o sujeito se reconheceu é uma ilusão, um Eu Ideal A essa imagem se colam os significantes que vêm do 
Outro, o Ideal do Eu, aquela pessoa que ocupa o lugar de autoridade, é "nisso que se prende às coordenadas inconscientes do Eu e propaga-se a submissão. Monta-se, então, a rede de significantes “não idênticos a si mesmo". Só que a realidade está ai para nos mostrar, e aos nossos cartelizantes, que entre o Eu Ideal, o Ideal do Eu e o Real há uma sucessão infinita de equívocos e distorções. É isso que Lacan quer nos lembrar com o seu retorno a Freud, mas ainda assim, não é bem sucedido.

Ensinar não é o objetivo do cartel, muito menos o objetivo do mais- um, vimos no capítulo dois. A intenção de Lacan ao propor o Cartel como órgão de base da sua Escola, era a transmissão da psicanálise e a sua lógica opunha-se a todo saber constituído, conclusivo, operando de modo a extrair algo inédito, produto da elaboração de cada um dos cartelizantes. Ele precisava inventar algo novo, já que vivia a sua excomunhão da Sociedade de Psicanálise, instituição hierarquizada e fundamentada na transmissão do saber constituído, representado na figura dos analistas didatas. Opunha-se fortemente a hierarquia por gerir sentido, tal como faz a religião.

Tento opor-me a isso para que a psicanálise não seja uma religião, como é sua tendência irresistível desde que se imagina que a interpretação não opera a não ser pelo sentido. Eu ensino que sua mola-mestra está alhures, especificamente no significante como tal (...) É com o turbilhão, com a hélice que eu conto. E, devo dizê-lo, com os recursos de doutrina acumulados em meu ensino. (LACAN, 1975, p.54)

Lacan contava com o turbilhão e dentro dele o instrumento de base da sua Escola, o cartel, uma "máquina anti-totalitarismos". Seu plano de trabalho para a Escola não passava por seminários, conferências, etc. Ele previa três Seções, funcionando como cartéis. Se tivesse que haver seminários ou cursos, deveria ser dado fora da Escola. Esse plano jamais foi realizado. Miller em 1994 (opus.cit. p.15) interroga: por que nunca se realizou o plano de Lacan? Por ser irrealizável? Por não se poder inibir o crescimento de carismas, nem a demanda de carisma? Deve-se realizar este plano? Ou seria um fundamentalismo do cartel? Será preciso modificar alguma coisa da definição do cartel, ou da prática do cartel, para realizar o Plano Lacan? 
CONSIDERAÇOES FINAIS 


\section{CONSIDERAÇÕES FINAIS.}

Enquanto psicanalistas atuando no campo educacional e acadêmico, aprendemos durante a preparação deste projeto, que temos que estar advertidos a respeito de que "não há aplicação possível da psicanálise à pedagogia"(MILLOT , 2001, p.154) como prevenção das neuroses pela educação, pois, o conflito é estrutural. No entanto, constatamos que podemos utilizar a psicanálise nesse campo para interrogar e para aprender, para instaurar um pouco de dúvida lá onde se tem uma ilusão de certezas, já que aprendemos com a filosofia, e com a própria psicanálise, que o saber não se toca a não ser pela ignorância.

Sabíamos que a escolha deste tema nos causaria inúmeros embaraços e impasses devido a sua complexidade, sua interface com o social e a falta de pesquisas psicanalíticas de que trabalhem a análise dos grupos. Não existe $a$ Psicanálise. Ela desde a sua origem e pela sua própria estrutura discursiva, nunca teve uma leitura única das causas das formações psíquicas inconscientes, muito menos uma prática igual para todos. Ela está marcada pela singularidade de cada analista e pelo estilo que os reúne sobre determinadas escolas.

A escola que orienta a nossa prática é a lacaniana, que exige uma leitura não superficial da realidade e privilegia uma leitura de mundo não personalista, utilizando uma prática especulativa tomando como referência a linguagem, que admite idéias não unívocas. Nesse estudo, tivemos o empenho em fazer um descentramento nas nossas convicções, para podermos aprender com colegas de outras orientações psicanalíticas um pouco mais sobre o grupo.

O que movia o nosso estudo era tentar verificar os pontos de aproximação existentes no campo educacional e pedagógico quanto aos meios utilizados para a formação e transmissão: seminários, grupos de pesquisa, grupos de estudo, cartel. Focalizamos nosso estudo no funcionamento dos cartéis, por ser um dispositivo utilizado para a transmissão e para a formação no campo psicanalítico, não por atribuírmos superioridade desse grupo com relação aos demais, mas porque era o funcionamento de grupo com o qual tínhamos mais experiência.

Desse movimento surgiram questões secundárias: o que pode ensinar o cartel, um pequeno grupo inventado por Lacan para transmissão da Psicanálise, aos educadores? O que o

diferencia dos grupos existentes na educação: das formações grupais espontâneas: as panelinhas, os bandos, etc e dos grupos de estudo, grupos operativos, grupos de trabalho e de 
suposição básica? O cartel só pode se inscrever em uma instituição psicanalítica? O cartel poderia acontecer com pessoas mais jovens?

Entramos em campo, e nesse estudo, com o firme propósito de aprendermos mais sobre grupos, o cartel e com jovens participando deles. Esperávamos verificar como se dava o funcionamento e a transmissão nesse dispositivo em comparação a outras formas grupais existentes.

Para dar conta desse intento, adotamos algumas estratégias. $\mathrm{Na}$ primeira parte trabalhamos o conceito de grupo de forma geral e as diferentes formas de abordá-los. Verificamos que existe muita resistência ao tema. Alguns autores acham que é porque o grupo desperta angústia, outros porque representa ameaça da liberdade. Constatamos que o conceito de grupo tal como concebemos hoje, como reunião de pessoas ou como um termo técnico da matemática, é recente e que as principais idéias psicanalíticas sobre esse tema foram elaboradas em um período muito curto.

Vimos que a maioria dos textos de Freud tinha por objeto a cultura, a civilização ou o social. Ele interessava-se em entender como o individuo, através das suas determinações psíquicas, pensa, concebe e fantasia o social. Entretanto, verificamos que muitos estudos estão carregados de "grupalidade", que se preocupa em entender como o grupo pensa ou sente e com uma constituição semelhante ao aparelho psíquico.

Muitas pesquisas relacionadas à educação encontradas nesse campo de interface com a educação tomavam essa perspectiva personalista para leitura da realidade dos grupos e dos indivíduos que o compõem. A grande maioria dos estudos apresentava a noção de círculo e a noção de vínculo como linhas de forças responsáveis pela coesão dos elementos nos grupos. Respeitávamos as abordagens, mas acreditávamos que uma leitura distinta do que acontece nos grupos, podia ser incluída para os que não estão tão familiarizados com outras linhas de força: os efeitos poderosos da linguagem e das formações do inconsciente.

Isso nos obrigou a fazer um recorte difícil de alguns pontos da teoria lacaniana que entende a persona como uma máscara e introduz no seu lugar o conceito de sujeito, que só pode ser do inconsciente, diferenciando-o do individuo. Nesse ponto do estudo, introduzimos a noção de constituição de sujeito tomando como referência os conceitos de real, simbólico e imaginário. Trabalhamos as identificações com essa abordagem e utilizamos os referenciais da Topologia e da Física para fundamentar que os grupos, tal como os sujeitos, não pensam, sofrem, agem, mas estão sujeitos aos efeitos de linguagem e da cultura.

Escrevemos com o firme propósito de contribuir para a prática daqueles que trabalham com grupos, especialmente para os educadores: professores, coordenadores ou orientadores 
educacionais que trabalham com formação de outras pessoas na sua prática profissional, que, definitivamente, não é dual. Também tínhamos em mente oferecer coordenadas mínimas sobre outros funcionamentos de outros grupos para colegas psicanalistas que, além de conduzirem análises, também ministram seminários, participam de instituições e cartéis.

Tentar fazer uma interface entre esses dois campos foi desafiador e nos forçou a fazer algumas escolhas que resultaram em muitas perdas. Como não nos dirigíamos apenas para especialistas da Psicanálise, optamos por adotar uma linguagem mais accessível dos difíceis conceitos introduzidos pela psicanálise lacaniana. Isso, adicionado à ampliação excessiva do quadro referencial teórico, fez com que em muitas passagens perdêssemos o rigor que gostaríamos de ter tido ao longo desse capítulo.

Como foi preciso introduzir o conceito fundamental de sujeito inserido na linguagem na sua distinção de indivíduo, fomos obrigados a abandonar, nesse capítulo, o estudo mais aprofundado do conceito de autoridade e produção: dois pilares que sustentam os cartéis e os grupos de trabalho. Optamos por abordá-los na segunda parte de forma mais pragmática quando apresentamos os grupos operativos desenvolvidos por Pichon, os grupos de trabalho e de suposição básica estudados por Bion e os cartéis inventados por Lacan.

A escolha de trabalharmos com três autores com práticas distintas de grupo nos obrigou a realizar alguns descentramentos. Nem todos tinham o mesmo olhar sobre os mesmos fenômenos, portanto, os abordavam por diferentes aspectos. Utilizando a metáfora do grupo como estrela, sugerida por Néri, cada um ocupava para nós uma ponta da estrela, examinava o grupo, o nosso objeto de desejo, nosso objeto a, com um determinado referencial e em conformidade com as suas convicções.

Respeitamos as suas elaborações e acreditamos que esse olhar múltiplo nos auxiliou na interpretação de alguns dados na parte prática atendendo o objetivo da nossa proposta: um estudo comparativo e ajudando nas reflexões que pretendemos fazer após expormos a estrutura e as vicissitudes que se apresentaram ao longo desse percurso.

Estávamos advertidos de que a utilização de diferentes referenciais para a análise de um determinado fenômeno poderia gerar inúmeras distorções na percepção e na teoria. Preferimos correr o risco. Interessava-nos aprender com os outros campos e outras abordagens.

Para evitar maiores equívocos, evitamos referências secundárias e recorremos às fontes diretas, os escritos dos próprios autores. Estávamos atentos às brechas e a composição discursiva que utilizavam. Evidentemente, dialogamos com eles utilizando os nossos referenciais, que foram apresentados na primeira parte. Descobrimos coisas interessantes. 
Na terceira e última parte, realizamos uma experiência de cartel com jovens de 11 a 14 anos. Sabíamos que estávamos trabalhando em um campo inteiramente desconhecido. Afinal, não tivemos acesso a nenhum estudo que tivesse realizado uma experiência com o cartel fora do campo onde ele originalmente se inscreve: o da formação de analistas.

Uma primeira experiência de aproximação com o dispositivo teve que ser realizada, já que a instituição que acolheu a nossa proposta não era atravessada pela Psicanálise e as pessoas contatadas para desenvolvermos o trabalho investigativo desconheciam o funcionamento de cartel. Alguns impasses no percurso que demandaram alterações na estratégia.

Excessivos cartéis não funcionavam muito “bem”. Inicialmente suspeitávamos que se tratava da oferta do dispositivo a pessoas muito jovens. Isso nos levou a estudar o conceito de adolescência. Vimos que havia demasiado personalismo nesse campo tal como encontramos nos grupos.

Mais uma vez recorremos a estudiosos e encontramos o trabalho de Alberti, que como nós, entendia a adolescência discursivamente e não como um conceito psicanalítico. Trabalhamos minimamente esse ponto já que o foco do nosso estudo era o funcionamento dos cartéis, não as pessoas que neles se engajavam.

Vimos que para a Psicanálise o sujeito do inconsciente não admite predicação, portanto, ele não envelhece, ele é um efeito do discurso. Essa é uma posição ética, nada retórica, que a Psicanálise introduz na civilização, que desejávamos manter na nossa investigação, ou seja, há a impossibilidade de todos nós, adolescentes ou não, escaparmos do mal-estar e da realidade não ser enganosa. Entendendo dessa forma o estar no mundo, não justificava interrompermos a experiência porque aqueles jovens ainda não "estavam prontos" para experimentar um cartel.

Preferimos adotar uma outra perspectiva para avaliar os disfuncionamentos do dispositivo. Verificamos que havia uma inversão na demanda que precisava ser corrigida. Fazia-se a oferta de investigação através de um cartel, portanto alterava-se a lógica do desejo inerente ao dispositivo.

Vimos que "por se ocupar indefinidamente com as demandas e não verificar o seu desejo, o sujeito neurótico tem a pior dívida consigo mesmo, enganando-se ao afirmar que suas demandas ao Outro correspondem ao seu desejo. Isso é um engodo que o jovem, mais do que qualquer outro, rapidamente percebe". 
Sem saber, esses jovens já estavam nos ensinando, na prática, aquilo que já sabíamos na teoria, e que não aplicamos nesse estudo no primeiro momento. Certamente a oferta do cartel precisava ser feita, pois é ela que gera a demanda, mas a formação, a transformação inerente ao processo de escolha de uma questão até a queda do objeto com a escrita de um texto, vimos que só pode se dar, mesmo que minimamente, se houver o desejo de cada um implicado na sua questão.

Corrigida a rota, restaurávamos a lógica de declaração de cartéis presentes nas instituições psicanalíticas. Uma forma de implicação na instituição com a sua questão, com o seu desejo. Os jovens lá participam no turno oposto ao da escola, de atividades recreativas e culturais e o cartel se incluiu nesse conjunto, por um tempo, como uma oferta possível para os que desejassem. Nesse ponto terminamos a apresentação da estrutura desse estudo e abrimos as consequiências que percurso nos apresentou, tentando avançar com os pontos minimamente já introduzidos Esperamos possam contribuir com reflexões nos dois campos contemplados: educacional e psicanalítico.

Pudemos ver nesse percurso que Pichon entendia o sujeito como social e que, como tal, deve ser analisado no cotidiano nas relações que estabelece com as pessoas e com os papéis que ocupam nos grupos. Com essa perspectiva ele se afastava do nosso olhar do sujeito do inconsciente, que "não pensa" e que é efeito de linguagem. Não discordamos de que pessoas, indivíduos, sejam depositários da ansiedade familiar ou grupal e possam ocupar papéis funcionais nos grupos, como os que ele cita, de "porta-voz", "bode expiatório" ou "aluno problema", entretanto pensamos que podem ser entendidas como posições discursivas e não como um indivíduo ocupando papéis apenas, o que gera graves conseqüências e preconceitos.

Sua proposta de trabalho para operar mudanças e transformações dessas "redes estereotipadas", apesar de ter uma metodologia muito sistematizada, aponta para o que estamos querendo dizer: "abrir o círculo vicioso e estereotipado nas redes de comunicação", para ele "através da empatia e da alteridade entre os integrantes reunidos em torno de uma tarefa"e para nós "com acolhida e escuta do diferente", já que vimos que a natureza do sujeito é falha, ele emerge entre um significante e outro, que o significante não pode cumprir o que promete, não é idêntico a si mesmo, portanto, não há empatia ou alteridade possível. O que isso pode ensinar aos educadores? Que não devem mais se importar com seus alunos? De maneira alguma.

Gostaríamos de introduzir nesse campo mais aberturas e menos universalidade. Pensamos que as explicações podem ser buscadas na rede simbólica que é, por natureza, 
sujeita a muitos equívocos, e nas imagens que fazemos das pessoas, que estão sempre sujeitas a inúmeras distorções. Nessa lógica, cada personagem da cena pedagógica não é um individuo biológico apenas, mas alguém sujeito a uma "rede multidirecional, de modelos internos construídos ao longo da vida" ou como preferimos "rede de significantes" constituídos pela relação com outros semelhantes e o Outro da cultura. Se o "desejo"de empatia e alteridade, pode operar alguma mudança, talvez seja por forçar um deslocamento "de si", do seu narcisismo, para ver um pouco melhor o outro.

De que maneira esse olhar, pode contribuir para o campo psicanalítico, que também concerne a essa pesquisa? Inicialmente pensamos que a contribuição que o estudo desse autor pode dar ao campo psicanalítico não é da ordem discursiva, mas social, já que vimos, existe um valor da experiência coletiva na formação do psicanalista.

É recorrente encontrarmos nos documentos e textos de colegas, referências à iniciativa e de solidariedade como os eixos vivos dessas comunidades. A referência a estes princípios "reforça a implantação dos dispositivos de Escola: passe, cartel e controle que vinculam, de acordo com a sua função, a vertente específica e a vertente comunitária da relação com a causa analítica”. (GOMES, 2008).

Deixemos em suspensão, nesse estudo, os dois outros dispositivos, o passe e o controle, e tomemos apenas o cartel, com o seu caráter eminentemente coletivo, para reflexão. Nesse ponto do estudo, mais ainda do que em outros, apenas introduziremos questões. As referências à solidariedade e à iniciativa reforçam a implantação dos dispositivos com relação à causa analítica: a transmissão da Psicanálise em intenção e extensão. Entretanto, o cartel, lugar privilegiado da coletividade da Psicanálise, não acontece facilmente em muitas instituições psicanalíticas.

Documentos analisados apontam que os mais jovens se aproximam da instituição através dele, mas que quando estão mais familiarizados, abandonam sua prática; muitos participam de cartéis propedêuticos, que cumprem uma função especifica de ajudar na transmissão de alguns conceitos para os que se aproximam da Psicanálise, mas que não se mantém estável como demanda.

Por outro lado, sabemos que existe uma grande oferta de seminários, redes de pesquisa; cursos de fundamentos, grupos organizados ao redor de um ou dois mestres que podem propagar a submissão e raramente convocar o trabalho, pela sua própria composição. Sabemos que não há como se fazer "conhecer" e "reconhecer" numa "multidão". Diante disso, "qual laço social que se pode engendrar no momento em que a única participação dos 
indivíduos que praticam a Psicanálise se dá pela via do reconhecimento social?”. (DUNKER, opus.cit. p.78).

Lacan inventou os cartéis, um pequeno grupo, para a transmissão da Psicanálise e para a formação dos analistas. Ele queria que os cartéis acontecessem de forma mais estável na sua Escola, entretanto, não viu isso acontecer. Pichon decanta da sua experiência que a situação em grupo é o melhor recurso para ensinar a Psiquiatria e criou uma Escola de Psicologia Social com esse fim.

Verificamos que existe um valor social na formação para esses dois autores que passa pelos grupos e que não pode ser desprezado, nesse estudo. Para os dois, de formas distintas, estava em questão que o ato de "ensinar" e "aprender" é um ato de inquirir, indagar ou investigar e que deve acontecer na situação grupal. Algo da transmissão que deve ser pensado como uma estrutura, mais do que uma relação intersubjetiva entre duas pessoas. (VOLTOLINI, opus cit. 2007). O que acontece, então, que essa transmissão não se dá de forma mais estável na Escola?

Uma primeira tentativa de considerar essa questão é pensar que os psicanalistas também não estão imunes aos efeitos imaginários estudados no primeiro capítulo. Vimos que é inevitável que o grupo, lugar privilegiado do desejo, mobilize mecanismos de defesa do Eu e gere angústia, principalmente, no caso dos cartéis, onde se tem que gerar um "produto próprio" ao final. Para lidar com essas forças imobilizadoras, que dificultam a realização da tarefa, Pichon desenvolveu as "leis básicas" da técnica de grupo, e o seu instrumento, o ECRO, e os aplicava em qualquer setor de investigação.

Pudemos ver que a tarefa do coordenador para aliviar a ansiedade é de ajudar os membros do grupo a pensar utilizando técnicas que consistem em criar, manter ou fomentar a comunicação. Com isso rompem-se os estereótipos, reduzem-se o nível de ambigüidade, o mal-entendido e se favorece o vínculo. A tarefa é do grupo, mesmo que seja a formação de cada um que esteja em jogo, como a formação do psiquiatra, do psicólogo social ou do coordenador de grupo operativo.

No cartel a tarefa não é do grupo, é de cada um e, para o mais-um, não são fornecidas “técnicas" para aplicar. À pessoa que ocupa esse lugar, cabe a difícil função, a ser executada sem "manual de instruções", de velar pelo "bom funcionamento" do grupo, ou seja, estabilizar o conjunto, tal como o quarto aro do nó borromeano; reduzir os efeitos imaginários e levar o grupo à produção de um trabalho escrito, produto próprio de cada um. Isso não é pouco, se levamos em conta todas as linhas de forças presentes em um dispositivo. 
Por outro lado, no cartel, também não existe "favorecimento do vínculo para reduzir o mal-entendido que gera ansiedade", porque se parte do principio que a ambigüidade e o equívoco são próprios da linguagem e do dispositivo. Também nele não podemos recorrer ao vínculo, que estabelecido no campo das identificações imaginárias, é algo que a "máquina" precisa combater - com a dissolução em um tempo programado - por propagar ilusões.

Como se isso não fosse pouco, se faz uma exigência ainda mais difícil de ser cumprida na maioria dos cartéis: escrever um texto. Vimos como a escrita mobiliza resistências naquele que escreve, por ser o que há de mais próprio e o que toca mais no impossível. Isso posto, não estaríamos colocando exigências grandes demais para um grupo pequeno? Continuemos refletindo, pois esse é o nosso objetivo com esse estudo, e, vale a pena repetir para reduzir os equívocos, que inevitavelmente possam surgir nesse percurso.

Nessa análise, precisamos levar em consideração que, mesmo os analistas mais "descolados", estão sujeitos aos efeitos da linguagem. Sabemos que não se fica "livre" do sintoma ao final de uma análise, aprende-se a duras penas a lidar com ele. Ademais, o cartel ocupa um lugar ambíguo na Escola, se particular a ela, e aos analistas que se reúnem sob sua insígnia, coletivo, por implicar pessoas que não pertencem ao conjunto e às vezes nem praticam a análise. Como lidar com a ansiedade desses, que ainda podem, sem problemas, estar "mais colados" as insígnias do Outro?

Para Pichon, para ser um grupo operativo, ou seja, para se obter mais produtividade, há necessidade de se trabalhar com a maior heterogeneidade possível de membros, com maior homogeneidade na tarefa. Por tratar-se de grupos formativos, quanto maior a diversidade, maior aprendizagem. Através do uso da escala de avaliação básica o coordenador analisa os fenômenos de identificação, de cooperação, de pertinência ao montante da tarefa, da comunicação, da aprendizagem e do "clima" do grupo, até que se consiga a pertença dos membros ao projeto e se planifique uma ação.

Entretanto, ele constata que na maioria dos grupos, se não na sua totalidade, em um determinado momento, tudo é feito "como se" estivesse executando a tarefa. Existe uma dissociação entre o pensar, o sentir e o agir que é mobilizada pela resistência a mudança e que funciona como obstáculo epistemológico, dificultando a realização do projeto.

Vimos no capítulo anterior e em textos institucionais recentes que o projeto da Escola de Lacan não se realizou. Existem indícios da escassez de cartéis e de suas produções. Poderíamos arriscar pensar que estaríamos na pré-tarefa, como definida por Pichon, agindo 
“como se" o cartel fosse o órgão de base da Escola e o principal responsável pela formação dos analistas?

Poderíamos ser objetados que a Escola não visa "produtividade", entretanto desde 64 já constava desse projeto a produção de um trabalho escrito e que "a pior objeção que se pode fazer às sociedades da forma existente é o esgotamento do trabalho, manifesto até na qualidade, que eles causam nos melhores. $\mathrm{O}$ êxito da Escola se medirá pela publicação de trabalhos que sejam aceitáveis em seu lugar".

Sabemos que os analistas escrevem bastante e publicam também. Mas o quanto dessa publicação é produto de um trabalho em cartel? Cabe analisar as coisas como elas se apresentam, confrontá-las com nossos esquemas referenciais, com a idéia de enriquecê-lo, sem "sermos vitimas das nossas próprias ideologias ou de nossos pensamentos prévios". Parece-nos uma obrigação ética que faz o saber avançar.

Notamos que nos grupos-operativos e nos grupos de trabalho desenvolvidos por Bion não se tinha que escrever um texto ao final de um determinado tempo: dois anos no máximo. Em contrapartida, esse é um procedimento freqüente no campo universitário. Sabemos que Lacan passou pela Universidade, escreveu uma tese, e esse foi o percurso de muitos. Alguns se submeteram às fortes exigências da Escola Normal Superior e todos os que já passaram pela experiência de escrever uma monografia, uma dissertação ou tese sabem que passar por essa experiência não é sem efeitos.

As pesquisas recentes realizadas no campo educacional apontam para os riscos que se corre quando se aplicam os conhecimentos de um campo ao outro, sem a devida mediação. Vimos que a Psicanálise foi introduzida em muitos campos do saber como um sistema teórico passível de ser aplicado. Hoje constatamos os equívocos dessa aplicação. Estaria a Psicanálise aplicando procedimentos educacionais no seu campo também sem as devidas mediações? Estaríamos "importando procedimentos" do campo vizinho? Psicanalistas muitas vezes ao organizarem programas de ensino, ocupam lugares de "professores", ministram cursos, sem terem estudado metodologia ou didática, por exemplo, sem dedicarem tempo às vicissitudes desse outro campo.

Um outro ponto a ser considerado é que Lacan concebeu e defendeu o cartel como órgão de base da sua Escola. Entretanto, nos documentos investigados não encontramos nenhuma referência que Lacan tenha participado de muitos cartéis para deles decantar a experiência. Em 1980, aprimorou seu funcionamento, manteve a exposição de resultados e crises de trabalho; o sorteio e a permuta e acrescentou um limite ao número de participantes e 
a necessidade da produção escrita. Viveu apenas mais um ano, sem poder ver os resultados da sua invenção.

A entrada para a Escola, um outro ponto a se destacar, não se dá necessariamente pelos cartéis, como ele idealizou. Vimos que muitos analistas podem pertencer ao conjunto participando de seminários, redes de pesquisa, etc. Poucas instituições lacanianas consultadas nesse trabalho priorizam ou exigem o trabalho realizado nesse pequeno grupo como porta de entrada ou mesmo fazem da participação num cartel requisito mínimo para pertencer à instituição.

Em contrapartida, verificamos que na Escola de Psicologia Social concebida por Pichon, não há opção: participar de um grupo operativo é a única formação possível. Nas instituições consultadas para esse estudo, alega-se que ele escreveu muito pouco e que, a transmissão do que concebeu sobre os grupos operativos, só pode se dar na prática. Contrariamente, Lacan ministrou muitos seminários, deixou alguns escritos, na sua grande maioria, cifrados a ponto de tornarem-se enigmas fazendo com que os que se inscrevem no seu conjunto passem muito tempo tentando decifrá-lo. Será que foi essa a transmissão deixada por Lacan, a do retorno a Freud, lendo-o linha por linha e levando para céu-aberto as suas reflexões? Será que é isso que se reproduz nas instituições herdeiras do seu estilo, indo na contramão do instrumento que criou? Ou existe algo disfuncional no dispositivo do cartel? Cuidemos por hora do que se transmite.

Verificamos que o cartel é um pequeno grupo de pessoas que se reúne para realizar um estudo. Esse é o seu ponto de partida, mas não é o ponto de chegada, ou seja, a tarefa que cada um terá que realizar individualmente que não é sem efeitos para a estrutura e para o sujeito $\mathrm{O}$ que haveria de formativo nesse processo? O conceito de formação implica em um processo aberto de constante transformação. Ao implicar uma pessoa no seu desejo a sua questão, levála até a escrita de um texto, à sua autoria, é uma experiência formativa, pois transforma a relação do sujeito com o saber e com o fazer. (DUNKER, opus cit, 76-7).

Esse processo de formação e transformação não vai sozinho sem o outro, por isso esse trabalho deve ser realizado em grupo. É a sociabilidade exigida na Psicanálise e na educação. Muitas vezes aprende-se mais com quem não tem a pretensão de ensinar, nem sabia que estava ensinando. Outras vezes, se aprende com uma frase feita aleatoriamente. A questão de uma pessoa no cartel pode disparar um interesse ainda não imaginado no outro e isso é movimenta a trama discursiva, promove rupturas e mudanças na estrutura, que para nós sabemos é discursiva. 
Nessa multiplicidade de linhas de forças inerentes aos dispositivos e a linguagem, é difícil estabelecer de quem é a autoria por que ela sempre depende do outro. Voltolini nos lembra que Freud embora fundador, não deixa de indicar, de um modo bem particular, a implicação em suas próprias formulações teóricas, daquilo que recebeu de seus mestres e como chegou, a partir disso, a "criar" a Psicanálise; "para além das razões pessoais de Freud parece evidente que continuar atribuindo a procedência da idéia a alguém provém da necessidade de admitir que não se teria chegado a ela sem a participação deste outro". (opus cit).

Vimos com Dunker que todo o projeto da lógica do coletivo surge na obra de Lacan no Contexto da Segunda Guerra Mundial, 1945, período em que passou seis semanas na Inglaterra. No texto escrito nesse período,em que Lacan relata essa experiência, vimos a forte impressão que ele teve do trabalho e da postura de Bion. "Nele reencontro a impressão de milagre dos primeiros avanços freudianos: encontrar no próprio impasse de uma situação a força viva da intervenção". Destacamos aí a função "transferencial" de todo conhecimento, um "laço" sempre "particularizado" com o outro. Mas por que no grupo?

Inicialmente vimos que o que foi transmitido foi significante trabalho, presente nos grupos conduzidos por Bion e na regulação do cartel. Entretanto, pensamos que, mais do que esse significante que condensa colaboração, análise racional da realidade, realização de uma tarefa o que também se transmitiu de uma experiência a outra, concerne ao que atribuímos do poder formativo em grupos, particularmente os cartéis: "a cura do outro não é responsabilidade minha, só sou responsável pela minha própria cura e pelo meu sintoma" Bion dizia sem responder à expectativa que lhe colocavam como "autoridade" sintetizada na frase.

Isso é formativo para todos em qualquer grupo. No cartel, implica-se cada um com o seu nome próprio e daí se extraem as conseqüências inclusive para o mais-um. Arriscamos dizer que a escrita de um "produto próprio" é no que consiste o caráter formativo presente nos pequenos grupos, especialmente os cartéis. Cada um tem que se responsabilizar sobre o seu produto, sua autoria, seu objeto, que terá que colocar no mundo e deixar cair tal como o objeto a no final de uma análise. Mais uma vez isso não é sem efeitos.

A posição de Bion não era dogmática, nem visava à uniformidade, "cada um que encontre o seu vocabulário, isso pode servir para eles, mas não para mim”. Fragmentos que descobrimos no texto dos dois autores que nos serviram como pistas discursivas, que 
marcavam, ao menos para nós, o traço de filiação na proposta dos cartéis e demonstravam o poder da transmissão.

Menos do que colocar em questão quem é o pai da Psicanálise, ou quem é o pai do cartel, que na verdade pouco importa, pois sempre que os "filhos" são colocados no mundo, eles ganham o mundo e pai nenhum tem controle no que isso vai dar; interessa-nos mais, avaliar a força de transmissão através de laços transferenciais grupais. Ponto de interseção nos dois campos contemplados nessa pesquisa.

Nos grupos de trabalho da Clínica Tavistok, a tarefa era realizada pelo grupo e as conseqüências eram sentidas no seu funcionamento e nas pessoas individualmente. A posição de Bion introduzia nesse campo, e no dos que educam, a questão ética de que "a melhora dos que cuidava não era sua responsabilidade", sem entender isso como indiferença, pois não é disso que se trata". ${ }^{17}$

Vimos que o grupo de trabalho enquanto atividade mental dirigida à solução de problemas implica em colaboração, abordagem racional. Nesse funcionamento, a aprendizagem pela experiência, é facilmente aceita. Um grupo de trabalho não é um conjunto de pessoas reunidas para trabalhar. Bion aponta que qualquer grupo que funcione como essa abordagem racional pode resvalar para reações primitivas, as suposições básicas de: acasalamento, dependência ou luta-fuga, que demonstram horror ao desenvolvimento, e geralmente emergem nos grupos quando as pessoas fracassam em atingir a tarefa ou diante de uma atitude questionante do líder.

Entendemos que esse ponto e os anteriormente destacados possam contribuir para reflexões nos dois campos: o educacional e psicanalítico. Nosso objetivo nessa parte não era de fornecer respostas fechadas e conclusivas. Interessava-nos estudar o que diferenciava o funcionamento nesses grupos quanto: ao papel a autoridade; os objetivos o trabalho do grupo e a produção. Procuramos pontos de aproximação, encontramos alguns. Verificamos os pontos que os distanciava e aprendemos muito com esse exercício. Esperamos que o nosso leitor imaginário também possa se beneficiar. Sabemos que cada leitura é sempre parcial, ela está sujeita a crítica e a abordagem que cada um faz pela "sua própria janela" perceptiva. Mas ainda temos uma pergunta que não quer calar? Por que então esse dispositivo aparente "bom" para transmissão e formação não se dá de forma mais estável na Escola? Nesse estudo, só

\footnotetext{
${ }^{17}$ Vimos que ele disse numa entrevista que a única coisa que podemos recomendar aos que educam é a "capacidade de amor ardente". O tema do amor apareceu em Freud, Bion e Lacan, que abre para nós um campo de interesse e de investigação. Qual o amor em questão que está sendo recomendado aos que educam? Um outro projeto.
} 
temos os cartéis realizados em outra escola para analisar. Vejamos o os jovens e esses cartéis podem nos ensinar.

Vimos que o dispositivo é como uma espécie de novelo ou meada, "um conjunto multilinear, composto de linhas de natureza diferente que não abarcam, nem delimitam, sistemas homogêneos por sua própria conta, linhas que seguem direções diferentes e formam processos sempre em desequilíbrio". Linhas que tanto se aproximam, como se afastam umas das outras. Não se contentam apenas em compor um dispositivo, mas atravessam-no, arrastam-no, de norte a sul, leste a oeste, na diagonal.

Constatamos nesse estudo que existem em todos os dispositivos, uma colocação em comum de imagens interiores e das angústias dos participantes. Verificamos que os cartéis do segundo movimento foram formados com pessoas com posturas "mais parecidas" e que os "mais bagunçados" e "desinteressados" foram naturalmente excluídos dessas novas organizações. Os jovens se agrupavam por afinidades, identificações imaginárias, e só depois escolhiam o tema geral, identificação a um traço, e muito tempo depois o tema individual, identificação ao objeto de desejo.

Nossa experiência aponta que a dificuldade de encontrar uma questão, não é uma exclusividade dos cartéis formados no CJ. Verificamos a mesma dificuldade nas instituições psicanalíticas e nas escolas. Pensamos que não há como perguntar, sem se "desmascarar", já que a pergunta está ligada ao objeto a, objeto de desejo. Isso pode favorecer a resistência e propiciar uma inibição para todos, psicanalistas, professores ou alunos.

A diferença verificada nos grupos do CJ das demais experiências dos cartéis institucionais reside no fato de que, na maioria das vezes, é a identificação com um tema, a um traço, que dá a partida para a constituição de cartéis nas instituições psicanalíticas. Mesmo não se tratando de uma identificação imaginária, a identificação a um traço, como vimos é sempre uma identificação ao objeto do desejo do Outro. O que dificulta ainda mais a arrumação do conjunto, manifestada em frases tais como: “o cartel é uma coisa fácil de dissolver, mas muito difícil de formar".

Supostamente todos que trabalham em grupo, têm um interesse em comum, essa é a própria definição de grupo. Imaginamos que por estarem na mesma situação, isso predisporia que se mostrassem cooperantes, unidos, benevolentes, solidários, atuando apenas como um grupo de trabalho. Mas não é isso que acontece, não foi isso que vimos. Não há harmonia possível e verificamos nesse estudo que não só a dimensão de visibilidade nos dispositivos 
que oferece distorções. Mas também a dimensão da fala e as linhas de força podem contribuir para isso.

Vimos no capítulo um que as curvas de enunciações (máquinas de fazer falar), não são sujeitos nem objetos, são curvas nas quais se distribuem as posições diferenciais dos seus elementos, são enunciações que distribuem variáveis, regimes de enunciações que definem uma ciência, em um determinado momento, um gênero literário ou um movimento social, por exemplo. Regime que precisa ser definido em função do visível e do enunciável, com suas derivações, suas transformações, suas mutações que nós arriscamos aproximá-las do simbólico.

Destacamos da fala de uma das jovens um fragmento que demonstra discursivamente as possibilidades de deslocamentos de assuntos, de opiniões, de posições. Ela foi atravessada pela questão da diferença entre os que "podiam" e os que "não podiam" participar dos cartéis. Após discussão no grupo, uma semana depois traz novas informações sobre o tema."Pesquisei a diferença nos cérebros das pessoas mais jovens e mais velhas, chegando à conclusão que os atos são diferentes, mas que o funcionamento é igual. Eles pensam, sofrem, têm medo como todo mundo".

Essa frase surgiu após longo debate sobre o tema. Movimentações discursivas assim nos grupos, muitas vezes, são difíceis de acontecer. Nos cartéis que tivemos oportunidade de participar elas aconteceram pouquíssimas vezes. Mas, orientados pela lógica dos dispositivos e da linguagem, apostávamos que, na cadeia discursiva, novas rupturas podiam surgir. $\mathrm{O}$ exemplo que encontramos para ilustrar destaca-se ainda da fala dessa jovem: "sei que este não é o tema da nossa pesquisa, mas fiquei curiosa", Falas que emergem no meio de uma sequiência pré-estabelecida, ou numa cadeia significante, tal como o sujeito emerge entre um significante e outro, trazendo o seu estatuto de verdade, por tocarem diretamente no desejo.

Também vimos que outras linhas de forças, além das citadas, compõem um dispositivo, de alguma maneira. São as linhas que "retificam" as curvas anteriores, traçam tangentes, envolvem os trajetos de uma linha com outra linha, operam idas e vindas entre o ver e o dizer, agindo como setas que não cessam de penetrar as palavras e as coisas, que não cessam de conduzir à batalha. Elas são invisíveis e indizíveis, estreitamente mescladas com as outras linhas, mas, entretanto, é indistinguível destas. Trata-se da "dimensão do poder", a terceira dimensão do espaço interno do dispositivo, variável em cada um deles. Esta dimensão se compõe, tanto com o poder, como com o saber. 
Na situação de grupo vivida no CJ, destacamos a função do mais-um, que para eles tinha essa dimensão de poder, invisível e indizível. Mesmo não querendo ocupar o lugar daquele que sabe e tem algo a dizer, era sempre colocado nessa posição, toda vez que fazia alguma afirmação ou mesmo quando ficava em silêncio. Ainda assim, não deixava de fazer a sua tarefa ética "velar sobre os efeitos internos, efeitos de grupo que vimos no capitulo um, e provocar a elaboração, colocar a céu-aberto os seus resultados" e apostar que algo novo podia surgir no final de cada um dos cartéis.

Verificamos que para realizar essa tarefa, às vezes, ele utilizou recursos técnicos como o brainstorming, o estímulo à reescrita, a leitura de um texto sobre "como escrever um ensaio" e em um determinado momento, até atuou como escriba. Entretanto, a sua postura era ética. Do lugar de autoridade do grupo, vimos que relançava para os membros do cartel a se responsabilizarem por um produto de sua própria autoria. Estimulava-os a dizerem um pouco mais a se implicarem com as suas questões. Acolhia, mas não aceitava justificativas tolas que apontassem para a resistência à tarefa e ao desenvolvimento.

Discutimos também na apresentação dos dispositivos que algo faltava ao mapa dos dispositivos compostos por três linhas apenas. Na sua concepção vimos que Foucault, sentia que não podia deixá-los fechar-se em linhas de forças intransponíveis, de contorno definitivo. Pensava que tinha que ser possível transpor a linha de força que fechava o dispositivo, chegar ao outro lado. Afirmou que isso pode acontecer quando a linha de força se volta sobre si mesma, afeta-se a si mesma. Para dar conta disso, definiu as linhas de subjetivação, descobertas em um período posterior.

O si-mesmo não é nem um poder, nem um saber, não é uma determinação préexistente e já acabada. Ele é um processo, uma produção de subjetividade em um dispositivo, ela está para se fazer, na medida em que o dispositivo o deixe ou o faça possível. É uma linha de fuga que escapa às linhas anteriores. É um processo de individuação que diz respeito a grupos ou pessoas, que escapa tanto às forças estabelecidas como aos saberes constituídos: uma espécie de mais-valia. São regras facultativas do domínio de si-mesmo (que constituem uma subjetivação, autônoma) verificáveis no modo grego de funcionar, nas sociedades modernas, por exemplo. Elas implicam em movimento, em instabilidade.

Pudemos ver que essas linhas de subjetivação são um extremo limite de um dispositivo, elas esboçam a passagem de um dispositivo ao outro, nesse sentido elas predispõem as linhas de fratura, ruptura ou fissura. Deleuze exemplifica dizendo que os que se subjetivam são tanto os nobres, "os bons", quanto os excluídos, "os maus", os pecadores, os eremitas ou os heréticos: toda uma tipologia das formações subjetivas, em dispositivos 
móveis. E, por todos os lados, há emaranhados que é preciso desmesclar: produções de subjetividade que escapam dos poderes e dos saberes de um dispositivo para colocar-se sob os saberes e os poderes de outro, em outras formas ainda por nascer. Essa é a característica das linhas de ruptura, uma forma possível de lidar com os grupos.

Vimos que a linguagem também apresenta essa dinâmica. Ela aceita a desordem e subverte a lógica clássica. Há equivocação e emaranhados para desmesclar. Acreditamos que entender essa lógica pode ser uma contribuição importante para o campo educacional, onde se buscam técnicas e certezas. Se há duas consequiências importantes para uma filosofia dos dispositivos, e que também podemos levar para os dois campos é, primeiro, $o$ repúdio dos universais, nem todos os cartéis ou grupos funcionarão bem; segundo, que há uma mudança de orientação que se separa do eterno para apreender o novo, variável em cada dispositivo. Donde deduzimos que é preciso haver separação para haver formação.

Com efeito, o universal nada explica, é ele que deve ser explicado. Vimos que todas as linhas são de variação, não têm sequer coordenadas constantes. O Uno, o Todo, o Verdadeiro, o objeto e o sujeito não são universais, mas processos singulares de unificação, de totalização, de verificação, de objetivação, subjetivação, processos imanentes em um dado dispositivo. E cada dispositivo é uma multiplicidade na qual esses processos operam em devir, distinto do que operam em outros dispositivos.

Quanto à segunda conseqüência possível de se extrair de uma filosofia dos dispositivos, vimos que o que conta é a novidade no próprio regime de enunciação que pode compreender enunciações contraditórias - "é a novidade no regime que conta, a novidade do dispositivo da Revolução Francesa ou Bolchevique e não a originalidade da enunciação”. (opus cit). Todo dispositivo se define pelo que detém em novidade e criatividade, o qual marca, ao mesmo tempo, sua capacidade de se transformar ou se fissurar em proveito de um dispositivo futuro.

Afirmamos anteriormente que pertencemos a certos dispositivos e neles agimos. A novidade em um dispositivo em relação aos anteriores é o que chamamos a sua atualidade, nossa atualidade. $\mathrm{O}$ novo é o atual. $\mathrm{O}$ atual não é o que somos, mas aquilo em que vamos nos tornando, o que chegamos a ser, quer dizer, o outro, nossa diferente evolução. Em outras palavras, a história é o arquivo, o que somos e deixamos de ser, enquanto que o atual é o esboço daquilo que vamos nos tornando. Dizendo ainda de outro modo, história nos separa de nós próprios e o atual é esse outro com o qual já coincidimos.

Aprendemos com a Psicanálise, orientada pelo inconsciente estruturado como uma linguagem opera alterações no discurso. Vimos também que através da alienação e separação 
o sujeito se constitui. Todos alienados aos significantes e ao desejo do Outro recebem através da linguagem as normas, regras, moral. Através dela podem se desembaraçar dos seus sintomas, abrir sua rede significante e operar novas arrumações. Entretanto a experiência mostra que isso não acontece sem o outro, sem o analista nas análises individuais, sem o mais-um nos cartéis, sem os professores nas salas de aula e sem os coordenadores e orientadores nos cursos de formação.

Vimos com Costa que se as pessoas fossem deixadas à margem da sociedade, ficariam entregues "às forças cegas da libido", funcionando em regime de onipotência narcísica, inermes e desamparadas, por sua impotência biológica. Totalmente entregues à pulsão, não seriam marcadas pela linguagem, pelo recalque, não receberiam sua herança cultural através das "insígnias do Outro", por fim, não conseguiriam conviver em grupos.

A escola, além da família, ocupa esse lugar do Outro, "tesouro do significante", traços da cultura que precisam ser transmitidos. O professor é o veículo e os alunos receptores. Eles afetam, mas também são afetados, num processo de "reconhecimento mútuo" como o introduzido pela dialética hegeliana. Desta destacamos os quatro estágios apontados por Hegel para se sair da servidão. Estágios marcados por crises da autoridade que, como vimos, ocorrem através da descrença naquilo em que antes se acreditou.

Falando de uma forma diferente do que já dissemos, o "professor" - aqui tomado nos dois campos já que o analista também "ensina"-, depende do aluno para a produção do seu prazer, que pode ser a demonstração do seu conhecimento e sua habilidade na transmissão. É verdade que um professor pode fazer o aluno tirar nota baixa, pode maltratá-lo, humilhá-lo por não ter conhecimento no tema que o professor domina. Certamente isso lhe trará um "prazer sádico", mas é o que o aluno produz, o trabalho feito por ele, seja um artigo, uma boa nota, a escuta atenta às aulas, que fornecem meios de prazer para o professor.

$\mathrm{O}$ primeiro passo para sair da servidão, seguindo a dialética hegeliana, é quando o aluno toma consciência do que realmente é e do prazer que o seu trabalho e sua atitude produzem no professor. Depois deste, vem o estágio estóico, aquele cujo aluno começa retirando-se do mundo para seus próprios pensamentos. No estágio seguinte, o ceticismo, ele volta-se para o mundo e ainda um servo obediente, descrê do papel que desempenha e da superioridade moral do professor.

A consciência infeliz, terceiro estágio, internaliza esse conhecimento cético sobre uma relação social: existem um professor e um aluno em todo ser humano. Aprendemos que Hegel chama essa consciência infeliz de "consciência do eu como um ser de natureza dupla, 
meramente contraditório". Na consciência relacional essa triste cisão que cada pessoa vê em si mesma, é vista nos outros, esse conhecimento volta a se socializar.

Nesses dois últimos estágios, vimos com Sennet, que o senhor perde seu poder sobre o seu escravo, não porque o escravo tome seu poder, ou o derrube, mas porque ele se tornou uma pessoa diferente, aprendeu a lidar de uma maneira não competitiva com o senhor e isso obriga este último a modular o seu próprio comportamento. No nosso exercício de transposição de campo, arriscaríamos dizer: "o professor" perde o seu poder sobre o aluno, não porque o aluno tome o seu poder ou o derrube, mas porque ele aprendeu a lutar de forma não competitiva com a autoridade. Essa lógica pode também ser transposta para os cartéis e para as escolas nos dois campos.

Aqueles que nele se engajam em um cartel, muitas vezes vêm na posição de "escravos", querem "um senhor" que lhes ensinem sobre algo. Todos condicionados ao jogo significante, à linguagem desde antes do seu nascimento e para além da morte, estão presos, servos da cadeia simbólica. Entretanto, se tudo correr bem, logo no primeiro lance, encontram um "senhor advertido", que sabe que o saber está do outro lado e que pode ajudar no "processo de libertação" implicando cada um com a sua questão. Entretanto, a implicação na produção, a possibilidade de surgimento de um significante novo, a ampliação da rede multilinear, pode ser ameaçadora para muitos; paralisante para alguns, mas estimulante para outros. Estamos na lógica do "não-todo".

Para nós, as metáforas introduzidas nesse estudo sobre o grupo como um envelope com um dentro e um fora; ou como um círculo onde todos ocupam posições de igualdade; ou como uma máquina ou um organismo vivo, não nos parecem apropriadas para dar conta dessa complexidade. Elas são metáforas carregadas de grupalidade que não abrem espaço para as rupturas, para o incompreensível inerente a esses dois campos. Deste modo, argumentamos nesse estudo a favor do nó borromeano como escritura que melhor representa o sujeito e o grupo; e do conjunto multilinear, inerente à estrutura dos dispositivos, para melhor representar o que acontece no cartel e na linguagem.

Como o Todo, o Uno, o Verdadeiro e o sujeito não são universais, entendemos que melhor do que negar a complexidade inerente à estrutura das pessoas e dos grupos, mais produtivo é aprender a lidar com elas. Não há harmonia possível na natureza, nem nos agrupamentos humanos. Existem forças poderosas e destrutivas dos dois lados, que se adequadamente manejadas, podem causar "menos estragos". Um professor, um psicanalista, um educador que tenha conhecimento desta multiplicidade de forças presentes em qualquer conjunto, poderá melhor ligar com as vicissitudes que surgem nos seus campos de trabalho. 
Essa seria a nossa conclusão para esse estudo, mas, como fomos afetados pelo dispositivo e por Blanchot, sabemos que podemos ser objetados, ou encontrarmos resposta melhor, depois de decantada a experiência. 


\section{REFERÊNCIAS}




\section{REFERÊNCIAS}

ABRÃO, J.L. F. As influências da psicanálise na educação brasileira no inicio do século XX. Psicologia: Teoria e Pesquisa. Mai-Ago., 2006. Vol. 22, pp. 233-240.

ALBERTI, S. Esse sujeito adolescente. Rio de Janeiro: Rios Ambiciosos, 1999.

AMADO, J. In: BRITO, J. D. de (org.). Por que escrevo? São Paulo: Nova Editora, 2006.

ANZIEU, D. O grupo e o inconsciente: o imaginário grupal. São Paulo: Casa do Psicólogo, 1993.

APOLLON, W. The discourse of gangs in the stake of male repression and narcissism. In: BRACHER et al (editors). Lacanian theory of discourse: subject, structure, and society. New York and London: New York University Press, 1994. pp.201-219.

BION, W. Conversando com Bion. Rio de Janeiro: Imago, 1992.

Experiências com grupos: os fundamentos da psicoterapia de grupo. Rio de Janeiro: Imago; São Paulo: Edusp, 1975.

CARDOSO, M. R Entrevista com Jurandir Freire Costa. In: CARDOSO, M. R.(org). Adolescentes. São Paulo: Escuta, 2006. pp. 18-23.

COSTA, J.F.C. Psicanálise e contexto cultural: imaginário psicanalítico, grupos e psicoterapia. Rio de janeiro: Campus, 1989.

DARMON, M. Ensaios sobre a topologia lacaniana. Porto Alegre: Artes Médicas, 1994.

DELEUSE, G. ¿Que é um dispositivo? In: BALBIER, E. et al. Michel Foucault, filósofo. Barcelona: Gedisa, 1990. pp.155-161.

DUNKER, Por que 4+1 para o cartel? In: GUATIMOSIN, B. Em torno do cartel. Salvador: Associação Fóruns do Campo Lacaniano, 2004. pp.75-82.

DURET, M.L. A dis-solução de um cartel. In: JIMENEZ, Stella (org.). O cartel. Rio de Janeiro: Campus, 1994. pp.169-176.

ENRIQUEZ, E. De la hord à l'état. Paris: Gallimard, 1983.

FINK, B. Ciência e psicanálise. In: FELESTEINS, R; FINK, B; JANUS, M. Para ler o seminário 11 de Lacan: os quatro conceitos fundamentais da psicanálise. Rio de Janeiro: Jorge Zahar, 1997. pp.68-79. 
FREUD, S., (1908) Moral sexual civilizada e doença nervosa moderna. In: Edição Standard Brasileira das Obras Completas de S. Freud. Rio de Janeiro: Imago, 1980.

- (1912) Totem e tabu. In: Edição Standard Brasileira das Obras

Completas de S. Freud. Rio de Janeiro: Imago, 1980.

. (1914) Sobre o narcisismo. In: Edição Standard Brasileira das Obras

Completas de S. Freud. Rio de Janeiro: Imago, 1980. (1921) Psicologia das massas e análise do eu. In: Edição Standard

Brasileira das Obras Completas de S. Freud. Rio de Janeiro: Imago, 1980. (1927) O futuro de uma ilusão. In: Edição Standard Brasileira das

Obras Completas de S. Freud. Rio de Janeiro: Imago, 1980. . (1929) O mal-estar na civilização. In: Edição Standard Brasileira das

Obras Completas de S. Freud. Rio de Janeiro: Imago, 1980. (1934) Moisés e o monoteísmo. In: Edição Standard Brasileira das

Obras Completas de S. Freud. Rio de Janeiro: Imago, 1980.

FRANCO FILHO, O. Identidade do psicoterapeuta do grupo. In: OSÓRIO, L.C. et al. Grupoterapia hoje. Porto Alegre, Artes Médicas, 1986. pp.21-31.

GOMEZ, M. A, Quarenta anos depois da Proposição de Lacan... o passe ainda. WUNSCH, Boletim Internacional da Escola de Psicanálise dos Fóruns do campo Lacaniano, no. 6, 2007. Disponível em: http//www.vencontro-ifepfcl.com.br Acesso em: 30 de Jan. de 2008.

GONÇALVES, D. Cartel: um pouco de história. In: GUATIMOSIN, B. Em torno do cartel. Salvador: Associação Fóruns do Campo Lacaniano, 2004. pp.69-73.

GUARNIERI, M. R. Tornando-se professor: o inicio da carreira docente e a consolidação da profissão. Tese de doutorado (Metodologia do Ensino). Universidade Federal de São Carlos. 1996.

JIMENEZ, S., O cartel. In. O Cartel, organizado por Stella Jimenez - Rio de Janeiro: Campus, 1994. pp.11-34.

LACAN. J., (1945) O número treze e a forma lógica da suspeita. In: Outros Escritos. Rio de Janeiro: Jorge Zahar, 2003.

(1947) A psiquiatria inglesa. In: Outros Escritos. Rio de Janeiro: Jorge Zahar, 2003.

(1960) Observações sobre o relatório de Daniel Lagache: "Psicanálise

e estrutura da personalidade". In: Escritos. Rio de Janeiro: Jorge Zahar, 1998.

O seminário, livro 9: A identificação (1961-1962). s/d.

Zahar, 2003.

(1964) Ato de Fundação. In: Outros Escritos. Rio de Janeiro: Jorge

Jorge Zahar, 1998.

(1964) A posição do inconsciente. In: Escritos. Rio de Janeiro:

(1966) A ciência e a verdade. In: Outros Escritos. Rio de Janeiro:

Jorge Zahar, 2003.

(1967) A proposição de 9 de outubro de 1967 sobre o psicanalista da

Escola. In: Outros Escritos. Rio de Janeiro: Jorge Zahar, 2003.

O seminário, livro 22: RSI (1974-1975). s/d. 
(1975) D’Ecolage, publicado em Ornicar? (20-21). Editions du Seuil, 1980. In: Lettres de l'École Freudienne de paris, no.18, 1975. In: Letra Freudiana. Ano I, no.0. s/d.

(1975) LUZ! publicado em Ornicar? (20-21). Editions du Seuil, 1980. In: Lettres de l'École Freudienne de paris, no.18, 1975. In: Letra Freudiana. Ano I, no.0. s/d.

(1975) Senhor A. publicado em Ornicar? (20-21). Editions du Seuil, 1980. In: Lettres de l'École Freudienne de paris, no.18, 1975. In: Letra Freudiana. Ano I, no.0. s/d.

(1975) Discussões das Jornadas sobre Cartéis. Lettres de l'École Freudienne de Paris, no.18. In: Letra Freudiana. Ano I, no.0. s/d. O seminário, livro 25: O momento de concluir. (1977-1978). s/d. O seminário, livro 25: O momento de concluir. (1977-1978). s/d. Meu ensino. Rio de Janeiro: Jorge Zahar, 2006.

LEGENDRE, P. O amor do censor: ensaio sobre a ordem dogmática. Colégio Freudiano do Rio de Janeiro. Rio de janeiro: Forense Universitária: Colégio Freudiano, 1983.

MAHJOUB-TROBAS, L. Produto próprio de cada um. In: JIMENEZ, Stella (org.). O cartel. Rio de Janeiro: Campus, 1994. pp.107-124.

MÉNARD, H., Cartel e produto. In: JIMENEZ, Stella (org.). O cartel. Rio de Janeiro: Campus, 1994. pp.101-106.

MELLO, D. M. Nau do desejo: o percurso da ética de Freud a Lacan. Rio de Janeiro: Relume-Dumará; Alfenas, MG: Unifenas, 1995.

MILLER, J.A. Novas Reflexões sobre o Cartel. Correio n. 10. São Paulo: Escola Brasileira de Psicanálise - em formação, 1994. pp.11-15.

MILLOT. C. Freud antipedagogo. Rio de Janeiro: Jorge Zahar, 2001.

MOSCOVICI, S. L’âge dês foules. Bruxelles: Editions Complexes. 1985.

NERI, C. Grupo: manual de psicanálise de grupo. Rio de Janeiro: Imago, 1999.

O'DONNEL, P. La teoria de la transferência em psicoterapia grupal. Buenos Aires: Nueva Vision, 1984.

PAZ, V. Dis-solução: de Maeterlink a Lacan. In: JIMENEZ, Stella (org.). O cartel. Rio de Janeiro: Campus, 1994. pp.177-182.

PICHON-RIVIÈRE, E. Teoria do Vínculo. São Paulo: Martins Fontes, 1987. O processo grupal. São Paulo: Martins Fontes, 1988.

PONTALIS, J.B. Aprés Freud. Paris: Gallimard. Paris, EPI, (41):53-77, 1983. 
ROUDINESCO, E. História da psicanálise na França. Rio de Janeiro: Jorge Zahar, 1988.

SANTOS, L., Psicanálise: uma inspira-ação para psicologia escolar? 2003, 103 pp, Dissertação de Mestrado (Psicologia Escolar), Instituto de Psicologia, USP, São Paulo.

SENNET, R. Autoridade. Rio de Janeiro: Record, 2001.

SILVA, C. A. da. Teorias de grupo em pauta: contribuições ao campo educacional. 2000, 194 pp, Dissertação de Mestrado (Psicologia e Educação), Faculdade de educação, USP, São Paulo.

SILVA, M. O habitus professoral: o objeto dos estudos sobre o ato de ensinar na sala de aula. ANPED Revista Brasileira de Educação, n. 29, Campinas: Editora Autores Associados Ltda, 2005. pp.152-163.

VOLTOLINI, R. A educação como "fato inconveniente" para a psicanálise. Psicanálise, Educação e Transmissão, 6., 2007, São Paulo. Anais eletrônicos. Disponível em: http://www.preceedings.scielo.br/scielo.php?script=sci_arttext\&pid=MSC0000000 032007000100006\&lng=es\&nrm=abn>. Acesso em: 26 de Jan. de 2008.

As vicissitudes da transmissão da psicanálise a educadores. COLÓQUIO DO LEPSI IP/FE-USP, 3., 2001, São Paulo. Proceedings online. Disponível em:: http://www.proceedings.scielo.br/scielo.php?script=sci_arttext\&pid=MSC0000000 032001000300036\&lng=en\&nrm=abn>. Acesso em: 25 Jan. 2008.

VORCARO, A. A criança na clínica psicanalítica. Rio de Janeiro: Companhia de Freud, 2004.

WEIZ, T., O dialogo entre o ensino e a aprendizagem. São Paulo: editora Ática, 2000 . 
ANEXOS 